OPEN ACCESS

Edited by:

Charles Evans Wood, University of Florida, United States

Reviewed by:

Daniele De Luca,

Université Paris-Sud, France

Thomas Thymann,

University of Copenhagen, Denmark

*Correspondence:

Martin F. Krause

martin.krause@uksh.de

Specialty section:

This article was submitted to Embryonic and Developmental

Physiology,

a section of the journal

Frontiers in Physiology

Received: 27 June 2019 Accepted: 10 October 2019 Published: 30 October 2019

Citation:

Spengler D, Rintz N and Krause MF (2019) An Unsettled Promise: The Newborn Piglet Model of Neonatal Acute Respiratory Distress Syndrome (NARDS). Physiologic Data and Systematic Review.

Front. Physiol. 10:1345 doi: 10.3389/fphys.2019.01345

\section{An Unsettled Promise: The Newborn Piglet Model of Neonatal Acute Respiratory Distress Syndrome (NARDS). Physiologic Data and Systematic Review}

\author{
Dietmar Spengler, Nele Rintz and Martin F. Krause* \\ Department of Pediatrics, Universitätsklinikum Schleswig-Holstein, Kiel, Germany
}

Despite great advances in mechanical ventilation and surfactant administration for the newborn infant with life-threatening respiratory failure no specific therapies are currently established to tackle major pro-inflammatory pathways. The susceptibility of the newborn infant with neonatal acute respiratory distress syndrome (NARDS) to exogenous surfactant is linked with a suppression of most of the immunologic responses by the innate immune system, however, additional corticosteroids applied in any severe pediatric lung disease with inflammatory background do not reduce morbidity or mortality and may even cause harm. Thus, the neonatal piglet model of acute lung injury serves as an excellent model to study respiratory failure and is the preferred animal model for reasons of availability, body size, similarities of porcine and human lung, robustness, and costs. In addition, similarities to the human toll-like receptor 4 , the existence of intraalveolar macrophages, the sensitivity to lipopolysaccharide, and the production of nitric oxide make the piglet indispensable in anti-inflammatory research. Here we present the physiologic and immunologic data of newborn piglets from three trials involving acute lung injury secondary to repeated airway lavage (and others), mechanical ventilation, and a specific anti-inflammatory intervention via the intratracheal route using surfactant as a carrier substance. The physiologic data from many organ systems of the newborn piglet-but with preference on the lung-are presented here differentiating between baseline data from the uninjured piglet, the impact of acute lung injury on various parameters $(24 \mathrm{~h})$, and the follow up data after $72 \mathrm{~h}$ of mechanical ventilation. Data from the control group and the intervention groups are listed separately or combined. A systematic review of the newborn piglet meconium aspiration model and the repeated airway lavage model is finally presented. While many studies assessed lung injury scores, leukocyte infiltration, and protein/cytokine concentrations in bronchoalveolar fluid, a systematic approach to tackle major upstream pro-inflammatory pathways of the innate 
immune system is still in the fledgling stages. For the sake of newborn infants with life-threatening NARDS the newborn piglet model still is an unsettled promise offering many options to conquer neonatal physiology/immunology and to establish potent treatment modalities.

Keywords: acute lung injury, pro-inflammatory pathways, immunosuppression, surfactant, mechanical ventilation, meconium aspiration model, lavage model, innate immunity

\section{INTRODUCTION}

Respiratory failure is the leading cause of morbidity and mortality in newborn infants regardless of gestational age. Great advances in the construction of neonatal ventilators (continuousflow) and in the development of assisted ventilation devices (e.g., invasive pressure-limited or volume-constant ventilation, continuous positive airway pressure breathing, nasal high-flow therapy) permitted to push back the thread of futile respiratory failure (Owen et al., 2017). Many years ago respiratory distress syndrome of the premature infant (IRDS) was attributed to a lack of surfactant production in the early stage of alveolar development of the immature lung (Farrell and Avery, 1975).

Abbreviations: AEC, alveolar epithelial cells; Ang-2, angiopoietin 2; ANOVA, analysis of variance; ARDS, (adult) acute respiratory distress syndrome; ASC, apoptosis-associated speck-like protein containing a caspase recruitment domain; aSMase, acid sphingomyelinase; AT III, antithrombin III; BALF, broncho-alveolar lavage fluid; (S/D)BP, (systolic/diastolic) blood pressure; BPD, broncho-pulmonary dysplasia; C, control group; CD14/18/61, cluster of differentiation 14/18/61; CI, confidence interval; $\mathrm{C} 3 / 5 \mathrm{a}$, complement factor $3 / 5$ activated; DOPG, dioleoylphosphatidylglycerol; EMT, epithelial-to-mesenchymal transition; EVLWI, extravascular lung water index; $\mathrm{F}_{\mathrm{i}} \mathrm{O}_{2}$, fraction of inspired oxygen; $\mathrm{FRC}$, functional residual capacity; G-CSF, granulocyte colony stimulating factor; GBS, group B streptococci (Streptococcus agalactiae); HC, healthy control group; piglets not subject to lung injury; HI, heart index; HR, heart rate; HVR, hypervariable region (of Toll-like receptor 4); IFN $(-\gamma)$, interferon $(\gamma)$; IL- $1(\alpha / \beta),-6,-8$, interleukin $1(\alpha / \beta), 6$, 8; IL-1 ra, interleukin 1 receptor agonist; IRDS, respiratory distress syndrome of the premature infant; ITBI, intra-thoracic blood volume index; KC, murine functional chemokine analog of IL-8; LPS, lipopolysaccharide; $\mathrm{LTB}_{4}$, leukotriene $\mathrm{B}_{4}$; MAP, mean airway pressure; MCP1, monocyte chemotactic protein 1; MD-2, lymphocyte antigen 96; MIP-2, macrophage inflammatory protein 2 ; MMP-1/2/8/9, matrix metalloproteinase $1 / 2 / 8 / 9$; MPO, myeloperoxidase; NARDS, neonatal acute respiratory distress syndrome; NF- $\kappa \mathrm{B}$, nuclear factor $\kappa \mathrm{B}$; $\mathrm{NLRP}(3)$, inflammasome nucleotide-binding domain-leucine rich repeat- containing protein-(3); NO, nitric oxide; OI, oxygenation index $\left(\mathrm{MAP} * \% \mathrm{O}_{2} / \mathrm{PaO}_{2}\right) ; \mathrm{PaCO}_{2}$, partial pressure of carbon dioxide; PAI-1, plasminogen activator inhibitor 1; PAMP, pathogen-associated molecular pattern; PAP, pulmonary arterial pressure; PARDS, pediatric acute respiratory distress syndrome; PC, phosphatidylcholine; PEEP, positive endexpiratory pressure; PIM, pulmonary intravascular macrophages; PIP, peak inspiratory pressure; PMNL, polymorpho-nuclear leukocytes; POPG, palmitoyloleoyl-phosphatidylglycerol; PVRI, pulmonary vascular resistance index; rhCC10, recombinant human Clara Cell protein 10; ROS, reactive oxygen species; $\mathrm{R}_{\mathrm{rs}}$, resistance of the respiratory system; $\mathrm{sC}_{\mathrm{rs}}$, specific compliance of the respiratory system; SA/LA, small/large (surfactant) aggregates; sC5b-9, soluble complement factor 5b-9, membrane attack protein; SD, standard deviation; sICAM-1, soluble intercellular adhesion molecule 1 ; SP(-A/B/D), surfactant protein ($\mathrm{A} / \mathrm{B} / \mathrm{D}$ ); $\mathrm{sPLA}_{2}$, soluble phospholipase $\mathrm{A}_{2}$; sRAGE, soluble receptor for advanced glycation end product; SVI, stroke volume index; SVV, stroke volume variation; SVRI, systemic vascular resistance index; T, treatment group; TAT, thrombin antithrombin complex; TGF- $\beta$, transforming growth factor $\beta$; TLR4, Toll-like receptor 4 ; TNF- $\alpha$, tumor necrosis factor $\alpha$; TTN, transient tachypnea of the newborn; VEI, ventilation efficiency index $\left(3,800 /\left(\mathrm{PIP}_{\mathrm{PEEP}} \mathrm{f}^{*} \mathrm{PaCO}_{2}\right)\right) ; \mathrm{V}_{\mathrm{A}}$, alveolar portion of the tidal volume; $\mathrm{V}_{\mathrm{T}}$, tidal volume; vWF, von Willebrand factor.
However, respiratory failure of the term infant secondary to obvious damage of the lungs in the perinatal period, such as meconium, bile, and blood aspiration, lung hemorrhage, pneumonia, or severe chorioamnionitis and sepsis, leading to secondary impairment of surfactant function and surfactant amount, has not been officially defined before 2017 when the Montreux definition of neonatal ARDS (NARDS) was published (De Luca et al., 2017).

The Montreux definition of NARDS requires the following clinical conditions: respiratory failure of acute onset; exclusion of IRDS, transient tachypnea of the newborn (TTN), and congenital malformations of the lung; diffuse, bilateral, and irregular opacities or infiltrates by chest-Xray; lung edema of non-cardiac origin; and an oxygenation deficit expressed by the oxygenation index $\left(\mathrm{OI}=\mathrm{MAP} * \% \mathrm{O}_{2} / \mathrm{PaO}_{2}\right.$, with $\mathrm{MAP}=$ mean airway pressure) being mild (OI 4-8), moderate (OI 8-16), or severe $(\mathrm{OI}>16)$.

Severe inflammation of the lung tissue in adult ARDS (ARDS) patients prompted researchers to investigate the effect of corticosteroids (Bernard et al., 1987; Steinberg et al., 2006; Needham et al., 2014) without being able to proof reduced mortality (except of the study by Meduri et al., 2007). Indeed, a pediatric study involving ARDS patients (PARDS) being subject to corticosteroid treatment showed increased mortality and less ventilator-free days (Yehya et al., 2015) whereas others (Drago et al., 2015; Kimura et al., 2016) could neither show clinical improvements by methylprednisolone infusions nor meaningful changes in plasma biomarker levels comparing methylprednisolone and placebo (e.g., MMP-8, Ang-2, sICAM-1, PAI-1, sRAGE).

In contrast to ARDS (Anzueto et al., 1996; Spragg et al., 2004; Kesecioglu et al., 2009; Willson et al., 2015), NARDS (Lotze et al., 1998) and PARDS (Herting et al., 2002; Möller et al., 2003; Willson et al., 2005) patients profit from their susceptibility to surfactant treatment. As surfactant is able to mitigate many components of lung inflammation (Kunzmann et al., 2013) its use may be universally indicated together with adjuncts specifically tackling pro-inflammatory pathways being central for lung inflammation. Thus, the pharmacologic armamentarium in the treatment of NARDS appears to be more variable and may be applied more individually than the classical immune-suppressive means in respiratory disease of children (i.e., corticosteroids) (de Benedictis and Bush, 2012).

The identification of major pro-inflammatory pathways [by the analysis of serum or broncho-alveolar lavage fluid (BALF)] causing respiratory failure in NARDS/PARDS has so far brought preliminary results only: De Luca et al. identified secretory phospholipase A2 secreted by alveolar macrophages as the 
main reason for surfactant degradation (De Luca et al., 2008) whereas in PARDS the analysis of serum Ang-2 and vWF yielded equivocal results (Kimura et al., 2016; Zinter et al., 2016), and the analysis of interleukins, IFN, MCP-1, G-CSF, and MMP-8 did not reveal any pathway-typical patterns (Kimura et al., 2016; Schwingshackl et al., 2016). As an example of ambiguity the study by Dahmer et al. (2018) assessing the role of the naturally occurring IL-1 (interleukin-1) receptor antagonist in the augmentation of PARDS is listed here which underlines the high complexity of natural inflammation and anti-inflammation for the disease process. As to surfactant composition, a decrease in saturated phosphatidylcholine (PC) and an increase in unsaturated PC combined with almost stable concentrations of the four surfactant proteins (SP), however an increase in SP-B as a parameter of capillary leakage, was found in children with a maximum OI of 12 (Todd et al., 2010).

In an attempt to better characterize and tackle major pro-inflammatory pathways in NARDS the neonatal piglet is the animal model of choice for reasons of availability, size, similarities of porcine and human lung, robustness, and costs. In addition, the pig's hypervariable region (HVR) of the toll-like receptor 4 shows high identity (and many nucleotide polymorphisms) with the human TLR4 HVR (Palermo et al., 2009), they are equipped with pulmonary intravascular macrophages, and show LPS sensitivity and NO production comparable to humans (Matute-Bello et al., 2008). To prove the advantages of this translational neonatal piglet model of NARDS, the physiologic data (with emphasis on lung function) from three experiments of our group are summarized here. In addition, the systematic review addresses different models of acute lung injury with respiratory failure in neonatal piglets, describes major pro-inflammatory pathways by the analysis of serum, BALF, and lung tissue, and highlights effective experimental interventions by anti-inflammatory substances.

\section{METHODS}

\section{Piglet Studies and Systematic Review: Data Sources and Searching}

A compilation of data from three NARDS studies (von Bismarck et al., 2008; Preuß et al., 2012b; Spengler et al., 2018) was used to describe basic physiologic parameters and major inflammatory pathways of the neonatal porcine lung. The studies were approved by the local Ethics Committee for Animal Research at the Ministry of Energy, Agriculture, the Environment, Nature and Digitalization of the federal state of Schleswig-Holstein in accord with the current European directive on the protection of animals used for scientific purposes. Corresponding physiologic parameters from human neonates are provided as a comparison if available and deemed necessary.

In addition a systematic review on major inflammatory pathways following single-hit or multiple-hit acute lung injury in newborn piglets was conducted using PubMed and Google Scholar databases in search of the terms "newborn piglet" combined with "(acute) lung injury," "mechanical ventilation," "respiratory failure," "lung inflammation," "meconium aspiration," "airway lavage," and "lipopolysaccharide/endotoxin." Reference lists and relevant reviews were also checked manually to recruit potentially eligible studies. Pulmonary physiology data and all data assessing inflammatory reactions secondary to acute lung injury protocols or specific interventions were extracted and reported.

\section{Neonatal Piglets, Mechanical Ventilation, Lung Injury Protocols, Interventions, and Statistics}

The study population was newborn piglets between day 2 and 6 of life and of either sex that were taken from their mother sows without any period of fasting. Genetic variability was assured by the use of mixed country breed (descendants of Danish Landrace) piglets. Their average weight of $2.5 \mathrm{~kg}$ allowed to apply the standard equipment of an average neonatal intensive care unit for instrumentation, maintenance and interventions. The number of piglets included into the data analyses were 22 in study 1 (von Bismarck et al., 2008), 29 in study 2 (Preuß et al., 2012b), and 59 in study 3 (Spengler et al., 2018).

Adequate analgesia/sedation was provided by continuous infusions of ketamine $(5 \mathrm{mg} / \mathrm{kg} / \mathrm{h})$, midazolam $(0.5 \mathrm{mg} / \mathrm{kg} / \mathrm{h})$, and vecuronium bromide $(0.8 \mathrm{mg} / \mathrm{kg} / \mathrm{h})$ throughout the whole study period of $24 \mathrm{~h}$ (study 1 ) or $72 \mathrm{~h}$ (studies 2 and 3 ). Nutritional support was provided via a nasogastric tube with $6^{*} 25 \mathrm{ml} / \mathrm{kg} / \mathrm{d}$ specialized milk designed for piglets (Babygold, Hamburger Leistungsfutter). Body temperature of $38-39^{\circ} \mathrm{C}$ was maintained by positioning the piglets on a homeothermic blanket (Harvard Apparatus) and applying a rectal probe with the servocontrol mode.

All piglets received mechanical ventilation via an orally inserted $3.5 \mathrm{~mm}$ endotracheal double lumen tube. Continuousflow pressure-limited neonatal ventilators (Babylog 1, Dräger) were used with the following initial settings: PEEP $=6$ mbar, inspiratory time $=0.5 \mathrm{~s}, f=25 / \mathrm{min}, \mathrm{FiO}_{2}=0.5$, PIP adjusted to maintain a tidal volume $=7 \mathrm{ml} / \mathrm{kg}$ as measured by NVM-1 (Bear) throughout the study. To avoid hypo/hyperventilation and hypoxemia/hyperoxemia, $\mathrm{f}$ and $\mathrm{FiO}_{2}$ were regularly adjusted according to the results of arterial blood gas analyses. An oxygenation index (OI: MAP * $\% \mathrm{O}_{2} / \mathrm{PaO}_{2}$, with $\mathrm{MAP}=$ mean airway pressure) and a ventilation efficiency index (VEI: $3800 /$ PIP-PEEP $* f * \mathrm{PaCO}_{2}$ ) were calculated from the parameters of the ventilator and the results of the arterial blood gas analysis. Functional residual capacity (FRC, $\mathrm{ml} / \mathrm{kg}$ ), the alveolar portion of the tidal volume $\left(\mathrm{V}_{\mathrm{A}}, \mathrm{ml}\right)$, tidal volume $\left(\mathrm{V}_{\mathrm{T}}, \mathrm{ml}\right)$ (specific) compliance of the respiratory system $\left(\mathrm{sC}_{\mathrm{rs}}\right.$, $\mathrm{ml} / \mathrm{mbar} / \mathrm{kg})$, and resistance of the respiratory system $\left(\mathrm{R}_{\mathrm{rs}}\right.$, $\mathrm{mbar} / \mathrm{l}^{*} \mathrm{~s}$ ) were assessed by the nitrogen washout method for lung volumes, and the single breath least-squares method for lung mechanics.

Hemodynamic monitoring was provided by PiCCO plus monitors (Pulsion) yielding a continuous monitoring of heart rate (HR), blood pressure (BP), heart index (HI), peripheral vascular resistance (SVRI), stroke volume variation (SVV), and extra-vascular lung water index (EVLWI). 
Urine output was monitored continuously by the insertion of a suprapubic bladder catheter.

Two different lung injury protocols were used: in study 1, lung injury was provided by repeated airway lavage with warmed normal saline $(30 \mathrm{ml} / \mathrm{kg})$ until the $\mathrm{PaO}_{2}$ was $\sim 100 \mathrm{mmHg}$ and stayed at that level for at least $20 \mathrm{~min}$ (single-hit lung injury). In studies 2 and 3, three consecutive lung injury protocols were carried out of which the first one was repeated airway lavage as described above, followed by a $2 \mathrm{~h}$ period of injurious ventilation (by the use of a $V_{\mathrm{T}}=15 \mathrm{ml} / \mathrm{kg}$ and PEEP $=0 \mathrm{mbar}$ ) $24 \mathrm{~h}$ later, and by the endotracheal instillation of $2.5 \mathrm{mg}$ LPS (E. coli serotype O127:B8; Sigma-Aldrich) $48 \mathrm{~h}$ later (triple-hit lung injury).

Next to the control groups (C) subject to an air bolus only, the piglets received surfactant (poractant alfa, Curosurf, Chiesi) at a dosage of $1^{*} 100 \mathrm{mg} / \mathrm{kg}$ (study 1) or $3^{*} 50$ (200) $\mathrm{mg} / \mathrm{kg}$ every $24 \mathrm{~h}$ apart (studies 2 and 3 ) as an intervention. In several intervention groups the surfactant was "fortified" by additional immune-suppressive agents: imipramine $5 \mathrm{mg}$ admixed to surfactant (study 1), D-myo-inositol-1,2,6trisphosphate $2 / 2.5 \mathrm{mg}$ (Cayman) (studies 2 and 3), myoinositol $40 \mathrm{mg}$ (Sigma-Aldrich) (study 2), phosphatidylinositol3,5-bisphosphate $2.5 \mathrm{mg}$ (Cayman) (study 3), palmitoyl-oleoylphosphatidylglycerol $7.5 \mathrm{mg}$ (Avanti) (study 3), and dioleoylphosphatidylglycerol $7.5 \mathrm{mg}$ (Avanti) (study 3). In this analysis the data of all intervention groups from one study are combined as the treatment group $(\mathrm{T})$; the combination of $\mathrm{C}$ and $\mathrm{T}$ is reported as the total group in the tables to point out deviations from means and to prove the stability of the model. Study 3 also analyzed a group of piglets not being subject to sedation and mechanical ventilation that is reported as healthy controls (HC).

Next to the assessment of physiologic parameters, a variety of specific pulmonary parameters of the immune response to single-hit/triple-hit lung injury were performed by the use of lung sections (e.g., histology), lung homogenates (e.g., acid sphingomyelinase activity), and broncho-alveolar lavage fluid (BALF, e.g., cell differentials). For further details we refer to the detailed description of all applied methods in the methods sections of the referenced publications (von Bismarck et al., 2008; Preuß et al., 2012b; Spengler et al., 2018).

For repeated-measures data the two-way mixed ANOVA was used to determine whether there were differences of an independent variable [between subject factor: control (C), treatment $(\mathrm{T})$, overall $(\mathrm{O})$ ] over time (within subject factor: baseline, 24, 48, $72 \mathrm{~h}$ ). A normal distribution of the independent variable was assessed by Shapiro-Wilk's test $(p>0.05)$. Equality of error variances using Levene's test and equality of covariance matrices by Box's $M$ test was carried out for every parameter; in case of heteroscedasticity data were transformed by the BoxCox transformation before analysis. Mauchly's test of sphericity was performed on every parameter to check for significant two-way interaction $(p<0.05)$. The within subject factor and the interaction (within subject factor $*$ between subject factor) were calculated by Greenhouse-Geisser correction in case the estimated epsilon was $<0.75$. The main effect of the between subject factor (group) on the independent variable was considered statistically significant in case of $p<0.05$. Single data sets were checked for deviations from normality using the Shapiro-Wilk's test $(p>0.05)$. Normally distributed data were analyzed by unpaired $t$-tests, and non-parametric data by Mann-Whitney $U$ tests. All data are presented as means \pm SD. The analyses were performed by SPSS version 24 (IBM, Ehningen, Germany).

\section{Systematic Review: Study Selection, Data Extraction, and Assessment of Risk of Bias}

Two authors (DS and NR) independently screened the titles provided by the combination of different search terms indicated above. The inclusion criteria were: studies published in English within the last 30 years following peer-review, studies reporting information on NARDS in neonatal piglets following distinct experimental lung injury protocols, studies reporting on major inflammatory pathways and their mediators. Publications were excluded if they did not report on a setting of invasive mechanical ventilation with at least one acute lung injury protocol, and if no adequate control group was presented. The quality of studies was independently evaluated by the two authors using the Quality Assessment Tool for Case-Control Studies by the National Heart, Lung, and Blood Institute (NHLBI) ${ }^{1}$.

\section{RESULTS AND DISCUSSION}

\section{Circulation}

The cardiovascular stability was challenged in the context of direct and indirect manipulations of heart, systemic, and pulmonary circulation. In addition, the possible pharmacologic effects of sedatives/analgetics must be taken into account. For a sufficient stability of the circulation some drug classes, such as barbiturates and opiods seem to be less suited because of their negative inotropic action on the myocardium. In models covering more than $12 \mathrm{~h}$ of mechanical ventilation a cumulative effect and a progressive decline in HI and SVRI can be observed. As sufficient analgesia is paramount in any model opioids should be used for instrumentation and for all kinds of painful procedures, however, for long time sedation and analgesia ketamine (in combination with low dose benzodiazepine) seems to be more apt because of its positive inotropic effect even in the presence of muscular blockade.

The combined effects of the triple-hit lung injury protocol (repeated airway lavage, injurious ventilation, and endotracheal endotoxin installation) on cardiovascular parameters are shown in Table 1 covering a time window of $72 \mathrm{~h}$ (Spengler et al., 2018). The cardiovascular function is characterized by high stability in heart rate (HR), systolic and diastolic blood pressure (S/DBP), heart index (HI), systemic vascular resistances index (SVRI), intrathoracic blood volume index (ITBI), stroke volume index (SVI), and stroke volume variation (SVV) over $72 \mathrm{~h}$ of invasive monitoring despite statistically significant changes in DBP, SVRI, SVI, and SVV (time) and HR (time* group) (Table 1). However, no single parameter shows a continuously increasing or decreasing trend. We observed progressing blood pressure

\footnotetext{
${ }^{1}$ National Heart, Lung, and Blood Institute. Study Quality Assessment Tools, Quality of Case-Control Studies. Available online at: https://www.nhlbi.nih.gov/ health-topics/study-quality-assessment-tools.
} 
TABLE 1 | Circulation.

\begin{tabular}{|c|c|c|c|c|c|c|c|c|c|}
\hline & & Baseline & $24 \mathrm{~h}$ & $48 \mathrm{~h}$ & $72 \mathrm{~h}$ & Sphericity & Time & Time* group & Group \\
\hline \multirow[t]{2}{*}{$\mathrm{HR}$ (bpm) } & Total & $181 \pm 25$ & $175 \pm 27$ & $158 \pm 24$ & $156 \pm 26$ & 0.04 & 0.35 & 0.01 & 0.72 \\
\hline & Control & $177 \pm 29$ & $182 \pm 31$ & $157 \pm 20$ & $146 \pm 31$ & & & & \\
\hline \multirow[t]{2}{*}{$\mathrm{SBP}(\mathrm{mmHg})$} & Total & $99 \pm 15$ & $89 \pm 12$ & $99 \pm 15$ & $97 \pm 12$ & 0.47 & 0.79 & 0.45 & 0.39 \\
\hline & Control & $100 \pm 15$ & $86 \pm 13$ & $98 \pm 16$ & $92 \pm 11$ & & & & \\
\hline \multirow{2}{*}{$\mathrm{DBP}(\mathrm{mmHg})$} & Control & $59 \pm 6$ & $45 \pm 7$ & $51 \pm 7$ & $45 \pm 6$ & & & & \\
\hline & Treat & $55 \pm 9$ & $44 \pm 7$ & $52 \pm 8$ & $50 \pm 10$ & & & & \\
\hline \multirow[t]{3}{*}{$\mathrm{HI}\left(1 / \mathrm{min} / \mathrm{m}^{2}\right)$} & Total & $3.9 \pm 0.7$ & $3.8 \pm 0.9$ & $3.8 \pm 0.8$ & $4.0 \pm 0.9$ & 0.52 & 0.21 & 0.37 & 0.58 \\
\hline & Control & $4.1 \pm 0.9$ & $3.6 \pm 1.0$ & $3.9 \pm 0.9$ & $4.3 \pm 1.0$ & & & & \\
\hline & Treat & $3.8 \pm 0.7$ & $3.9 \pm 0.8$ & $3.8 \pm 0.8$ & $3.9 \pm 0.9$ & & & & \\
\hline \multirow[t]{3}{*}{ ITBI $\left(\mathrm{ml} / \mathrm{m}^{2}\right)$} & Total & $276 \pm 56$ & $308 \pm 117$ & $295 \pm 68$ & $298 \pm 81$ & 0.00 & 0.49 & 0.88 & 0.46 \\
\hline & Control & $300 \pm 18$ & $323 \pm 75$ & $318 \pm 58$ & $331 \pm 77$ & & & & \\
\hline & Treat & $269 \pm 62$ & $305 \pm 128$ & $288 \pm 71$ & $289 \pm 83$ & & & & \\
\hline \multirow[t]{3}{*}{$\mathrm{SVI}\left(\mathrm{ml} / \mathrm{m}^{2}\right)$} & Total & $23.5 \pm 6.6$ & $22.7 \pm 6.2$ & $25.0 \pm 6.1$ & $26.1 \pm 7.1$ & 0.16 & 0.00 & 0.09 & 0.50 \\
\hline & Control & $27.6 \pm 11.1$ & $21.5 \pm 6.1$ & $23.7 \pm 6.8$ & $28.0 \pm 5.9$ & & & & \\
\hline & Treat & $22.7 \pm 5.6$ & $22.7 \pm 5.0$ & $24.4 \pm 5.2$ & $25.9 \pm 7.1$ & & & & \\
\hline \multirow[t]{3}{*}{ SW (\%) } & Total & $12.4 \pm 3.8$ & $9.6 \pm 3.1$ & $10.1 \pm 3.9$ & $8.8 \pm 3.5$ & 0.34 & 0.00 & 0.58 & 0.67 \\
\hline & Control & $12.5 \pm 4.2$ & $10.6 \pm 1.8$ & $9.6 \pm 4.4$ & $7.1 \pm 3.2$ & & & & \\
\hline & Treat & $12.4 \pm 3.9$ & $9.4 \pm 3.3$ & $10.2 \pm 3.8$ & $9.1 \pm 3.5$ & & & & \\
\hline
\end{tabular}

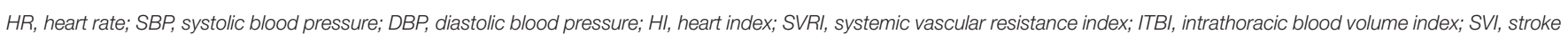
volume index; SW, stroke volume variation.

Data are mean $\pm S D$. Number of piglets included: total $=51$, control $=8$, treat(ment) $=43$. Comparisons by two-way mixed ANOVA for repeated measures data.

instability combined with increasing SVRI and decreasing HI in only 5/67 (7.5\%) piglets, a reason for drop-out in this model.

Data of circulatory parameters in the non-anesthetized piglet have been published by Eisenhauer et al. (1994) studying chronically instrumented neonatal piglets being individually raised and fed. The heart rate of $187 \pm 28 \mathrm{bpm}$ and the mean blood pressure of $66 \pm 4 \mathrm{~mm} \mathrm{Hg}$ are very close to the values obtained in our piglets at baseline being subject to anesthesia and mechanical ventilation, suggesting only minor influences of ketamine/midazolam/vecuronium bromide given as continuous drips on hemodynamic function. This is supported by the data from 5 to 7 days old piglets being subject to anesthesia with halothane and invasive blood pressure monitoring yielding values for SBP of $89 \mathrm{mmHg}$ (CI 84-99) and DBP of $54 \mathrm{mmHg}$ (51-60) (Voss et al., 2004). Using the thermodilution technique HI was $4.04-4.38 \pm 1.23-1.42 \mathrm{l} / \mathrm{min} / \mathrm{m}^{2}$, and the SVI $20.4 / 20.4$ $\pm 5.7-9.5 \mathrm{ml} / \mathrm{m}^{2}$ in 13 days old piglets (Gibson et al., 1994), and ITBI $230 \pm 76 \mathrm{ml} / \mathrm{m}^{2}$ in $1-3$ days old piglets (Silvera et al., 2011).

The data of 90 healthy human neonates on day 3 of life assessed by ultrasonic cardiac output monitoring yielded the following results: HR $119 \pm 12 \mathrm{bpm}, \mathrm{SBP} 73 \pm 4 \mathrm{mmHg}$, DBP $39 \pm 5 \mathrm{mmHg}$, HI $3.0 \pm 0.6 \mathrm{l} / \mathrm{min} / \mathrm{m}^{2}$, SVRI $1,403 \pm$ 291 dyne* $\mathrm{sec}^{*} \mathrm{~cm}^{-5 *} \mathrm{~m}^{2}$, and SVI $25.3 \pm 5.1 \mathrm{ml} / \mathrm{m}^{2}$ (He et al., 2011). By the thermodilution technique in human newborns after arterial switch procedure due to transposition of the great arteries, CI was $4.0 \pm 0.6 \mathrm{l} / \mathrm{min} / \mathrm{m}^{2}$, SVRI $1,150 \pm 295$ dyne* $\sec ^{*} \mathrm{~cm}^{-5 *} \mathrm{~m}^{2}$, ITBI $489 \pm 125 \mathrm{ml} / \mathrm{m}^{2}$, and SVI 33.1 $\pm 4.3 \mathrm{ml} / \mathrm{m}^{2}$ (Székely et al., 2011). While these latter data are probably not representative for healthy human newborns, there are obvious differences in circulation between porcine and human newborns: the porcine circulation generates a significant higher S/DBP level due to a higher HR and HI whereas SVRI is comparable to human values. In view of similar heart/body weight relationships [porcine: $0.89 \pm 0.06 \%$ (Miles et al., 2012), $0.69 \pm 0.02 \%$ (Amdi et al., 2013), $0.70 \pm 0.06$ (Farmer et al., 2016); human: 0.62-0.75 $\pm 0.35-0.50$ (Corrèa et al., 2014)], an important prerequisite for circulatory stability, the piglet model excels over rodent animal models.

\section{Electrolytes and Renal Function}

We observed significant (however clinically irrelevant) timedependent changes in electrolytes, creatinine, and GOT (Table 2). Plasma Na (143 $\pm 5 \mathrm{mmol} / \mathrm{l}, 138 \pm 3)$ and $\mathrm{K}(4.4 \pm 0.8$ $\mathrm{mmol} / \mathrm{l}, 4.2 \pm 0.4$ ) concentrations in 2-5 days old piglets were comparable to our results (Parker and Aherne, 1980; Eisenhauer et al., 1994). The rather low $\mathrm{K}$ concentrations in our study (3.2 $\pm 0.7 \mathrm{mmol} / \mathrm{l}$ ) suggest that the phase of increased newborn hemolysis yielding higher $\mathrm{K}$ serum concentrations is almost 
TABLE 2 | Electrolytes, renal function, and GOT.

\begin{tabular}{|c|c|c|c|c|c|c|c|c|c|}
\hline & & Baseline & $24 \mathrm{~h}$ & $48 \mathrm{~h}$ & $72 \mathrm{~h}$ & Sphericity & Time & Time*group & Group \\
\hline \multirow[t]{3}{*}{ Sodium (mmol/l) } & Total & $141 \pm 2$ & $141 \pm 2$ & $143 \pm 4$ & $144 \pm 4$ & 0.00 & 0.00 & 0.86 & 0.94 \\
\hline & Control & $142 \pm 2$ & $141 \pm 2$ & $143 \pm 2$ & $144 \pm 2$ & & & & \\
\hline & Treat & $141 \pm 2$ & $141 \pm 3$ & $143 \pm 4$ & $145 \pm 4$ & & & & \\
\hline \multirow[t]{3}{*}{ Potassium (mmol/l) } & Total & $3.2 \pm 0.7$ & $4.5 \pm 0.7$ & $3.9 \pm 0.4$ & $3.8 \pm 0.3$ & 0.00 & 0.00 & 0.30 & 0.22 \\
\hline & Control & $2.8 \pm 0.8$ & $4.7 \pm 0.6$ & $3.7 \pm 0.1$ & $3.7 \pm 0.2$ & & & & \\
\hline & Treat & $3.3 \pm 0.7$ & $4.5 \pm 0.7$ & $3.9 \pm 0.5$ & $3.8 \pm 0.3$ & & & & \\
\hline \multirow[t]{3}{*}{ Calcium (mmol/l) } & Total & $2.6 \pm 0.1$ & $2.4 \pm 0.1$ & $2.5 \pm 0.1$ & $2.5 \pm 0.1$ & 0.10 & 0.00 & 0.29 & 0.98 \\
\hline & Control & $2.6 \pm 0.1$ & $2.5 \pm 0.1$ & $2.5 \pm 0.1$ & $2.5 \pm 0.1$ & & & & \\
\hline & Treat & $2.6 \pm 0.1$ & $2.4 \pm 0.1$ & $2.5 \pm 0.1$ & $2.5 \pm 0.1$ & & & & \\
\hline \multirow[t]{3}{*}{ Chloride $(\mathrm{mmol} / \mathrm{l})$} & Total & $103 \pm 3$ & $106 \pm 3$ & $106 \pm 4$ & $107 \pm 5$ & 0.00 & 0.00 & 0.62 & 0.76 \\
\hline & Control & $104 \pm 3$ & $107 \pm 3$ & $106 \pm 3$ & $108 \pm 5$ & & & & \\
\hline & Treat & $103 \pm 3$ & $106 \pm 3$ & $107 \pm 4$ & $107 \pm 5$ & & & & \\
\hline \multirow[t]{3}{*}{ Creatinine (mg/dl) } & Total & $0.53 \pm 0.09$ & $0.60 \pm 0.21$ & $0.51 \pm 0.12$ & $0.42 \pm 0.08$ & 0.00 & 0.00 & 0.69 & 0.26 \\
\hline & Control & $0.54 \pm 0.08$ & $0.66 \pm 0.16$ & $0.53 \pm 0.12$ & $0.45 \pm 0.07$ & & & & \\
\hline & Treat & $0.53 \pm 0.09$ & $0.59 \pm 0.22$ & $0.50 \pm 0.13$ & $0.41 \pm 0.08$ & & & & \\
\hline Urine output (ml/kg/h) & & & & & $2.2 \pm 0.8$ & & & & \\
\hline \multirow[t]{3}{*}{ GOT (AST) (IU/I) } & Total & $31 \pm 6$ & $51 \pm 27$ & $53 \pm 37$ & $39 \pm 32$ & 0.00 & 0.00 & 0.85 & 0.74 \\
\hline & Control & $31 \pm 6$ & $46 \pm 26$ & $54 \pm 45$ & $35 \pm 28$ & & & & \\
\hline & Treat & $31 \pm 7$ & $52 \pm 27$ & $52 \pm 35$ & $40 \pm 33$ & & & & \\
\hline
\end{tabular}

GOT (AST), glutamic oxaloacetic aminotransferase (aspartate aminotransferase).

Data are mean $\pm S D$. Number of piglets included: total $=51$, control $=8$, treat(ment) $=43$. Comparisons by two-way mixed ANOVA for repeated measures data

completed at the time of baseline measurements. GOT and creatinine in 18 three days old piglets were $36 \pm 6 \mathrm{U} / \mathrm{l}$ and 0.47 $\pm 0.03 \mathrm{mg} / \mathrm{dl}$ at baseline in a cecal ligation model (Goto et al., 2012). Data on urine production dependent on body weight have not yet been published to the best of our knowledge. Urine production depends on fluid intake and post-natal age and averages in the human infant between 2 and $5 \mathrm{ml} / \mathrm{kg} / \mathrm{h}$. The fluid intake in our protocol followed accepted guidelines (Petersen et al., 2003) and consisted of $\sim 200 \mathrm{ml} / \mathrm{kg} / \mathrm{d}$ consisting of $3 / 4$ enteral nutrition fluids and $1 / 4$ intravenous fluids.

\section{Blood Cell Differentials}

We observed time-dependent changes in all blood cell lines (monocytes excepted) and a significant interaction for thrombocytes (time* group). Most of the cell lines did not show a clear trend, the administration of LPS at $48 \mathrm{~h}$ included (Table 3). The hematocrit of 2-5 days old piglets was $27 \pm 2 \%$ (equivalent to a hemoglobin concentration of $9.0 \pm 0.6 \mathrm{~g} / \mathrm{dl}$ ) (Eisenhauer et al., 1994) and $8.5 \pm 3.2 \mathrm{~g} / \mathrm{dl}$ in piglets on day 1 and 2 (Park and Chang, 2000).

Clearly, the hematocrit of term newborns at $48 \mathrm{~h}$ of age is higher $[17.7 \mathrm{~g} / \mathrm{dl} \pm 1.8$ to $19.5 \pm 2.1$ depending on the mode of cord clamping (Mercer et al., 2017)] thus doubling the oxygen transport capacity and making the human newborn less vulnerable to an impaired gas exchange in the transitional period.

\section{Lung Function}

The determination of EVLWI has been performed by the thermodilution method in newborn piglets yielding a value of $20 \pm 1 \mathrm{ml} / \mathrm{kg}$ (Silvera et al., 2011) and in human neonates following arterial switch operation due to transposition of the great arteries yielding $20 \pm 7 \mathrm{ml} / \mathrm{kg}$ after extubation (Székely et al., 2011), however data in well babies do not exist because of the invasiveness of the technique. In (adult) humans a value of $3-7 \mathrm{ml} / \mathrm{kg}$ is considered normal, however neonates tend to have higher values because of incomplete resorption of lung fluids in the post-natal transitional process and of shunting via a patent ductus arteriosus and foramen ovale. Our baseline data of "total" $(13.2 \pm 5.5 \mathrm{ml} / \mathrm{kg}$, Table 4) are close to the values of newborn neonatal lambs assessed by multiple indicator dilution methods showing an EVLWI of $10.7 \pm 1.4 \mathrm{ml} / \mathrm{kg}$ (Sundell et al., 1987).

Baseline $\mathrm{sC}_{\mathrm{rs}}$ in mechanically ventilated neonatal piglets has been determined by many researchers with values of $1.34 \pm 0.11$ $\mathrm{ml} / \mathrm{mbar} / \mathrm{kg}$ (Sood et al., 1996a), $0.79 \pm 0.15$ (Khan et al., 1999), $1.5 \pm 0.3$ (Tølløfsrud et al., 2002), $0.95 \pm 0.05$ (Dargaville et al., 2003), $1.03 \pm 0.33$ (Meister et al., 2004), $1.38 \pm 0.15$ (Chada et al., 2008), and $1.07 \pm 0.17$ (Yang et al., 2010). These data are close to our "total" value of $1.14 \pm 0.51 \mathrm{ml} / \mathrm{mbar} / \mathrm{kg}$, in contrast to $\mathrm{R}_{\mathrm{rs}}$ values ("total": $59 \pm 11 \mathrm{mbar} / \mathrm{l}^{*} \mathrm{~s}$ ) showing greater variations which occur due to differences in body weight, endotracheal tube size and leakage, amount of continuous flow in the ventilator tubings, and medication: $32 \pm 3 \mathrm{mbar} / \mathrm{l}^{*} \mathrm{~s}$ (Sood et al., 1996a), $88 \pm 9$ (Tølløfsrud et al., 2002), $74 \pm 4$ (Dargaville et al., 2003), and $64 \pm 8$ (Meister et al., 2004). FRC is considered the main determinant of oxygenation and is deemed to be significantly reduced by any lung injury protocol ("control": from $28.7 \pm 6.3$ $\mathrm{ml} / \mathrm{kg}$ to $18.4 \pm 5.4$ after $24 \mathrm{~h}$ of mechanical ventilation following repeated airway lavage); FRC was $21.8 \pm 2.4 \mathrm{ml} / \mathrm{kg}$ in three days old piglets (Standaert et al., 1991) and $21 \pm 2$ in 5-7 days old piglets (Meister et al., 2004). To the best of our knowledge, data 
TABLE 3 | Blood cell differentials.

\begin{tabular}{|c|c|c|c|c|c|c|c|c|c|}
\hline & & Baseline & $24 \mathrm{~h}$ & $48 \mathrm{~h}$ & $72 \mathrm{~h}$ & Sphericity & Time & Time*group & Group \\
\hline \multirow[t]{3}{*}{ Hemoglobin (g/dl) } & Total & $8.0 \pm 1.1$ & $7.8 \pm 1.1$ & $7.5 \pm 0.9$ & $7.5 \pm 0.8$ & 0.00 & 0.00 & 0.31 & 0.53 \\
\hline & Control & $8.2 \pm 0.8$ & $8.2 \pm 0.9$ & $7.5 \pm 0.6$ & $7.6 \pm 0.8$ & & & & \\
\hline & Treat & $7.9 \pm 1.2$ & $7.7 \pm 1.1$ & $7.5 \pm 0.9$ & $7.5 \pm 0.8$ & & & & \\
\hline \multirow[t]{2}{*}{ Leukocytes (cells/nl) } & Total & $15.0 \pm 6.6$ & $21.3 \pm 8.7$ & $15.5 \pm 6.6$ & $12.4 \pm 5.7$ & 0.20 & 0.00 & 0.31 & 0.06 \\
\hline & Control & $16.1 \pm 9.2$ & $26.3 \pm 13.2$ & $18.4 \pm 10.4$ & $15.2 \pm 7.0$ & & & & \\
\hline \multirow{2}{*}{ Thrombocytes (cells/nl) } & Control & $494 \pm 141$ & $464 \pm 109$ & $372 \pm 160$ & $340 \pm 161$ & & & & \\
\hline & Treat & $431 \pm 82$ & $457 \pm 89$ & $424 \pm 124$ & $410 \pm 138$ & & & & \\
\hline \multirow[t]{3}{*}{ Bands (\%) } & Total & $12 \pm 8$ & $12 \pm 9$ & $7 \pm 6$ & $13 \pm 8$ & 0.15 & 0.00 & 0.31 & 0.67 \\
\hline & Control & $12 \pm 7$ & $16 \pm 15$ & $5 \pm 7$ & $15 \pm 10$ & & & & \\
\hline & Treat & $12 \pm 8$ & $11 \pm 6$ & $7 \pm 5$ & $13 \pm 8$ & & & & \\
\hline \multirow[t]{3}{*}{ Lymphocytes (\%) } & Total & $16 \pm 7$ & $13 \pm 6$ & $20 \pm 11$ & $25 \pm 11$ & 0.00 & 0.00 & 0.62 & 0.55 \\
\hline & Control & $17 \pm 9$ & $12 \pm 5$ & $20 \pm 12$ & $21 \pm 10$ & & & & \\
\hline & Treat & $16 \pm 6$ & $14 \pm 6$ & $21 \pm 10$ & $26 \pm 11$ & & & & \\
\hline \multirow[t]{3}{*}{ Monocytes (\%) } & Total & $2 \pm 1$ & $1 \pm 1$ & $1 \pm 2$ & $1 \pm 2$ & 0.13 & 0.67 & 0.34 & 0.62 \\
\hline & Control & $1 \pm 1$ & $1 \pm 1$ & $1 \pm 1$ & $2 \pm 2$ & & & & \\
\hline & Treat & $2 \pm 1$ & $1 \pm 1$ & $1 \pm 2$ & $1 \pm 2$ & & & & \\
\hline
\end{tabular}

PMNL, polymorphonuclear leukocytes.

Data are mean $\pm S D$. Number of piglets included: total $=51$, control $=8$, treat(ment) $=43$. Comparisons by two-way mixed ANOVA for repeated measures data

on $\mathrm{V}_{\mathrm{A}}$ have not been published by other investigators but were measured with $4.8 \pm 0.3 \mathrm{ml} / \mathrm{kg}$ in a previous study of our group (Krause et al., 2001).

Impairment of oxygenation is a prerequisite of P/NARDS and is usually defined by the OI which is an equation composed of the degree of respiratory support (mean airway pressure, MAP), the oxygen concentration in respiratory gas mixtures, and the partial pressure of $\mathrm{O}_{2}$ in blood as a measure of gas exchange $\left(\mathrm{MAP} * \% \mathrm{O}_{2} / \mathrm{PaO}_{2}\right)$. By the Montreux definition of NARDS (De Luca et al., 2017), the control group experienced severe NARDS expressed by an OI of $16.1 \pm 6.1$ at $72 \mathrm{~h}$ of mechanical ventilation (Table 4). Baseline values in our study ("total": $2.3 \pm 0.7$ ) are close to those from other investigators: $1.5 \pm 0.5 \mathrm{ml} / \mathrm{mbar} / \mathrm{kg}$ (Khan et al., 1999), $1.4 \pm 0.3$ (Tølløfsrud et al., 2002), and $1.3 \pm 0.3$ (Renesme et al., 2013). The VEI in "total" $(0.38 \pm 0.19)$ is close to the value of 6 days old piglets at baseline $(0.30 \pm 0.02)$ in the lavage study by Sood et al. (1996a) and to the value of 5 days old piglets $(0.33 \pm 0.08)$ in the meconium aspiration study by Khan et al. (1999).

\section{Bacteria in Airways}

A plentitude of different bacteria in the airways was cultured with the initial lavage mainly belonging to the three groups of (lacto)bacillales, enterobacteriaceae, and soil-based bacteria (Table 5). Given the relative dominance of soil-based bacteria in the airways of our piglets (Bacillus cereus, Rothia, aerobic spore builder, Corynebacterium sp.) inhalation of these microorganisms due to the use of the piglets' nose for foraging and consecutive colonization of upper and lower airways must be considered. The high frequency in bacillus cereus colonization (in 8/52 cultures from the final lavages) demonstrates the natural resistance to beta-lactams, e.g., ampicillin \pm sulbactam as given in our study (Glasset et al., 2018). The increasing prevalence of colonization by multidrug resistant Gram-negative bacteria, such as E. coli and Klebsiella sp. in neonatal intensive care units (NICU) are correlated with length of NICU stay, and-indeed-exposure to ampicillin/sulbactam (Giuffrè et al., 2016).

\section{Lung and Body Weights}

We determined a lung/body weight relation of $1.6 \pm 0.2 \%$ (Table 6) which is in line with the findings in 6 three days old piglets [1.5 \pm 0.2 (Standaert et al., 1991)], of $1.0 \pm 0.1$ in 8 fourteen days old piglets (Dargaville et al., 2003), $3.0 \pm 0.3$ in 13 three days old piglets (van Kaam et al., 2004b), and $1.7 \pm 0.1$ in 27 one day old piglets (Miles et al., 2012). The applicability of the neonatal piglet lung model for studying severe lung diseases is also expressed by the similarities to term human lung/body relations of $1.7 \pm 0.4 \%$ (De Paepe et al., 2005) and $1.9 \pm 0.3$ (De Paepe et al., 2014).

\section{Cells in BALF and Apoptosis}

There is currently no reliable indicator to assess the amount of epithelial lining fluid recovered by broncho-alveolar lavage (de Blic et al., 2000). Most commonly urea and albumen have been used as reference substances, however, lower serum 
TABLE 4 | Lung function.

\begin{tabular}{|c|c|c|c|c|c|c|c|c|c|}
\hline & & Baseline & $24 \mathrm{~h}$ & $48 h$ & $72 \mathrm{~h}$ & Sphericity & Time & Time* group & Group \\
\hline \multirow[t]{3}{*}{ EVLWI (ml/kg) } & Total & $13.2 \pm 5.5$ & $18.1 \pm 9.4$ & $18.4 \pm 7.9$ & $23.3 \pm 8.4$ & 0.01 & 0.00 & 0.16 & 0.00 \\
\hline & Control & $15.5 \pm 5.4$ & $25.0 \pm 5.5$ & $25.0 \pm 5.3$ & $30.6 \pm 5.7$ & & & & \\
\hline & Treat & $12.7 \pm 5.5$ & $16.8 \pm 9.5$ & $17.2 \pm 7.7$ & $22.0 \pm 8.1$ & & & & \\
\hline \multirow[t]{2}{*}{$\mathrm{C}_{\mathrm{rs}}(\mathrm{ml} / \mathrm{mbar} / \mathrm{kg})$} & Total & $1.14 \pm 0.51$ & $0.72 \pm 0.30$ & $0.60 \pm 0.23$ & $0.57 \pm 0.19$ & 0.00 & 0.00 & 0.50 & 0.22 \\
\hline & Control & $1.14 \pm 0.40$ & $0.69 \pm 0.25$ & $0.51 \pm 0.09$ & $0.42 \pm 0.12$ & & & & \\
\hline & Control & $57 \pm 13$ & $80 \pm 25$ & $125 \pm 55$ & $141 \pm 57$ & & & & \\
\hline & Treat & $60 \pm 10$ & $82 \pm 31$ & $92 \pm 33$ & $87 \pm 20$ & & & & \\
\hline \multirow[t]{3}{*}{$\mathrm{FRC}(\mathrm{ml} / \mathrm{kg})$} & Total & $28.7 \pm 6.0$ & $19.5 \pm 6.2$ & - & - & - & 0.00 & 0.04 & 0.18 \\
\hline & Control & $28.7 \pm 6.3$ & $18.4 \pm 5.4$ & & & & & & \\
\hline & Treat & $28.7 \pm 6.3$ & $23.8 \pm 7.5$ & & & & & & \\
\hline \multirow[t]{3}{*}{$\mathrm{OI}\left(\mathrm{MAP}^{*} \% \mathrm{O}_{2} / \mathrm{PaO}_{2}\right)$} & Total & $2.3 \pm 0.7$ & $5.8 \pm 3.4$ & $7.2 \pm 3.8$ & $8.7 \pm 4.9$ & 0.03 & 0.00 & 0.00 & 0.14 \\
\hline & Control & $2.0 \pm 0.6$ & $5.0 \pm 2.7$ & $6.9 \pm 3.0$ & $16.1 \pm 6.1$ & & & & \\
\hline & Treat & $2.4 \pm 0.6$ & $6.0 \pm 3.5$ & $7.2 \pm 4.0$ & $7.5 \pm 3.7$ & & & & \\
\hline \multirow[t]{3}{*}{$\operatorname{VEI}\left(3,800 /\left(\mathrm{PIP}-\mathrm{PEEP} \mathrm{P}^{\star \star} \mathrm{PaCO}_{2}\right)\right)$} & Total & $0.38 \pm 0.19$ & $0.17 \pm 0.09$ & $0.19 \pm 0.10$ & $0.15 \pm 0.07$ & 0.00 & 0.00 & 0.00 & 0.13 \\
\hline & Control & $0.53 \pm 0.23$ & $0.18 \pm 0.09$ & $0.19 \pm 0.08$ & $0.14 \pm 0.09$ & & & & \\
\hline & Treat & $0.35 \pm 0.17$ & $0.17 \pm 0.09$ & $0.19 \pm 0.11$ & $0.15 \pm 0.06$ & & & & \\
\hline
\end{tabular}

EVLWI, extra-vascular lung water index; $s C_{r s}$, specific compliance of the respiratory system; $R_{r s}$, resistance of the respiratory system; FRC, functional residual capacity; $V_{A}$, alveolar ventilation; OI, oxygenation index; VEI, ventilation efficiency index.

Data are mean $\pm S D$. Number of piglets included: total $=51$, control $=8$, treat $=43\left(F R C / N_{A}\right.$ : total $=22$, control $=7$, treat $\left.=15\right)$. Comparisons by two-way mixed $A N O V A$ for repeated measures data.

concentrations of both substances in the smallest children bedevil the interpretation of cellular and non-cellular concentrations in BALF, as do the size of the lungs, the region of interest within the lung (in the context of bronchoscopic BALF recovery), the amount of lavage fluid used, the aspiration technique, and the processing of cellular and non-cellular components. The lavage protocol used in our studies consisted of the instillation and aspiration of $30 \mathrm{ml} / \mathrm{kg}$ of warmed normal saline by a syringe hooked up to the adaptor of the endotracheal tube.

An increased BALF total cell count $>150$ cells/ $\mu$ l is a common characteristic of many lung diseases in infants and children (Riedler et al., 1995). Thus, the total cell count of $633 \pm 336 / \mu 1$ (Table 7) in our study at baseline suggests an important impact of bacterial colonization in the majority of the piglets $(43 / 51=84 \%)$. The dominance of alveolar macrophages in newborns/young infants with $\sim 98 \%$ in cell differentials changes over time and reaches $\sim 90 \%$ at an age of 7 years (Grigg and Riedler, 2000), linked with an appropriate increase of the lymphocyte counts. Not surprisingly the PMNL count of $32 \pm 14 \%$ in our study is much higher than in human newborns. Following meconium instillation in one lung lobe and mechanical ventilation of $12 \mathrm{~h}$ the total cell count was $1,400 \pm$ $1,100 / \mu \mathrm{l}$ in 17 piglets at day $0-2$ of life (Korhonen et al., 2004). Likewise PMNL was the dominating cell line $(1,000 \pm 900 / \mathrm{ml})$ as also seen in our model $(80 \pm 4 \%)$ (Figure 1).
PMNL, monocytes, and lung macrophages express CD14 implicated in the cellular response to LPS (given intratracheally as part of the triple-hit lung injury protocol applied here) together with a plasma LPS-binding protein. MD-2 and the intracellular part of TLR4 are necessary for the transduction of the signal activating cytokine and chemokine genes. The $\beta 2$-integrin CD18 is also expressed by both, PMNL and monocytes/macrophages, and plays an important role in the migration of cells to areas of the lung containing high concentrations of chemokines, such as C5a. Monocytes recruited into the alveolar space keep phenotypic features of blood monocytes but upregulate CD14 resulting in enhanced responsiveness to LPS with increased cytokine expression (Maus et al., 2001). $28 \pm 15 \%$ of the cells harvested by BALF (Table 7) are CD14 $4^{+} / 18^{+}$and belong to either population; their response to LPS and the concomitant (overwhelming) production of TNF- $\alpha$, IL- $1 \alpha$ and IL-1 $\beta$, IL-6, IL-8, C3a, and C5a (Billman Thorgersen et al., 2009) represents a major proinflammatory pathway in the ARDS lung (Dentener et al., 1993). An important difference in physiologic response of the porcine lung to a variety of agents, such as particulates, bacteria, fibrin, cellular debris, and immune cells are constitutive pulmonary intravascular macrophages (PIM) that express a $\beta 3$ integrin subunit (CD61) for the clearance of all kinds of proteins from the circulation (Schneberger et al., 2012). The heavy accumulation of PIM in lung tissue is linked with an increase in vascular permeability, edema, hemorrhage, and alveolar septal thickening 
TABLE 5 | Bacteria in airways.

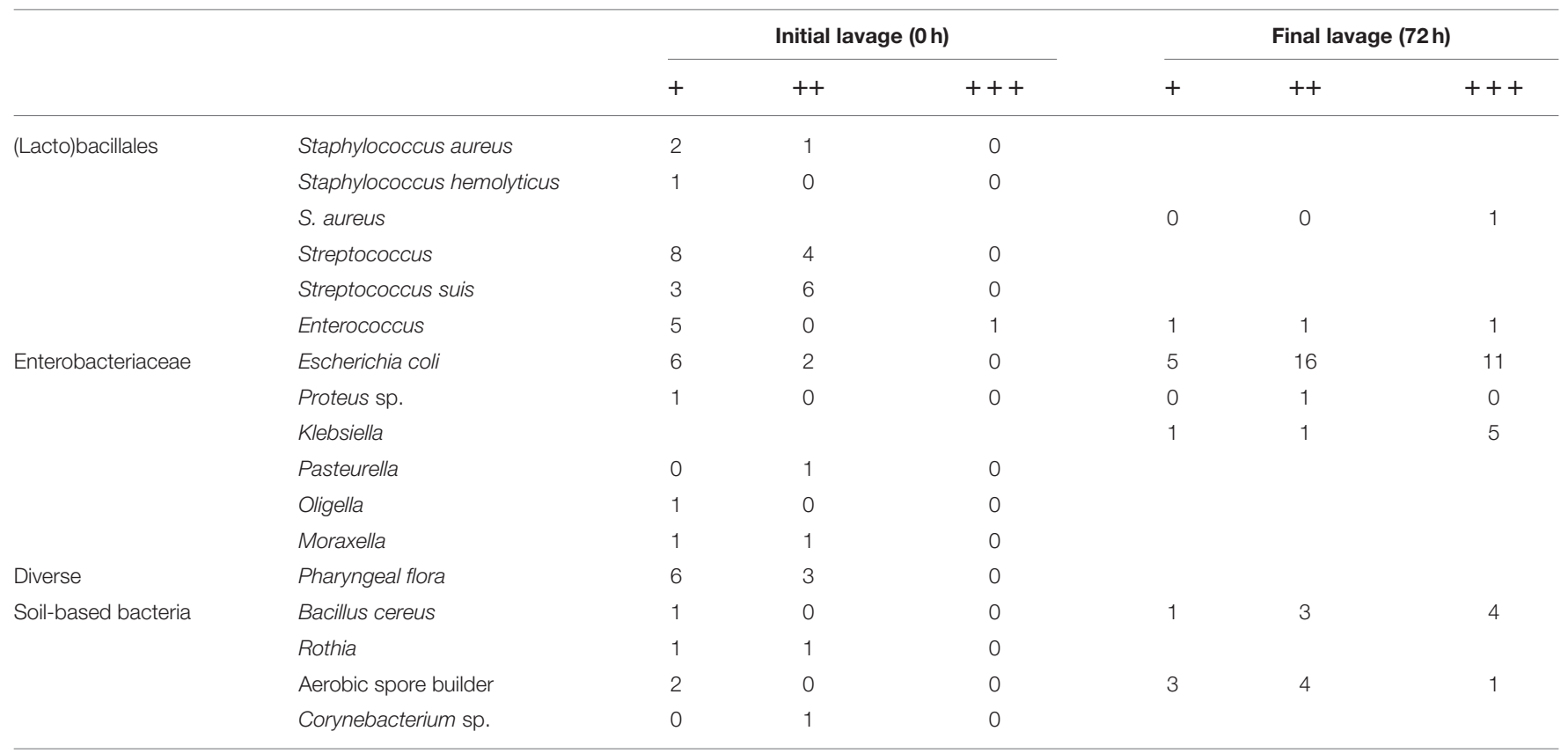

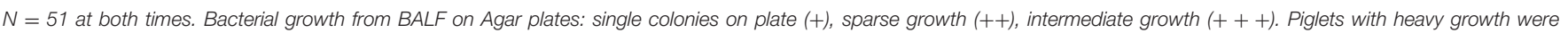

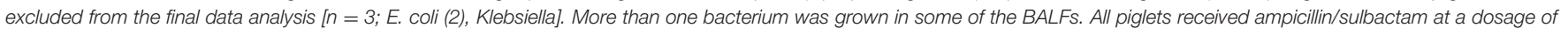
$100 \mathrm{mg} / \mathrm{kg}$ twice a day. Overgrowth of E. coli, Klebsiella, Bacillus cereus, and aerobic spore builders due to natural or acquired resistance.

TABLE 6 | Lung and body weights.

\begin{tabular}{|c|c|c|c|c|c|}
\hline & $\mathrm{HC}_{0}$ & $\mathrm{C}_{72}$ & $T_{72}$ & $\mathrm{HC}_{0}$ vs. $\mathrm{C}_{72}$ & $C_{72}$ vs. $T_{72}$ \\
\hline Lung weight (g) & $40 \pm 4$ & $75 \pm 8$ & $69 \pm 9$ & $<0.0001$ & 0.13 \\
\hline Body weight (kg) & $2.4 \pm 0.2$ & $2.3 \pm 0.1$ & $2.3 \pm 0.1$ & 0.29 & 0.38 \\
\hline Body weight gain (kg) & - & $0.15 \pm 0.04$ & $0.11 \pm 0.05$ & - & 0.05 \\
\hline Lung/body weight (\%) & $1.6 \pm 0.2$ & $3.2 \pm 0.4$ & $2.9 \pm 0.4$ & $<0.0001$ & 0.07 \\
\hline
\end{tabular}

$\mathrm{HC}_{0}$, healthy controls at $\mathrm{h}$; $\mathrm{C}_{72}$, controls at $72 \mathrm{~h} ; \mathrm{T}_{72}$, treated at $72 \mathrm{~h}$; body weight gain, weight gain within $72 \mathrm{~h}$ of mechanical ventilation including triple-hit lung injury.

Data are mean $\pm S D$. Number of piglets included: $H C_{0}=8$, control $=8$, treat(ment) $=43$. Comparison by $t$-tests.

(Figure 1) in a piglet model of classical swine fever (Núnez et al., 2018).

Alveolar epithelial apoptosis is a typical feature of the ARDS lung (15.0 $\pm 5.8 \%$, Table 7) and is linked with impairment of oxygenation and ventilation and abrogated barrier functions (Matute-Bello and Martin, 2003). In pediatric patients dying from PARDS the extent of cleaved caspase- 3 in alveolar epithelial cells as a surrogate parameter of apoptosis has been quantified by Bern et al. (2010) yielding a percentage of $6.4 \pm 1.2$ (range 1.018.1)\%. Apoptosis in severe lung disease must be differentiated from apoptosis during the process of alveolarization and differentiation which continues after birth until the second year of life; thus background apoptosis of $1-2 \%$ of AEC must be considered in neonatal organisms when evaluating lung disease (del Riccio et al., 2004). In ARDS the percentage of apoptotic PMNL obtained by lavage was $3(0-7.3) \%$ in patients who died (Matute-Bello et al., 1997), and 10-20\% in a murine ARDS model of intraperitoneal LPS (data on human or porcine neonates unknown) (Wang et al., 2014). Data on macrophage apoptosis are scarce and increase from $10.1 \pm 1.1 \%$ to $20.2 \pm 1.7$ following LPS challenge in murine cell cultures (Li et al., 2018).

\section{Surfactant Surface Tension and Alveolo-Capillary Leakage}

Regardless of the kind of acute lung injury the surfactant surface tension (Table 8) will increase considerably due to either a loss of the surfactant pool (repeated airway lavage) or disturbances in surfactant function (meconium instillation, LPS instillation, hyperoxia). In a meconium aspiration model minimum surfactant surface tension increased from $17.8 \pm$ $4.8 \mathrm{mN} / \mathrm{m}$ to $23.3 \pm 4.8$ (Wiswell et al., 1994), and in a repeated airway lavage model from $11.1 \pm 5.2$ to $21.8 \pm 2.1$ (von Bismarck et al., 2007). Albumen has been identified as a major factor of surfactant inhibition (Seeger et al., 1993) and simultaneously reflects the degree of capillary-alveolar leakage as part of the inflammation of lung tissue and pulmonary capillaries. Albumen concentrations in BALF have been assessed in a hyperoxia model with baseline values of $56 \pm 19 \mu \mathrm{g} / \mathrm{ml}$ 
TABLE 7 | Cells in BALF and apoptosis.

\begin{tabular}{|c|c|c|c|c|c|}
\hline & Total $_{0}$ & $\mathrm{C}_{72}$ & $\mathbf{T}_{72}$ & Totalo vs. $\mathbf{C}_{72}$ & $\mathrm{C}_{72}$ vs. $\mathrm{T}_{72}$ \\
\hline Total cells (cells/ $\mu \mathrm{l})$ & $633 \pm 336$ & $1,624 \pm 1,003$ & $1,059 \pm 786$ & $<0.0001$ & 0.07 \\
\hline PMNL (\%) & $32 \pm 14$ & $80 \pm 4$ & $79 \pm 7$ & $<0.0001$ & 0.95 \\
\hline Lymphocytes (\%) & $3.2 \pm 3.2$ & $1.9 \pm 1.0$ & $1.9 \pm 0.9$ & 0.13 & 0.97 \\
\hline Monocytes/macrophages (\%) & $64 \pm 15$ & $17 \pm 4$ & $18 \pm 7$ & $<0.0001$ & 0.89 \\
\hline $\mathrm{CD}^{+} 4^{+} / 18^{+}(\%)$ & $28 \pm 15$ & $64 \pm 15$ & $59 \pm 25$ & 0.003 & 0.94 \\
\hline Apoptotic PMNL (\%) & $10.2 \pm 8.3$ & $16.2 \pm 6.6$ & $11.2 \pm 5.9$ & 0.04 & 0.08 \\
\hline Apoptotic macrophages (\%) & $10.5 \pm 11.1$ & $54.8 \pm 24.6$ & $48.3 \pm 20.8$ & 0.0004 & 0.44 \\
\hline Apoptotic AEC (\%) & $15.0 \pm 5.8$ & $15.0 \pm 5.6$ & $13.9 \pm 5.7$ & 1.00 & 0.68 \\
\hline
\end{tabular}

BALF, broncho-alveolar lavage fluid; PMNL, polymorpho-nuclear leukocytes; AEC, alveolar epithelial cells.

Totalo, all piglets at $\mathrm{O}$; $\mathrm{C}_{72}$, controls at $72 \mathrm{~h} ; \mathrm{T}_{72}$, treated piglets at $72 \mathrm{~h}$.

Data are mean $\pm S D$. Number of piglets included: Total $0=51$, control $=8$, treat(ment) $=43$. Comparison by $t$-test for total cells, and by Mann-Whitney tests for all other parameters.

and a 3-fold increase following lung injury (Davis et al., 1989). SP-D serum concentrations in ARDS increased 3- to 4-fold [from $1.9 \mu \mathrm{g} / \mathrm{ml}(0.6-4.4)$ to 5.9 (2.5-22.7) (Yang et al., 2017); and from $83 \pm 33 \mathrm{ng} / \mathrm{ml}$ to $476 \pm 391$ (Endo et al., 2002)]. SPLA $_{2}$ has been blamed to play a major role in surfactant degradation in NARDS lungs (De Luca et al., 2017) as evidenced in 10 neonates with severe sepsis/pneumonia [control: $0.5 \mathrm{IU} / \mathrm{ml}$ (0.1-3.1), nARDS: 4.0 (2.1-8.5)] (De Luca et al., 2008). Not surprisingly, sPLA 2 also plays an important role in PARDS (infants between 2 and 10 months of age) with activities being increased by factor three compared to control groups and with significant correlation of $\mathrm{PLA}_{2}$ changes and changes in free fatty acid concentrations in BALF; in addition, TNF- $\alpha$ concentrations, surfactant phospholipids, and surface tension from epithelial lining fluid were correlated to $\mathrm{SPLA}_{2}$ variations (De Luca et al., 2011, 2013). BALF SP-A levels remained almost constant in a piglet model of repeated airway lavage and the installation of group B streptococci into the airways [healthy: $80 \pm 43$ $\mathrm{pg} / \mathrm{ml}$, treat $74 \pm 34$ (van Kaam et al., 2004b)], as there were no significant differences in SP-A gene expression in alveolar epithelial cells between aARDS and control patients (Pires-Neto et al., 2013).

\section{NF- $\kappa B$, Inflammasome, and Ceramide Pathway}

In an experimental pneumonia model with $E$. coli instilled into the airways of 3-4 weeks old piglets the NF- $\kappa \mathrm{B}$ concentration in lung tissue homogenates increased from 0.25 to 0.4 arbitrary units and could be reduced by the application of inhaled nitric oxide or the instillation of surfactant (Zhu et al., 2005). The selective topical inhibition of NF- $\mathrm{B}$ by IKK-NBD peptide via instillation into the airways using surfactant as a carrier substance improved FRC, $\mathrm{V}_{\mathrm{A}}, \mathrm{C}_{\mathrm{rs}}, \mathrm{R}_{\mathrm{rs}}$, and EVLWI in a newborn piglet lavage model (Ankermann et al., 2005a; von Bismarck et al., 2007). Of note, the reduction of NF- $\kappa \mathrm{B}$ activity in the nucleus of pulmonary cells from $100 \pm 2 \%$ to $32 \pm 2$ by IKK-NBD peptide was more pronounced than the effect of dexamethasone reaching an activity of only $55 \pm 4 \%$ (von Bismarck et al., 2009).

In porcine alveolar macrophages swine influenza virus induces massive IL-1 $\beta$ production secondary to an increased expression of inflammasome components (NLRP3, ASC, procaspase-1)
(Park et al., 2018). In C57BL/6 mice the application of a twohit lung injury by mechanical ventilation and LPS induces IL-1 $\beta$ and KC (a murine functional analog of IL-8), and cell migration into the alveolar space, all of which may be considerably reduced by the administration of the IL-1 antibody anakinra (Jones et al., 2014). NLRP ${ }^{-/-}$mice exposed to hyperoxia showed significantly lower IL- $1 \beta$, TNF- $\alpha$, and MIP-2 concentrations in BALF (Fukumoto et al., 2013). The mutual dependency of the ceramide pathway and the inflammasome NLRP3 has been shown by Kolliputi and our group in alveolar epithelial cells (Kolliputi et al., 2012) and in porcine lung homogenates (Spengler et al., 2018) (Table 9). In tracheal aspirates from preterm infants prone to bronchopulmonary dysplasia (BPD) high IL-1 $\beta$ and IL-1ra concentrations were linked with more severe grades of BPD or death (Liao et al., 2018). In adult patients subject to overventilation $\left(\mathrm{V}_{\mathrm{T}}=12 \mathrm{ml} / \mathrm{kg}\right)$ ASCupregulation in alveolar epithelial cells was $\sim 10$-fold compared to normoventilation, the expression of NLRP3 and ASC in alveolar macrophages doubled (Kuipers et al., 2012). The NLRPdependent cytokine IL-1 $\beta$ was treated with either aerosolized or intravenous anakinra in a lavage model of surfactant depletion yielding moderately improved oxygenation, ventilation, $\mathrm{C}_{\mathrm{rs}}$, and neutrophil migration into lung tissue (Chada et al., 2008). The IL- $1 \beta / \beta$-actin ratio in lung tissue was reduced from $4.9 \pm 2.4$ (control) to $0.9 \pm 0.3$ (aerosolized) and $0.8 \pm 0.1$ (intravenous), respectively. A comparable reduction in the $\mathrm{IL}-8 / \beta$-actin ratio could be demonstrated. In an E. coli LPS model of ARDS treating 4-6 weeks old piglets by the intravenous route, IL-1 $\beta$ concentrations rose from $29 \pm 2 \mathrm{pg} / \mathrm{ml}$ to $89 \pm 18$, IL-6 from $18 \pm 8 \mathrm{pg} / \mathrm{ml}$ to $22 \pm 7$, and IL- 8 from $80 \pm 7 \mathrm{pg} / \mathrm{ml}$ to $118 \pm 10$ (Wang et al., 2016).

"Ceramide lances the lungs," as pointed out by P. Barnes (Barnes, 2004) describes the impact of the activated ceramide pathway on impairment of alveolo-capillary barrier functions in lung inflammation (Göggel et al., 2004). More than 30 years ago high concentrations of galactosylceramide (20- to 40 -fold normal) were found in the lavage fluid of mechanically ventilated ARDS patients (Rauvala and Hallman, 1984). In (adult) patients suffering from cystic fibrosis the application of amitriptyline normalizes pulmonary ceramide and improves lung function including susceptibility to infection (Teichgräber et al., 2008). 
A

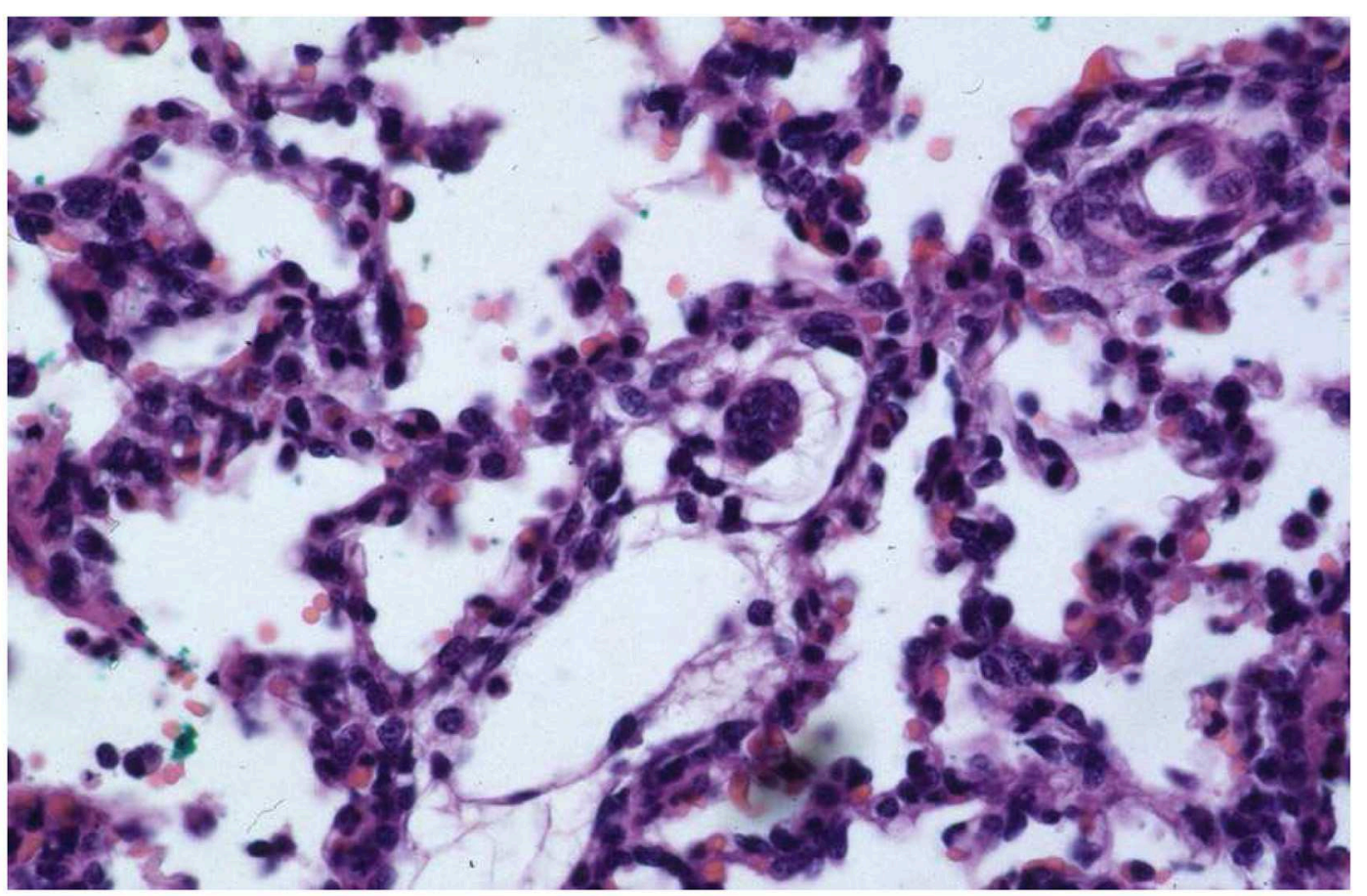

B

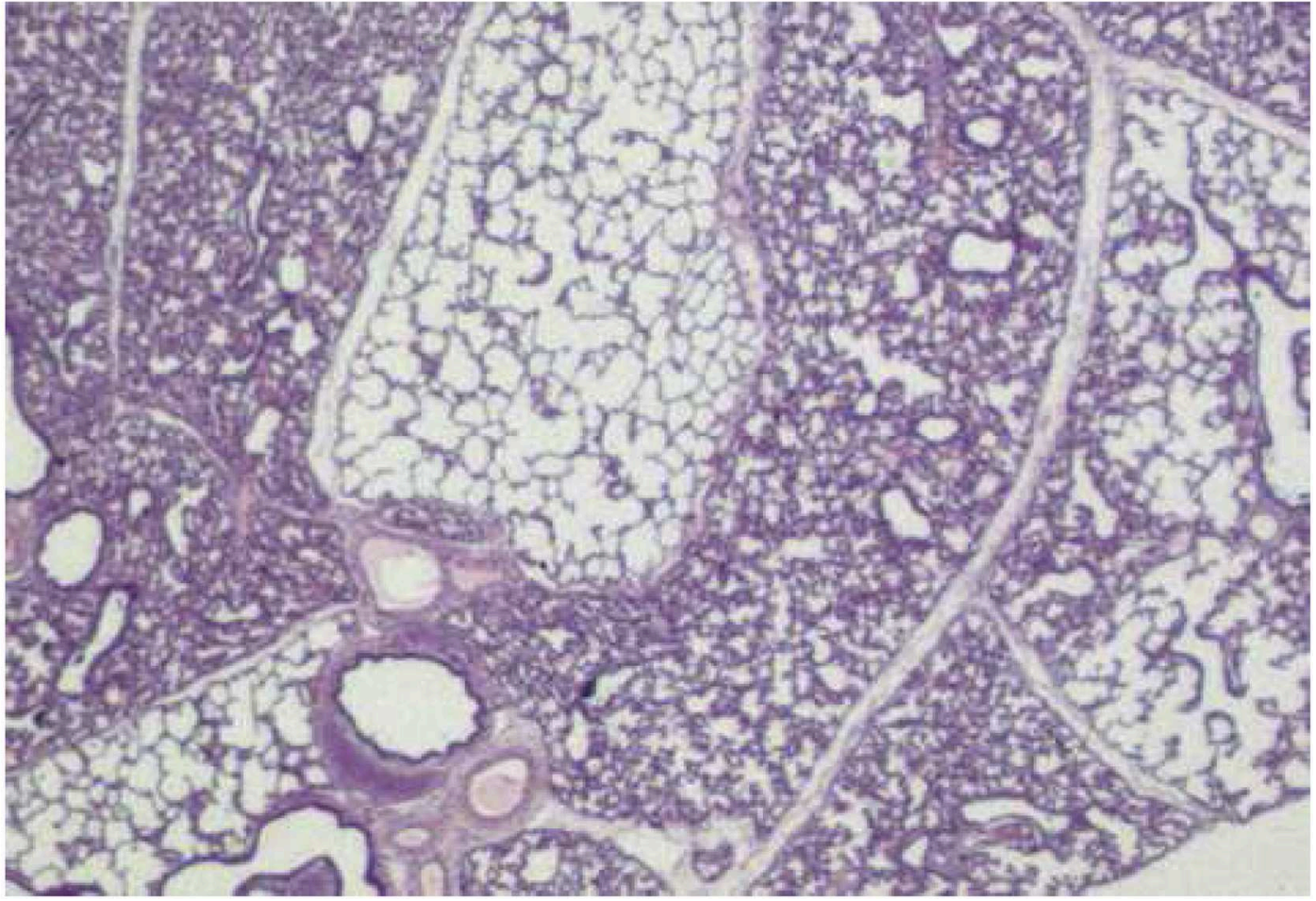

FIGURE 1 | Microscopic findings of a control piglet after $24 \mathrm{~h}$ of mechanical ventilation following repeated airway lavage. (A) Diffuse alveolar collapse next to overdistention, severely thickened alveolar septae. Some hyaline membrane formation and alveolar basement denudation is evident. Abundant cellular infiltration with PMNL and macrophages in the pulmonary interstitium and in the alveolar spaces. Infiltrations with red blood cells as sign of diffuse pulmonary hemorrhage and coagulation activation. (B) Lobuli with alveolar collapse adjacent to overdistention containing proteinaceous alveolar edema. Hematoxylin and eosin staining, oil $x$ 1,200 (A), $\times 300$ (B) 
TABLE 8 | Surfactant surface tension and alveolar-capillary leakage.

\begin{tabular}{|c|c|c|c|c|c|}
\hline & Total $_{0}$ & $\mathrm{C}_{72}$ & $\mathbf{T}_{72}$ & Total $_{0}$ vs. $\mathrm{C}_{72}$ & $C_{72}$ vs. $T_{72}$ \\
\hline Surfactant surface tension (m/Nm) & $21 \pm 2$ & $41 \pm 14$ & $28 \pm 8$ & 0.0004 & 0.001 \\
\hline $\mathrm{sPLA}_{2}$ in BALF $(\mathrm{ng} / \mathrm{ml})$ & $20 \pm 10$ & $28 \pm 11$ & $14 \pm 10$ & 0.06 & 0.006 \\
\hline Albumen in BALF $(\mu \mathrm{g} / \mathrm{ml})$ & $111 \pm 25$ & $378 \pm 36$ & $275 \pm 115$ & $<0.0001$ & 0.015 \\
\hline SP-A in BALF (\%) & $100 \pm 3$ & $68 \pm 35$ & $82 \pm 35$ & $<0.0001$ & 0.285 \\
\hline SP-D in serum (ng/ml) & $56 \pm 3$ & $326 \pm 19$ & $220 \pm 101$ & $<0.0001$ & 0.005 \\
\hline
\end{tabular}

Surfactant surface tension, minimum surface tension of $10 \mathrm{mg}$ surfactant in $1 \mathrm{ml}$ BALF measured by a Wilhelmy balance; $S P L A_{2}$, secretory phospholipase $A_{2}$; SP-D, surfactant protein $D$. Data are mean $\pm S D$. Totalo, all piglets at $0 \mathrm{~h} ; \mathrm{C}_{72}$, controls at $72 \mathrm{~h} ; T_{72}$, treated piglets at $72 \mathrm{~h}$. Number of piglets included: totalo $=51$, control $=8$, treat (ment) $=43$. Comparisons by t-tests (SP-A by Mann-Whitney test).

TABLE 9 | NF-kB, inflammasome, and ceramide pathways.

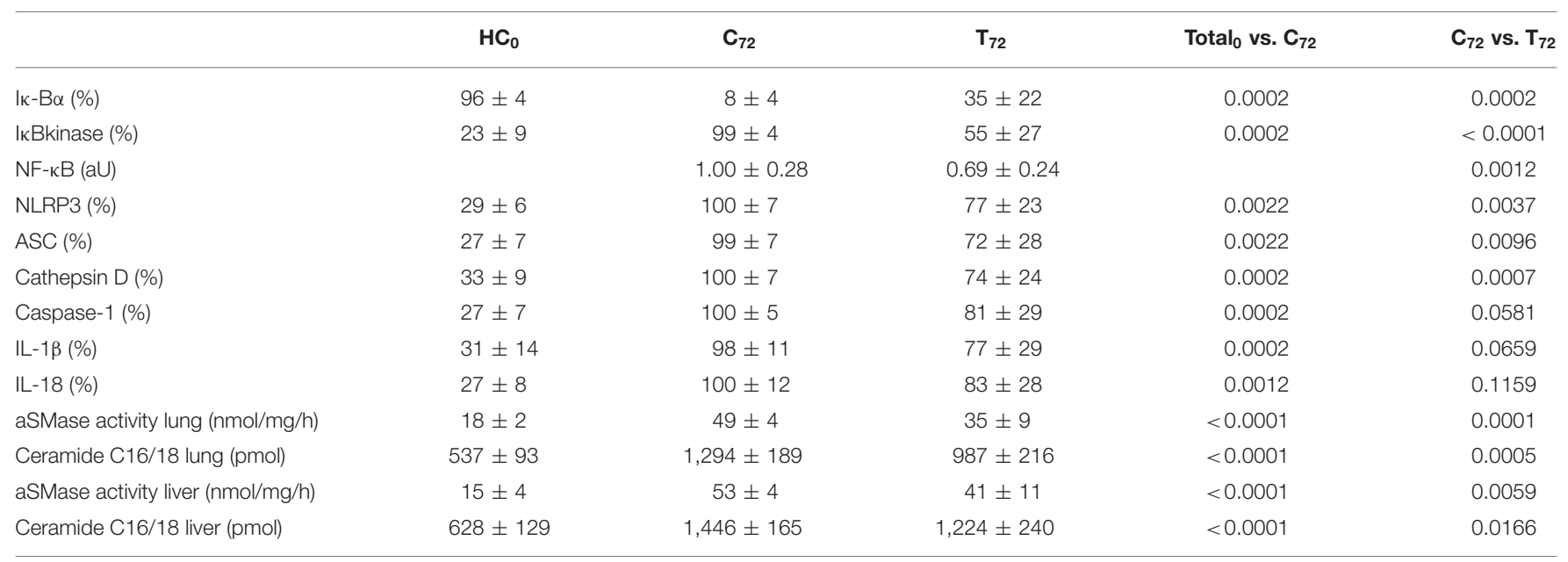

$I_{k}-B \alpha$, inhibitor of NF- $\mathrm{kB}$ release and translocation; I $\mathrm{k} B$ kinase, kinase of $/ \mathrm{k}-B \alpha$; aU, arbitrary units for C24 and T24; NLRP3, inflammasome nucleotide-binding domain-leucine-rich repeat-containing protein-3; ASC, apoptosis-associated speck-like protein containing a caspase recruitment domain; aSMase, acid sphingomyelinase.

$H C_{0}$, healthy controls at $\mathrm{O} h ; \mathrm{C}_{72}$, controls at $72 \mathrm{~h} ; \mathrm{T}_{72}$, treated piglets at $72 \mathrm{~h}$.

Data are mean $\pm S D$. Number of piglets included: total $=51$, control $=8$, treat $=43$ (NF-kB: $\left.C_{72}=7, T_{72}=15\right)$. Comparisons by Mann-Whitney tests for NF-kB and inflammasome parameters, by unpaired $t$-tests for ceramide parameters.

As it is well-known for many years that the porcine organism displays all kinds of glycolipids, such as galactosylceramide, glucosylceramide, ganglioside, and globoside (Kyogashima et al., 1989) there is unfortunately no data for comparing our results with regard to the impact of the acid sphingomyelinase/ceramide pathway on lung function. For the rat it has been shown that sphingomyelin content, sphingosine concentrations, and ceramide concentrations are highest in neonatal compared to fetal or adult lungs (Longo et al., 1997) underlining the important role of the ceramide pathway in neonatal lung physiology. In the newborn rat (Husari et al., 2006) and newborn mice (Tibboel et al., 2013) hyperoxia models, ceramide and sphingomyelin concentrations are increased 2- to 4-fold. In addition stretch applied to alveolar epithelial cells from newborn rat lungs by mechanical ventilation induces autophagy, acid sphingomyelinase activity, and ceramide generation (Yeganeh et al., 2018).

\section{Pro-fibrotic and Pro-inflammatory Parameters}

TNF- $\alpha$ in BALF (Table 10) increased from $21 \pm 4 \mathrm{pg} / \mathrm{ml}$ to $42 \pm 22$ following meconium instillation into the lungs of 12 days old piglets (Korhonen et al., 2004), from $0.03 \pm 0.02$
$\mathrm{U} / \mathrm{ml}$ to $0.34 \pm 0.58$ in a newborn piglet lavage model (Krause et al., 2005), and from $80 \pm 84 \mathrm{pg} / \mathrm{ml}$ to $1,357 \pm 676$ in a meconium model with 1-3 days old piglets (Angert et al., 2007). Depending on the kind of acute lung injury the increasing pre/post-injury factor varies largely between 1:2 and 1: 60 (Table 10). IL- 8 concentrations rose from $51 \pm 34 \mathrm{pg} / \mathrm{ml}$ to $429 \pm 259$ in a lavage model (Ankermann et al., 2005b), and from $406 \pm 364$ $\mathrm{pg} / \mathrm{ml}$ to $4,837 \pm 1,951 \mathrm{in}$ an meconium aspiration model (Angert et al., 2007), whereas IL-6 from BALF came up from $0.4 \pm 1.0$ $\mathrm{U} / \mathrm{ml}$ to $29 \pm 28$ following repeated airway lavage (Krause et al., 2005). $\mathrm{LTB}_{4}$ as an important chemokine in the inflamed lung and increased from $2.6 \pm 1.9 \mathrm{pg} / \mathrm{ml}$ to $9.3 \pm 7.8$ in a newborn lavage model (Ankermann et al., 2005a).

Data from other authors on fibrosis in (newborn and adult) piglets subject to induced acute lung injury are missing probably due to the observation interval of at least $24-72 \mathrm{~h}$ before changes in pro-fibrotic parameters may be quantified as demonstrated in ARDS patients (Fahy et al., 2003; Fligiel et al., 2006). A $72 \mathrm{~h}$ model of clinical observation as presented here (Preuß et al., 2012b; Spengler et al., 2018) is expensive and requires detailed knowledge of neonatal physiology and intervention skills. However, as an exception, von der Hardt et al. presented TGF- $\beta$ mRNA expression data in a piglet lavage 
TABLE 10 | Pro-fibrotic and pro-inflammatory parameters.

\begin{tabular}{|c|c|c|c|c|c|}
\hline & Total $_{0}$ & $\mathrm{C}_{72}$ & $\mathbf{T}_{72}$ & Total $_{0}$ vs. $\mathbf{C}_{72}$ & $\mathrm{C}_{72}$ vs. $\mathrm{T}_{72}$ \\
\hline TGF- $\beta$ (\%) & $20 \pm 15$ & $103 \pm 2$ & $84 \pm 31$ & 0.0079 & 0.0747 \\
\hline $\mathrm{IFN}-\gamma(\%)$ & $26 \pm 14$ & $100 \pm 13$ & $76 \pm 29$ & 0.0022 & 0.0571 \\
\hline Elastin (\%) & $48 \pm 7$ & $101 \pm 5$ & $74 \pm 21$ & 0.0002 & 0.0004 \\
\hline MMP-1 (\%) & $45 \pm 7$ & $101 \pm 6$ & $68 \pm 22$ & 0.0002 & 0.0003 \\
\hline IL-8 in BALF $(\mathrm{pg} / \mathrm{ml})^{\star}$ & & $455 \pm 320$ & $90 \pm 101$ & & 0.0018 \\
\hline IL-6 in BALF $(\mathrm{pg} / \mathrm{ml})^{\star}$ & & $56 \pm 14$ & $19 \pm 3$ & & $<0.0001$ \\
\hline $\mathrm{LTB}_{4}$ in BALF $(\mathrm{pg} / \mathrm{ml})^{\star}$ & & $95 \pm 72$ & $45 \pm 21$ & & 0.0267 \\
\hline TNF- $\alpha$ in BALF (pg/ml) & $2 \pm 6$ & $117 \pm 119$ & $70 \pm 66$ & $<0.0001$ & 0.1425 \\
\hline
\end{tabular}

TGF- $\beta$, transforming growth factor- $\beta$; IFN- $\gamma$, interferon- $\gamma$; MMP-1, matrix metalloproteinase 1; $L T B_{4}$, leukotriene $B_{4}$.

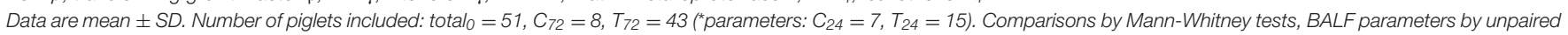
t-tests. ${ }^{*}$ Parameters measured at $C_{24}$ and $T_{24}$.

model unfortunately not yielding an adequate control group (von der Hardt et al., 2002). The variation of TGF- $\beta$ between the four intervention groups in this study was not surprisingly very small $(1.30 \pm 0.11$ to $1.79 \pm 0.20$ relative units) suggesting an inadequate observation time of $8 \mathrm{~h}$ only. TGF- $\beta 1$ and its isoforms is constitutively stored by mammalian cells, may be released upon integrin signaling, and induce alveolar epithelial cell differentiation into (myo)fibroblasts which avidly produce collagen and elastin as part of the intermediate fibrotic stage in ARDS. Next to TGF- $\beta 1$ and IFN- $\gamma$ signaling the matrix metalloproteinase MMP-1 (in contrast to MMP-2, MMP-8, and MMP-9) plays a distinct role in fibrosis as high concentrations in BALF may discriminate patients surviving or not surviving ARDS (Fligiel et al., 2006).

\section{Systematic Review}

The systematic review (flowsheets in Figure 2) highlights two major acute direct lung injury models with the need of mechanical ventilation in term newborn piglets $<14$ days of age. Thus, gradually developing lung injury models, such as hyperoxia application or lung injury models without mechanical ventilation are not covered here. For a better understanding of NARDS immunologic outcome parameters and the effect of specific interventions are displayed.

\section{Meconium Aspiration Model}

The meconium aspiration model is a frequently used model of direct lung injury by the installation of (human) diluted meconium into the airways. Within $2 \mathrm{~h}$ following meconium instillation, an increase in $\mathrm{OI}$ and $\mathrm{R}_{\mathrm{rs}}$ and a decrease in $\mathrm{sC}_{\mathrm{rs}}$ by $\sim 50 \%$ can be observed (Kuo and Chen, 1999; Tølløfsrud et al., 2002). BP, CI and SVRI do not change significantly compared to control groups whereas the pulmonary arterial pressure (PAP) and the pulmonary vascular resistance index (PVRI) differ beyond a $2 \mathrm{~h}$ margin (Trindade et al., 1985; Kuo and Chen, 1999; Ryhammer et al., 2007). Of note, the deteriorations in lung mechanics and gas exchange are not sustained evaluating studies with longer observation periods (i.e., 12-48 h) when inflammatory parameters start to gradually decline again (Davey et al., 1993; Korhonen et al., 2004).
Meconium is composed of a myriad of substances essentially containing gastrointestinal secretions, bile, bile acids, pancreatic juice, mucus, swallowed vernix caseosa, lanugo hair, cellular debris, and blood (van Ierland and de Beaufort, 2009). As meconium is located "extracorporally" (i.e., hidden in the intestinal tract) its content normally is not recognized by the fetal immune system (Lindenskov et al., 2015). However, once meconium enters the airways the innate immunity senses a "damaged self" and reacts with "chemical pneumonitis" including increased airway responsiveness, pulmonary hypertension, cellular infiltration, impairment of gas exchange, PMNL infiltration of airways and lung tissue, alveolar epithelial cell apoptosis, and a cytokine storm (Lindenskov et al., 2005).

Therefore, aspects most often studied in the newborn piglet meconium aspiration model are cytokines/chemokines, PMNL infiltration (by the quantification of myeloperoxidase (MPO) in BALF and in lung tissue by immunohistochemistry), reactive oxygen species (ROS), pulmonary hypertension, arachidonic acid metabolites (notably sPLA 2 ), and changes of the complement system (membrane attack protein sC5b-9).

Many studies quantified cytokines/chemokines, such as IL-1 $\beta$, IL-6, IL-8, and TNF- $\alpha$ (Table 11) all of which largely depend on pattern recognition by the Toll-like receptor family (especially TLR4/MD-2, CD14, and C5a) (Salvesen et al., 2010). Specific therapy assessment to influence e.g., CD14 (Thomas et al., 2018) and downstream NF- $\kappa$ B by broad-acting glucocorticoids (Holopainen et al., 2001; Lin et al., 2016, 2017) or more specific inhibitors of NF- $\kappa \mathrm{B}$ are scarce and deserve further evaluation.

ROS are inflammatory mediators protecting the host from external damage, however, they simultaneously inherit a strong potential to harm the host in case of overwhelming activation. The complement system is linked with C5a-mediated leukocyte oxidative burst (Castellheim et al., 2005) and plays an important role by the supply of C5b-9 which has the potential to also directly attack alveolar epithelial cells. While the combined application of C5a- and CD14-inhibitors resulted in a pronounced attenuation of inflammatory parameters (particularly IL-1 $\beta$ and MPO), the clinical course of the intervention group was not different from the control group (Thomas et al., 2018). 


\section{A Meconium aspiration model}

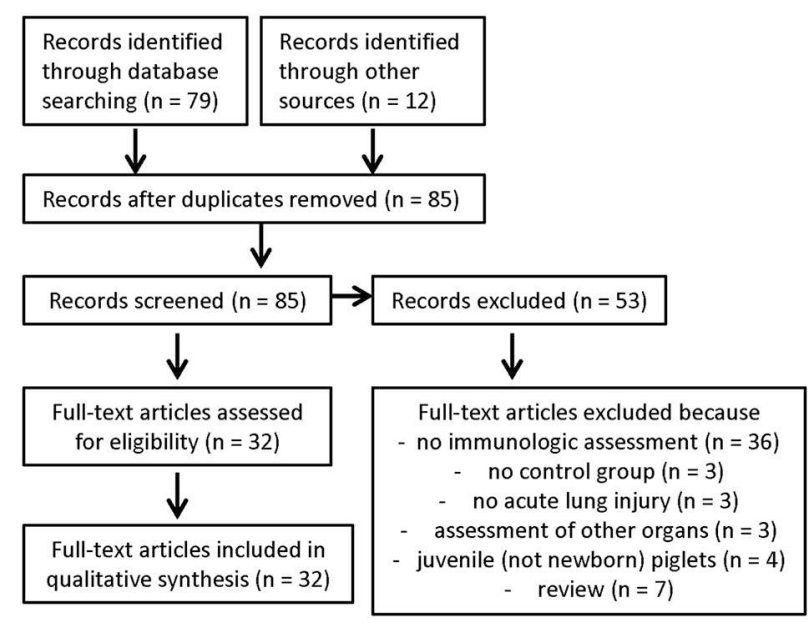

\section{B Lavage model}

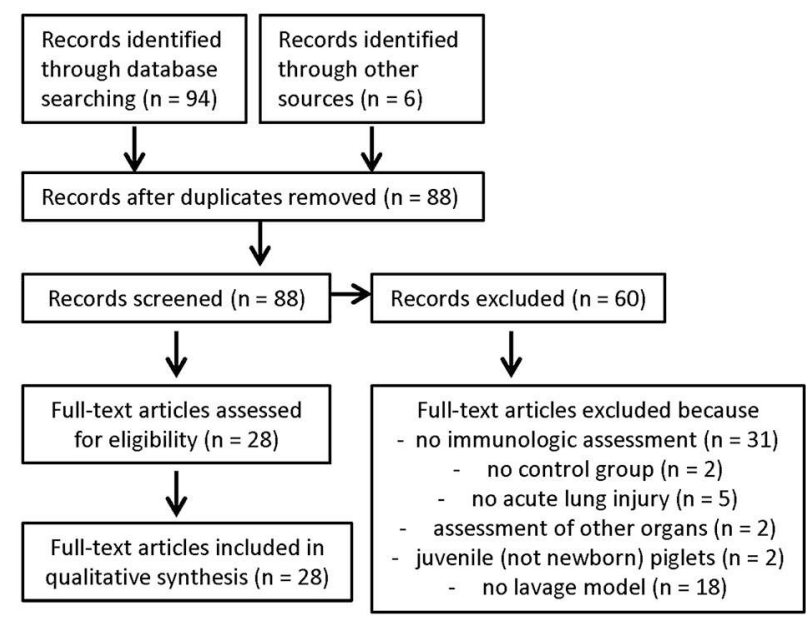

FIGURE 2 | Flow sheets of the systematic review of the meconium aspiration model $(\mathbf{A})$ and the lavage model $(\mathbf{B})$.

Meconium has high concentrations of phospholipase $\mathrm{A}_{2}$ $\left(\mathrm{sLA}_{2}\right)$, a family of ubiquitous enzymes that release arachidonic acid by the cleavage of membrane phospholipids or surfactant (Holopainen et al., 1999a; De Luca et al., 2009). The administration of dexamethasone which reduces a stimulated sPLA $_{2}$ synthesis (Hoeck et al., 1993), does not contain sPLA 2 activity nor reduce inflammation in the newborn piglet model (Holopainen et al., 2001).

By far the majority of the studies (Table 11) focus on the effect of surfactant substitution for improvements in lung mechanics and gas exchange. While surfactant is known to protect the lungs from inflammation modulating peroxidation, formation of nitric oxide, $\mathrm{sPLA}_{2}$, eicosanoids, and cytokines (Wright,
2003), some surfactant fractions, such as palmitoyl-oleoylphosphatidylglycerol (POPG) (Numata et al., 2010; Spengler et al., 2018) and dioleoyl-phosphatidylglycerol (DOPG) (Preuß et al., 2014) exert potent anti-inflammatory action and deserve further research (Salvesen et al., 2014). The administration of a POPG-based synthetic surfactant (CHF5633), however, did not improve the clinical outcome in the newborn piglet model not reflecting some marked inflammatory mediator attenuations, such as reductions in IL-1 $\beta$ and lipid peroxidation (Salvesen et al., 2014).

\section{Lavage Model}

The lavage model (Table 12) excels by the fine-tuning of impairment of gas exchange (oxygenation index, ventilation efficiency index), lung mechanics (compliance and resistance of the respiratory system), and lung volumes (alveolar volume, functional residual capacity). Once an appropriate lung injury has been set (mostly monitored by reductions of oxygenation and compliance) the piglet remains stable with regard to circulation and other organ system function. By the use of continuous sedation/analgesia, mechanical ventilation can be perpetuated for several days allowing further injury to the lungs (double-/triple hit injury models) or specific interventions. That way, the requirements for NARDS by the Montreux definition (acute onset; diffuse, bilateral, irregular opacities; edema; oxygenation deficit) can be completely satisfied (De Luca et al., 2017). In addition, as an animal model of acute lung injury, physiologic changes (decreased compliance, reduced functional residual capacity, V/Q-abnormalities, impaired alveolar fluid clearance), biological changes (increased endothelial and epithelial permeability, increased cytokine concentrations in BALF or lung tissue, protease activation, coagulation abnormalities), and pathological changes (infiltration by PMNL, fibrin deposition and augmented intra-alveolar coagulation, denudation of the basement membrane) can be observed (Matute-Bello et al., 2008).

The washout of endogenous surfactant by the use of warmed normal saline with a volume exceeding FRC (i.e., $>25 \mathrm{ml} / \mathrm{kg}$ ) ensures-in contrast to other models-acute onset of NARDS which is sustained by secondary damage to the remaining surfactant within the lung and the triggering of a marked inflammatory response which primarily activates all mechanisms of the innate immunity. Thus, the saline for lavage may be considered as a pathogen-associated molecular pattern (PAMP) being recognized by the collectin, ficolin, and pentraxin families which can act as opsonins either directly or by activating the complement system (as also shown in the meconium aspiration model) (Male, 2006). The innate immunity's response brings leukocytes and plasma proteins to the site of (lung) tissue damage. The arrival of leukocytes in the lung depends on chemokines and adhesion molecules expressed by the pulmonary vasculature endothelium, by the alveolar epithelium, and by the activity of local macrophages. Notably TNF- $\alpha$, which is primarily produced by macrophages, induces the expression of adhesion molecules and chemokines, and may elicit the activation of NF$\kappa \mathrm{B}$ and apoptosis. Next to TNF- $\alpha, \mathrm{IL}-1 \beta$ plays an important part in the induction of adhesion molecules on the endothelium. 
In this context it is surprising that many aspects of dampening the innate immune system in the overwhelming response of the neonatal lung secondary to repeated airway lavage have not been studied yet (Table 12). While the early studies considering immunologic aspects measured protein content in BALF, histopathology scores, and the concentrations of TNF- $\alpha$, $\mathrm{LTB}_{4}$, IL-1 $\beta$, and MPO as a surrogate parameter for neutrophil infiltration (Sood et al., 1996a; Merz et al., 2002; van Kaam et al., 2005), more recent studies put light on the selective inhibition of NF- $\kappa$ B (von Bismarck et al., 2007), IL-1 $\beta$ metabolism (Chada et al., 2008), general immune suppression by dexamethasone or budenoside (von Bismarck et al., 2009; Yang et al., 2010), eicosanoid suppression (Ankermann et al., 2006), and blockade of IL-8 (Ankermann et al., 2005b). The impact of the ceramide metabolism in nARDS has been investigated (Barnes, 2004; von Bismarck et al., 2008; Spengler et al., 2018), and the important role of NLRP3 (nucleotide-binding domain, leucine-rich repeatcontaining protein-3) in a triple-hit lung injury model has been studied (Dos Santos et al., 2012; Spengler et al., 2018).

\section{Miscellaneous Models}

NARDS-like severe pneumonia has been established by few authors, however, the maintenance of $\mathrm{HR}$ and $\mathrm{BP}$ as prerequisite for a stable model of primary lung injury-in contrast to e.g., the rabbit model-can also be demonstrated in direct GBS instillation into the airways (van Kaam et al., 2004b). The selective inoculation of GBS into the lower lobes of newborn piglets resulted in widespread alveolar atelectasis, loss of hyaluronan, and an increased systemic uptake of the microorganisms into the circulation (Juul et al., 1996). Using isolated selectively perfused piglet lungs, an increase in total pulmonary resistance is observed following GBS-instillation into the pulmonary circulation (Aziz et al., 1993). Intravenous E. coli endotoxin has been used to induce a moderate impairment in oxygenation and lung mechanics without experiencing any positive changes by surfactant application (Sood et al., 1996b).

Moderately acute lung injury models involving mechanical ventilation have been established testing the effects of overventilation with and without the application of $100 \%$ O2 (Davis et al., 1989, 1991; Ehlert et al., 2006). Dexamethasone (Davis et al., 1995), G-CSF (Wolkoff et al., 2002), recombinant human Clara Cell protein 10 (rhCC10) intratracheally for hyperoxia (Chandra et al., 2003), and nitric oxide (NO) (Youssef et al., 1999) have been assessed using increased observation times for several days prior to mechanical ventilation.

An exceptional model of wood smoke inhalation treated with surfactant and partial liquid ventilation has been set up by Jeng et al. (2003).

\section{Perspective: Newborn Animal Models of NARDS Involving Mechanical Ventilation}

Many more newborn animal models from different species and subject to a variety of acute lung injury protocols have been set up (Table 13). While the clinical relevance varies considerably among species with regard to body size (piglets and lambs $70-80 \%$ of human size, rodents $0.1-1.6 \%$ ), availability, and similarities with the human innate immunity, models with rodents have been used abundantly for low costs and genetic similarity among animals despite of their limitations in comparability with human newborns. Ethical considerations and very high costs limit the availability of newborn baboons which have been studied almost exclusively in preterm models of infant respiratory distress syndrome (IRDS). Thus, piglet and lamb models clearly head the list of established newborn animal models of NARDS also considering the wide variety of direct and of only one direct-to-indirect lung injury protocol (i.e., intraamniotic LPS administration, Table 13). With a body size being $70-80 \%$ of human newborns, a gravidity length of $40 \%$, a thoracic-toabdominal relationship of $1: 1$ as in humans (compared to a relationship of 1:2-3 in rodents), and a lung:body weight ratio of 1.6 (porcine) vs. 1.8 (human), the piglet model excels also taking into account the similarities of the innate immunity, such as an $80 \%$ accordance of the hypervariable region of the Toll-like receptor 4, LPS response, and production of nitric oxide.

As we know that pathophysiologic peculiarities in ARDS of different age groups show considerable overlap in animal models (Schouten et al., 2015) as well as in human kind (Schouten et al., 2019), it is of uttermost importance to describe and to tackle the numerous facets of innate immunity in the various animal models. With age-dependent changes in lung morphology, cell integrity, and above all wide variations in severity of acute lung injury, most of the direct (e.g., lavage, MAS) or direct-to-indirect acute lung injury protocols are able to elicit at least some of these responses which may be even more pronounced and more diverse in multiple-hit models.

Direct lung injury in newborn animals aims at alveolar epithelial damage, alveolar edema, generation of hyaline membranes, disruption of the alveolar basal membrane, epithelial-to-mesenchymal transition, PMNL migration, induced macrophage activity, cytokine storm, protease and phospholipase activation, coagulation abnormalities, oxidative stress, and increased production of antioxidants. As prognostic biomarkers indicating increased mortality in human ARDS patients do not differentiate direct and indirect forms of ARDS [SP-D in serum excepted (Calfee et al., 2015)] it is important to acknowledge that existing neonatal lung injury models almost exclusively represent direct lung injury for reasons of achievement of acuity, stability of the model, and indispensable characteristics of acute lung injury involving clinical features, physiological changes, biological changes, and pathological changes (MatuteBello et al., 2008). From a practical point of view newborn models of NARDS may therefore profit more from surfactant therapy than the lungs from indirect models as demonstrated in clinical studies with children (Khemani et al., 2019) and adults (Taut et al., 2008). Finally, newborn animal models of NARDS profit from small body sizes/weights in order to evaluate specific therapy modalities, such as surfactant administration in escalating doses, antibody therapies, or modulation of major pro-inflammatory pathways, all of which are subject to $\mathrm{R}$ and $\mathrm{D}$ and may be extremely expensive. In this regard it is important to be aware of the similarities in NARDS, PARDS, and ARDS (De Luca, 2019), of the impact of the innate immunity, and of 
TABLE 11 | Meconium aspiration model.

\begin{tabular}{|c|c|c|c|c|c|c|c|c|c|c|}
\hline References & $\begin{array}{c}\text { Age } \\
\text { (days) }\end{array}$ & $\begin{array}{l}\text { Meconium } \\
(\%)\end{array}$ & $\begin{array}{l}\text { Volume } \\
(\mathrm{ml} / \mathrm{kg})\end{array}$ & $\begin{array}{l}\text { PIP/PEEP* } \\
\text { (mbar) }\end{array}$ & $\begin{array}{c}V_{\mathrm{T}}^{\#} \\
(\mathrm{ml} / \mathrm{kg})\end{array}$ & $\begin{array}{l}\text { Study } \\
\text { I. }{ }^{\$} \text { (h) }\end{array}$ & $\begin{array}{c}\mathrm{C}_{\mathrm{rs}} / \mathrm{R}_{\mathrm{rs}}^{\S} \\
(\mathrm{ml} / \mathrm{mbar} / \mathrm{kg}) \\
\left(\mathrm{mbar} / \mathrm{I}^{*} \mathrm{sec}\right)\end{array}$ & $\begin{array}{c}\text { PAP/PVR(l) })^{\mathbb{I l}} \\
(\mathrm{mmHg}) \\
(\mathrm{mmHg} / \mathrm{ml} / \mathrm{kg} / \mathrm{min} \\
\left.\text { a.o. }{ }^{\dagger}\right)\end{array}$ & Intervention & Immunologic response \\
\hline \multirow[t]{2}{*}{ Davey et al. (1993) } & $1-2$ & 20 & 3 & $13 / 3$ & $11 \pm 1$ & 48 & $\begin{array}{l}1.5 \pm 0.2 \rightarrow \\
1.6 \pm 0.4\end{array}$ & - & None & $\begin{array}{l}\text { Albumin: } 20 \pm 5 \rightarrow 105 \pm 35 \mu \mathrm{g} / \mathrm{ml} \\
\text { Protein: } 1.1 \pm 0.3 \rightarrow 2.2 \pm 0.3 \mathrm{mg} / \mathrm{ml}\end{array}$ \\
\hline & & & & & & & $\begin{array}{l}41 \pm 5 \rightarrow \\
162 \pm 27\end{array}$ & - & & \\
\hline \multirow[t]{2}{*}{ Wiswell et al. (1994) } & $1-5$ & 33 & 3 & $15 / 4 \rightarrow 23 / 5$ & - & 6 & - & - & Beractant, poractatant & Protein: $1.1 \pm 0.4$ vs. $1.1 \pm 0.2 \mathrm{mg} / \mathrm{ml}$ \\
\hline & & & & & & & - & - & & $\begin{array}{l}\text { Phospholipids: } 3.8 \pm 1.5 \text { vs. } 6.2 \pm 3.0 \\
\mu \mathrm{g} / \mathrm{ml}\end{array}$ \\
\hline \multirow[t]{3}{*}{ Holopainen et al. (1999a) } & $10-12$ & $2,6.5$ & 3 & $/ 2-3$ & $16-20$ & 6 & - & - & None & MPO: $9 \pm 1$ vs. $53 \pm 13 \mathrm{U} / \mathrm{g}$ protein \\
\hline & & & & & & & & & & $\begin{array}{l}\mathrm{PLA} \text { : } 0.02 \pm 0.01 \text { vs. } 0.16 \pm 0.03 \mathrm{U} / \mathrm{g} \\
\text { protein }\end{array}$ \\
\hline & & & & & & & & & & $\begin{array}{l}\text { AEC apoptosis: } 7 \pm 2 \text { vs. } 16 \pm 2 \\
\text { cells/mm } / \mathrm{mm}^{2}\end{array}$ \\
\hline \multirow[t]{2}{*}{ Holopainen et al. (1999b) } & $10-12$ & 6.5 & 3 & $/ 2-3$ & $16-20$ & 6 & - & - & NO 1, 10 ppm & MPO: $53 \pm 13$ vs. $57 \pm 11 \mathrm{mU} / \mathrm{mg}$ protein \\
\hline & & & & & & & - & $\begin{array}{c}11 \pm 1 \rightarrow 28 \pm 2 \\
\mathrm{mmHg} / / \mathrm{min}\end{array}$ & & $\begin{array}{l}\text { PLA } 2: 0.16 \pm 0.03 \text { vs. } 0.11 \pm 0.04 \mathrm{U} / \mathrm{g} \\
\text { AEC apoptosis: } 16 \pm 2 \text { vs. } 6 \pm 3 \\
\text { cells } / \mathrm{mm}^{2}\end{array}$ \\
\hline \multirow[t]{2}{*}{ Kuo and Chen (1999) } & $<8$ & 20 & 3 & $12 \rightarrow 29 / 4$ & - & 4 & $\begin{array}{l}1.2 \pm 0.4 \rightarrow \\
0.3 \pm 0.1\end{array}$ & $19 \pm 3 \rightarrow 31 \pm 4$ & None & $\begin{array}{l}\text { Blood endothelin-1: } 1.6 \pm 0.2 \text { vs. } \\
2.2 \pm 0.4 \mathrm{pg} / \mathrm{ml}\end{array}$ \\
\hline & & & & & & & $\begin{array}{r}23 \pm 5 \rightarrow \\
35 \pm 9\end{array}$ & $\begin{array}{r}960 \pm 290 \rightarrow \\
2,620 \pm 490\end{array}$ & & \\
\hline \multirow[t]{2}{*}{ Holopainen et al. (2001) } & $10-12$ & 6.5 & 3 & $/ 2-3$ & $16-20$ & 6 & - & $13 \pm 3 \rightarrow 26 \pm 7$ & $\begin{array}{l}\text { Dexamethasone } \\
0.5 \mathrm{mg}\end{array}$ & $\mathrm{PLA}_{2}: 0.16 \pm 0.07$ vs. $0.23 \pm 0.14 \mathrm{U} / \mathrm{I}$ \\
\hline & & & & & & & - & $\begin{array}{c}11 \pm 4 \rightarrow 29 \pm 7 \\
\mathrm{mmHg} / / \mathrm{min}\end{array}$ & & $\begin{array}{l}\text { AEC apoptosis: } 14 \pm 3 \text { vs. } 6 \pm 1 \\
\text { cells } / \mathrm{mm}^{2}\end{array}$ \\
\hline \multirow[t]{2}{*}{ Kuo and Liao (2001) } & $1-7$ & 20 & 3 & $12 \rightarrow 24 / 4$ & & 4 & - & $22 \pm 2 \rightarrow 33 \pm 4$ & & - \\
\hline & & & & & & & & $\begin{array}{l}1,210 \pm 240 \rightarrow \\
2,650 \pm 450 \\
\text { dyne } e^{*} \mathrm{~s}^{*} \mathrm{~cm}^{-5}\end{array}$ & & \\
\hline \multirow[t]{2}{*}{ Kuo (2001) } & $1-7$ & 20 & 3 & $12 \rightarrow 24 / 4$ & - & 4 & - & $22 \pm 3 \rightarrow 33 \pm 3$ & BQ-123 $8 \mathrm{mg}$ iv ${ }^{f}$ & Blood endothelin-1: no difference (?) \\
\hline & & & & & & & - & $\begin{array}{l}1,246 \pm 274 \rightarrow \\
2,591 \pm 545 \\
\text { dyne* } \mathrm{s}^{*} \mathrm{~cm}^{-5}\end{array}$ & & \\
\hline \multirow[t]{2}{*}{ Tollofsrud et al. (2001) } & $4-12$ & 11 & 3 & $18 / 3 \rightarrow 23 \pm 3$ & $10-15$ & 2 & $\begin{array}{l}1.2 \pm 0.2 \rightarrow \\
0.8 \pm 0.1\end{array}$ & $17 \pm 3 \rightarrow 26 \pm 3$ & $\mathrm{~F}_{\mathrm{i}} \mathrm{O}_{2}: 0.21$ vs. 1.0 & $\begin{array}{l}\text { Blood hypoxanthin: } 56 \pm 20 \text { vs. } 38 \pm 10 \\
\mu \mathrm{mol} / /\end{array}$ \\
\hline & & & & & & & $\begin{array}{r}73 \pm 2 \rightarrow \\
104 \pm 12\end{array}$ & $\begin{array}{c}0.02 \pm 0.02 \rightarrow \\
0.04 \pm 0.02\end{array}$ & & \\
\hline
\end{tabular}


TABLE 11 | Continued

\begin{tabular}{|c|c|c|c|c|c|c|c|c|c|c|}
\hline References & $\begin{array}{c}\text { Age } \\
\text { (days) }\end{array}$ & $\begin{array}{l}\text { Meconium } \\
(\%)\end{array}$ & $\begin{array}{l}\text { Volume } \\
(\mathrm{ml} / \mathrm{kg})\end{array}$ & $\begin{array}{l}\text { PIP/PEEP* } \\
\text { (mbar) }\end{array}$ & $\begin{array}{c}V_{T}^{\#} \\
(\mathrm{ml} / \mathrm{kg})\end{array}$ & $\begin{array}{l}\text { Study } \\
\text { I. }{ }^{\$} \text { (h) }\end{array}$ & $\begin{array}{c}\mathrm{C}_{\mathrm{rs}} / \mathrm{R}_{\mathrm{rs}}^{\S} \\
(\mathrm{ml} / \mathrm{mbar} / \mathrm{kg}) \\
\left(\mathrm{mbar} / \mathrm{I}^{*} \mathrm{sec}\right)\end{array}$ & $\begin{array}{c}\text { PAP/PVR(l) } \\
(\mathrm{mmHg}) \\
(\mathrm{mmHg} / \mathrm{ml} / \mathrm{kg} / \mathrm{min} \\
\left.\text { a.o. }{ }^{\dagger}\right)\end{array}$ & Intervention & Immunologic response \\
\hline \multirow[t]{2}{*}{ Tølløfsrud et al. (2002) } & $0-2$ & 11 & 3 & $20 / 3$ & $10-15$ & 8 & $\begin{array}{c}1.4 \pm 0.2 \rightarrow \\
0.9 \pm 0.3\end{array}$ & $23 \pm 4 \rightarrow 33 \pm 6$ & $\mathrm{~F}_{\mathrm{i}} \mathrm{O}_{2}$, albumin & Endothelin-1: $2.4 \pm 1.0$ vs. $2.1 \pm 0.7 \mathrm{ng} / \mathrm{l}$ \\
\hline & & & & & & & $\begin{array}{r}88 \pm 5 \rightarrow \\
110 \pm 40\end{array}$ & $\begin{array}{c}0.10 \pm 0.05 \rightarrow \\
0.18 \pm 0.08\end{array}$ & & \\
\hline \multirow[t]{3}{*}{ Dargaville et al. (2003) } & 14 & 20 & 4 & $15-20 / 4$ & - & 5 & $\begin{array}{c}0.9 \pm 0.1 \rightarrow \\
0.4 \pm 0.1\end{array}$ & - & $\begin{array}{l}\text { Surfactant and } \\
\text { perfluorocarbon }\end{array}$ & $\begin{array}{l}\text { Protein: } 7.1 \pm 3.2 \text { vs. } 4.7 \pm 1.9 \text { vs. } \\
8.2 \pm 3.8 \mathrm{mg} / \mathrm{ml}\end{array}$ \\
\hline & & & & & & & $\begin{array}{r}75 \pm 3 \rightarrow \\
122 \pm 8\end{array}$ & - & & $\begin{array}{l}\text { Albumin: } 3.3 \pm 2.3 \text { vs. } 1.9 \pm 1.1 \text { vs. } \\
4.1 \pm 2.9 \mathrm{mg} / \mathrm{ml}\end{array}$ \\
\hline & & & & & & & & & & $\begin{array}{l}\text { DPPC: } 0.6 \pm 0.5 \text { vs. } 1.0 \pm 0.3 \text { vs. } \\
1.1 \pm 0.5 \mathrm{mg} / \mathrm{ml}\end{array}$ \\
\hline \multirow[t]{4}{*}{ Hilgendorff et al. (2003) } & $1-11$ & 20 & 5 & $15 \rightarrow 25 / 2 \rightarrow$ & $?$ & 5.5 & - & - & rSP-C surfactant & Tissue IL-1 $1 \beta: 1.0 \pm 0.3$ vs. $0.2 \pm 0.3 \mathrm{aU}^{\ddagger}$ \\
\hline & & & & & & & & & & Tissue IL-6: $1.0 \pm 0.3$ vs. $2.1 \pm 0.4 \mathrm{aU}$ \\
\hline & & & & & & & & & & $\begin{array}{l}\text { Tissue IL-8: } 1.0 \pm 0.2 \text { vs. } 0.4 \pm 0.2 \mathrm{aU} \\
\text { Tissue TGF- } \beta: 1.0 \pm 0.4 \text { vs. } 1.0 \pm 0.2 \mathrm{aU}\end{array}$ \\
\hline & & & & & & & & & & Tissue IL-10: $1.0 \pm 0.6$ vs. $3.5 \pm 0.5 \mathrm{aU}$ \\
\hline \multirow[t]{4}{*}{ Korhonen et al. (2003) } & $1-3$ & 6.5 & 1.5 & $20 / 4$ & - & 12 & - & - & Surfactant & $\begin{array}{l}\text { MPO: } 0.5 \pm 0.2 \text { vs. } 0.8 \pm 0.2 \mathrm{U} / \mathrm{mg} \\
\text { protein }\end{array}$ \\
\hline & & & & & & & & & & Protein: $1.4 \pm 0.7$ vs. $2.6 \pm 0.4$ mg/ml \\
\hline & & & & & & & & & & TNF- $\alpha: 121 \pm 20$ vs. $157 \pm 33 \mathrm{pg} / \mathrm{ml}$ \\
\hline & & & & & & & & & & $\mathrm{PLA}_{2}: 8 \pm 6$ vs. $401 \pm 91 \mathrm{U} / \mathrm{l}$ \\
\hline Castellheim et al. (2004) & $0-2$ & 13.5 & 4 & - & - & 5 & - & - & None & Blood C5b-9: 0.3 vs. $1.5-2.4 \mathrm{U} / \mathrm{ml}$ \\
\hline \multirow[t]{3}{*}{ Korhonen et al. (2004) } & $0-2$ & 6.5 & 1.5 & $20 / 4$ & - & 12 & - & - & Pentoxifylline $20 \mathrm{mg} / \mathrm{kg}$ & TNF- $\alpha: 42 \pm 22$ vs. $17 \pm 5 \mathrm{pg} / \mathrm{ml}$ \\
\hline & & & & & & & & & iv & Protein $1.1 \pm 0.3$ vs. $0.6 \pm 0.2 \mathrm{mg} / \mathrm{ml}$ \\
\hline & & & & & & & & & & Tissue MPO: $1.6 \pm 1.0$ vs. $1.5 \pm 0.2$ \\
\hline \multirow[t]{3}{*}{ Lindenskov et al. (2004) } & $0-2$ & 13.5 & 5 & 15 & $13-15$ & 5 & $2.2 \pm 0.1 \rightarrow$ & - & None & Blood C5b-9: +82 $\pm 34 \%$ \\
\hline & & & & & & & $1.2 \pm 0.1$ & & & Blood IL-1 $\beta: 25 \pm 48 \rightarrow 112 \pm 50 \mathrm{pg} / \mathrm{ml}$ \\
\hline & & & & & & & & & & $\begin{array}{l}\text { Blood TNF- } \alpha: 55 \pm 28 \rightarrow 128 \pm 15 \% \\
\text { increase }\end{array}$ \\
\hline \multirow[t]{2}{*}{$\begin{array}{l}\text { Shekerdemian et al. } \\
\text { (2004) }\end{array}$} & $?$ & 20 & 3 & $?$ & - & 6 & - & $18 \pm 1 \rightarrow 24 \pm 1$ & $\mathrm{BQ}-1231 \mathrm{mg} / \mathrm{kg}$ iv $f$ & $\begin{array}{l}\text { Blood endothelin-1: } 2.2 \pm 0.4 \text { vs. } \\
2.9 \pm 0.3 \mathrm{pg} / \mathrm{ml}\end{array}$ \\
\hline & & & & & & & - & $\begin{array}{c}65 \pm 5 \rightarrow 106 \pm 10 \\
\mathrm{mU} / \mathrm{kg}\end{array}$ & & \\
\hline
\end{tabular}




\section{TABLE 11 | Continued}

\begin{tabular}{|c|c|c|c|c|c|c|c|c|c|c|}
\hline References & $\begin{array}{c}\text { Age } \\
\text { (days) }\end{array}$ & $\begin{array}{l}\text { Meconium } \\
(\%)\end{array}$ & $\begin{array}{l}\text { Volume } \\
(\mathrm{ml} / \mathrm{kg})\end{array}$ & $\begin{array}{l}\text { PIP/PEEP* } \\
\text { (mbar) }\end{array}$ & $\begin{array}{c}V_{T}^{\#} \\
(\mathrm{ml} / \mathrm{kg})\end{array}$ & $\begin{array}{l}\text { Study } \\
\text { I. }{ }^{\$}(\mathrm{~h})\end{array}$ & $\begin{array}{c}\mathrm{C}_{\mathrm{rs}} / \mathrm{R}_{\mathrm{rs}}^{\S} \\
(\mathrm{ml} / \mathrm{mbar} / \mathrm{kg}) \\
\left(\mathrm{mbar} / /^{*} \mathrm{sec}\right)\end{array}$ & $\begin{array}{c}\text { PAP/PVR(l) } \\
(\mathrm{mmHg}) \\
(\mathrm{mmHg} / \mathrm{ml} / \mathrm{kg} / \mathrm{min} \\
\left.\text { a.o. }{ }^{\dagger}\right)\end{array}$ & Intervention & Immunologic response \\
\hline Tølløfsrud et al. (2004) & $0-2$ & 11 & 3 & - & - & 8 & - & - & Albumin it & IL-8: $17 \pm 13$ vs. $94 \pm 57 \mathrm{pg} / \mathrm{ml}$ \\
\hline van Kaam et al. (2004a) & $35 \pm 15 h$ & 14 & 10 & $\begin{array}{l}8-10 / 2 \rightarrow \\
15-22 / 4\end{array}$ & - & 6 & - & - & CV vs. HFO ${ }^{\pi}$ & MPO: $0.7 \pm 0.1$ vs. $0.5 \pm 0.1 \mathrm{U} / \mathrm{ml}$ \\
\hline Castellheim et al. (2005) & $0-2$ & 13.5 & 4 & $<45 / ?$ & $12 \pm 4$ & 7 & $\begin{array}{l}2.2 \pm 0.4 \rightarrow \\
1.0 \pm 0.3\end{array}$ & - & None & $\begin{array}{l}\text { Blood C5b-9: } 0.2 \pm 0.1 \text { vs. } 3.8 \pm 1.8 \mathrm{aU} \\
\text { Blood IL-6: } 40 \pm 60 \text { vs. } 460 \pm 390 \mathrm{pg} / \mathrm{ml} \\
\text { Blood IL-8: } 20 \pm 4 \text { vs. } 26 \pm 6 \mathrm{pg} / \mathrm{ml} \\
\text { Blood CD11/18: not different (?) }\end{array}$ \\
\hline Holopainen et al. (2005) & $10-12$ & 6.5 & 3 & $/ 2-3$ & $16-20$ & 6 & - & $\begin{array}{c}- \\
(+165 \%)\end{array}$ & ivlg $0.8 \mathrm{~g} / \mathrm{kg}^{\Delta}$ & $\begin{array}{l}\text { MPO: } 11 \pm 3 \text { vs. } 215 \pm 58 \mathrm{mU} / \mathrm{g} \text { protein } \\
\text { PLA }_{2}: 0.15 \pm 0.07 \text { vs. } 0.10 \pm 0.03 \mathrm{U} / \mathrm{g}\end{array}$ \\
\hline Lindenskov et al. (2005) & $0-2$ & 13.5 & 4 & $<45 / ?$ & - & 8 & $\begin{array}{c}-46-60 \% \\
-\end{array}$ & $\begin{array}{c}21 \pm 2 \rightarrow 32 \pm 10 \\
-\end{array}$ & Albumin & $\begin{array}{l}\text { IL-8: } 9.5 \pm 1.6 \text { vs. } 9.6 \pm 0.4 \mathrm{ng} / \mathrm{ml} \\
\text { Protein } 3.5 \pm 0.3 \text { vs. } 3.6 \pm 0.5 \mathrm{mg} / \mathrm{ml}\end{array}$ \\
\hline Hilgendorff et al. (2006) & $1-11$ & 20 & 5 & 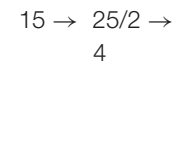 & - & 5.5 & $\begin{aligned} 2.2 & \pm 0.2 \rightarrow \\
0.7 & \pm 0.1\end{aligned}$ & - & rSP-C surfactant & $\begin{array}{l}\text { Tissue SP-B: } 0.1(0.1-0.4) \text { vs. } 0.6 \\
(0.1-1.0) 2^{\wedge} \Delta \Delta \mathrm{ct} \\
\text { Tissue SP-C: } 0.5(0.3-0.5) \text { vs. } 0.5 \\
(0.1-0.8) 2^{\wedge} \Delta \Delta \mathrm{ct}\end{array}$ \\
\hline Jeng et al. (2006) & $<14$ & 25 & $3-5$ & $10-13 / 3$ & 10 & 4 & $\begin{array}{r}1.1 \pm 0.2 \rightarrow \\
0.4 \pm 0.1\end{array}$ & - & $\begin{array}{l}\text { Surfactant and liquid } \\
\text { ventilation }\end{array}$ & $\begin{array}{l}\text { Blood IL- } 1 \beta: 2.3 \pm 0.3 \text { vs. } 0.1 \pm 0.02 \\
\mathrm{ng} / \mathrm{ml} \\
\text { Blood IL-6: } 1.6 \pm 0.4 \text { vs. } 0.1 \pm 0.03 \mathrm{ng} / \mathrm{ml}\end{array}$ \\
\hline Angert et al. (2007) & $1-3$ & 20 & 3 & $/ 3$ & - & 24 & - & - & rhCC10 5 mg/kg it屯 & $\begin{array}{l}\text { IL- } 8: 4.8 \pm 1.9 \text { vs. } 5.5 \pm 2.8 \mathrm{ng} / \mathrm{mg} \\
\text { protein } / \mathrm{ml} \\
\text { TNF- } \alpha: 1.3 \pm 0.6 \text { vs. } 0.5 \pm 0.3 \mathrm{ng} / \mathrm{mg} \\
\text { protein } / \mathrm{ml}\end{array}$ \\
\hline Salvesen et al. (2008) & $0-2$ & 13.5 & 4 & $18-20 / 4$ & $8-14$ & 6 & $\begin{array}{c}2.1 \pm 0.2 \rightarrow \\
0.9 \pm 0.3 \\
59 \pm 5 \rightarrow \\
69 \pm 24\end{array}$ & $\begin{array}{l}- \\
-\end{array}$ & Albumin $0.6 \mathrm{~g} / \mathrm{kg}$ it & $\begin{array}{l}\text { Blood sC5b-9: } 0.2 \pm 0.7 \text { vs. } 0.9 \pm 1.6 \\
\text { aU/ml } \\
\text { Blood TNF- } \alpha: 82 \pm 19 \text { vs. } 62 \pm 7 \mathrm{pg} / \mathrm{ml} \\
\text { Blood IL- } 1 \beta: 29 \pm 75 \text { vs. } 83 \pm 44 \text { pg/ml } \\
\text { Blood IL-6: } 32 \pm 95 \text { vs. } 50 \pm 87 \text { pg/ml }\end{array}$ \\
\hline Saugstad et al. (2008) & $2-5$ & ? & $3-4$ & ? & $10-15$ & 8 & - & - & Albumin it & IL-8: 93 vs. 18 pg/ml \\
\hline
\end{tabular}


TABLE 11 | Continued

\begin{tabular}{|c|c|c|c|c|c|c|c|c|c|c|}
\hline References & $\begin{array}{l}\text { Age } \\
\text { (days) }\end{array}$ & $\begin{array}{l}\text { Meconium } \\
\text { (\%) }\end{array}$ & $\begin{array}{l}\text { Volume } \\
(\mathrm{ml} / \mathrm{kg})\end{array}$ & $\begin{array}{l}\text { PIP/PEEP* } \\
\text { (mbar) }\end{array}$ & $\begin{array}{c}V_{T}^{\#} \\
(\mathrm{ml} / \mathrm{kg})\end{array}$ & $\begin{array}{l}\text { Study } \\
\text { 1. }{ }^{\$} \text { (h) }\end{array}$ & $\begin{array}{c}\mathrm{C}_{\mathrm{rs}} / \mathbf{R}_{\mathrm{rs}}^{\S} \\
(\mathrm{ml} / \mathrm{mbar} / \mathrm{kg}) \\
\left(\mathrm{mbar} / /^{*} \mathrm{sec}\right)\end{array}$ & $\begin{array}{c}\text { PAP/PVR(l) } \\
(\mathrm{mmHg}) \\
(\mathrm{mmHg} / \mathrm{ml} / \mathrm{kg} / \mathrm{min} \\
\left.\text { a.o. }{ }^{\dagger}\right)\end{array}$ & Intervention & Immunologic response \\
\hline Wang et al. (2010) & $7-14$ & 20 & $3-5$ & $17 \rightarrow 27 / 5$ & 10 & 4 & $\begin{array}{c}1.4 \pm 0.2 \rightarrow \\
0.6 \pm 0.1\end{array}$ & - & Surfactant & $\begin{array}{l}\text { IL- } 1 \beta: 265 \pm 61 \text { vs. } 65 \pm 18 \mathrm{ng} / \mathrm{ml} \\
\text { IL-6: } 0.6 \pm 0.4 \text { vs. } 0.1 \pm 0.1 \mu \mathrm{g} / \mathrm{ml} \\
\text { TNF- } \alpha: 0.4 \pm 0.1 \text { vs. } 0.4 \pm 0.1 \mu \mathrm{g} / \mathrm{ml} \\
\text { AEC apoptosis: } 22 \pm 6 \text { vs. } 8 \pm 4 \text { per } \\
\text { power field }\end{array}$ \\
\hline Salvesen et al. (2014) & $0-2$ & 10 & 4.5 & $18-20 / 5$ & $6-12$ & 6 & $\begin{array}{c}2.0 \pm 0.2 \rightarrow \\
0.8 \pm 0.2\end{array}$ & - & $\begin{array}{l}\text { Poractant alpha and } \\
\text { CHF5633 }\end{array}$ & $\begin{array}{l}\text { Blood lipid peroxidation: } 1.5 \pm 0.4 \text { vs. } \\
0.4 \pm 0 \text { nmol/mg } \\
\text { Blood sC5b-9: } 0.8 \pm 0.4 \text { vs. } 1.1 \pm 0.5 \\
\text { aU/ml } \\
\text { Blood TAT : } 50 \pm 29 \text { vs. } 145 \pm 81 \mu \mathrm{g} / \mathrm{ml} \\
\text { Blood PAl- }{ }^{\natural}: 145 \pm 42 \text { vs. } 72 \pm 25 \mathrm{ng} / \mathrm{ml} \\
\text { Blood TNF- } \alpha: 90 \pm 21 \text { vs. } 150 \pm 25 \mathrm{pg} / \mathrm{ml} \\
\text { Blood IL-6: } 0.2 \pm 0.06 \text { vs. } 0.6 \pm 0.3 \mathrm{ng} / \mathrm{ml} \\
\text { Blood IL-1 } 1 \beta: 0.18 \pm 0.04 \text { vs. } 0.11 \pm 0.04 \\
\text { ng/ml }\end{array}$ \\
\hline Lin et al. (2016) & $<14$ & 25 & $6-7$ & $11 \rightarrow 20 / 5$ & 8 & 6 & $\begin{array}{c}1.3 \pm 0.1 \rightarrow \\
0.6 \pm 0.1\end{array}$ & $\begin{array}{l}- \\
-\end{array}$ & $\begin{array}{l}\text { Surfactant and } \\
\text { budenoside }\end{array}$ & $\begin{array}{l}\text { IL-1ß: } 2.1(2.0-3.1) \text { vs. } 0.8(0.3-1.3) \mathrm{ng} / \mathrm{ml} \\
\text { IL-6: } 2.7(2.4-2.8) \text { vs. } 1.3(2.1-0.7) \mathrm{ng} / \mathrm{ml} \\
\text { IL-8: } 2.8(2.1-4.6) \text { vs. } 1.7(0.4-3.3) \mathrm{ng} / \mathrm{ml}\end{array}$ \\
\hline Lin et al. (2017) & $4-12$ & 25 & 6 & $15 / 5 \rightarrow 23 \pm 1$ & - & 8 & $\begin{array}{c}0.9 \pm 0.1 \rightarrow \\
0.6 \pm 0.01\end{array}$ & - & Dexa, budenoside iv & Tissue lung injury score: $\downarrow$ \\
\hline Thomas et al. (2018) & 2 & 9.9 & 5.5 & $/ 5$ & - & 5 & - & - & Anti-CD14, anti-C5a & $\begin{array}{l}\text { Blood IL-1 } 1 \beta: 240 \pm 45 \text { vs. } 172 \pm 52 \mathrm{pg} / \mathrm{ml} \\
\text { Blood IL-6: } 154 \pm 38 \text { vs. } 181 \pm 34 \mathrm{pg} / \mathrm{ml} \\
\text { MPO: } 856 \pm 35 \text { vs. } 265 \pm 30 \mathrm{ng} / \mathrm{ml}\end{array}$ \\
\hline
\end{tabular}

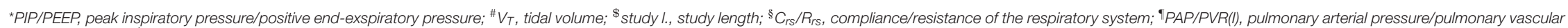

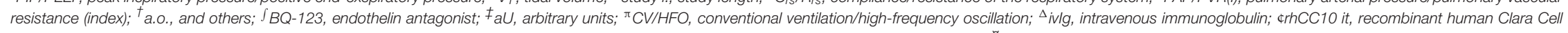
protein 10, intratracheally administered; $\sim$ CHF5633, synthetic surfactant containing SP-B/C, DPPC, POPG; TAT, thrombin antithrombin complex; ${ }^{\circledR}$ PAl-1, plasminogen activator inhibitor-1.

PIP/PEEP, $C_{r s} / R_{r s}$, PAP/PVR(I), immunologic response: arrow $\rightarrow$ ) delineates changes by the lung injury protocol (i.e., meconium instillation into the airways); vs. delineates differences secondary to a specific intervention (first place control group, second place intervention group data).

Immunologic response parameters are from broncho-alveolar lavage fluid (BALF) unless specified otherwise. 
TABLE 12 | Lavage model.

\begin{tabular}{|c|c|c|c|c|c|c|c|c|c|c|c|}
\hline References & $\begin{array}{l}\text { Age } \\
\text { (days) }\end{array}$ & $\begin{array}{l}\text { Lavages } \\
\text { (n) }\end{array}$ & $\begin{array}{l}\text { Volume } \\
(\mathrm{ml} / \mathrm{kg})\end{array}$ & $\begin{array}{l}\text { PIP/PEEP* } \\
\text { (mbar) }\end{array}$ & $\begin{array}{c}V_{T}^{\#} \\
(\mathrm{ml} / \mathrm{kg})\end{array}$ & $\begin{array}{l}\text { study I. } \\
\text { (h) }\end{array}$ & $\begin{array}{c}\mathrm{C}_{\mathrm{rs}}^{\S} \\
(\mathrm{ml} / \mathrm{mbar} / \mathrm{kg})\end{array}$ & $\begin{array}{c}\mathbf{R}_{\mathrm{rs}}^{\mathbb{I}} \\
\left(\mathrm{mbar} / \mathrm{l}^{*} \mathrm{sec}\right)\end{array}$ & $\mathrm{FRC}^{\dagger}(\mathrm{ml} / \mathrm{kg})$ & Intervention & Immunologic response \\
\hline Sood et al. (1996a) & $4-9$ & $?$ & 35 & $17 \rightarrow 29 / 6$ & - & 1.5 & $\begin{array}{l}1.3 \pm 0.1 \rightarrow \\
0.5 \pm 0.1\end{array}$ & $\begin{array}{c}32 \pm 3 \rightarrow \\
58 \pm 3\end{array}$ & $\begin{array}{c}29 \pm 1 \rightarrow \\
12 \pm 2\end{array}$ & $\begin{array}{l}\text { Beractant, DPPC, } \\
\text { and } K L 4^{\ddagger}\end{array}$ & $\begin{array}{l}\text { Protein: } 347 \pm 142 \text { vs. } 56 \pm 13 \mathrm{mg} / \mathrm{dll} \\
\text { (KL4) histopathology scores: no difference }\end{array}$ \\
\hline $\begin{array}{l}\text { Abubakar et al. } \\
\text { (1998) (double-hit: } \\
\text { lavage and } \\
\text { overventilation) }\end{array}$ & $<3$ & $?$ & 35 & $\begin{aligned} 15 & \rightarrow 40 \\
\rightarrow & ? / 3 \rightarrow 2 \\
& \rightarrow 4\end{aligned}$ & $10-13$ & 24 & - & - & - & Heparin, ATIII & $\begin{array}{l}\text { ATIII: } 49 \pm 8 \text { vs. } 57 \pm 10 \mu \mathrm{g} / \mathrm{ml} \\
125 \text {-fibrinogen uptake: } 19 \pm 10 \text { vs. } \\
10 \pm 9 \% \\
\text { lung injury score: } 1.99 \pm 0.71 \text { vs. } \\
1.55 \pm 0.63\end{array}$ \\
\hline $\begin{array}{l}\text { Balaraman et al. } \\
\text { (1998) }\end{array}$ & $4-8$ & $\begin{array}{c}13 \pm 1+ \\
4\end{array}$ & 35 & $? \rightarrow 32 / 6$ & - & 4 & $? \rightarrow 0.7 \pm 0.1$ & $?$ & $?$ & (un)diluted DPPC & $\begin{array}{l}\text { Protein: } 25 \pm 6 \text { vs. } 15 \pm 9 \mathrm{mg} / \mathrm{dll} \text { (undil. vs. } \\
\text { dil.) }\end{array}$ \\
\hline Jeng et al. (2002) & $1-14$ & $?$ & 30 & 15 & 15 & 3 & $\begin{array}{l}1.7 \pm 0.2 \rightarrow \\
0.8 \pm 0.1\end{array}$ & - & - & $\mathrm{FC}-77^{\pi}$ & $\begin{array}{l}\text { Alveolar inflammation score: } 1.8 \pm 04 \text { vs. } \\
0.6 \pm 0.3 \\
\mathrm{AEC}^{\Delta} \text { necrosis score: } 3.1 \pm 0.5 \text { vs. } \\
1.4 \pm 0.3\end{array}$ \\
\hline Merz et al. (2002) & $1-3$ & ? & 30 & $\begin{aligned} 16 & \rightarrow 20 / 2 \\
& \rightarrow 4\end{aligned}$ & $?$ & 24 & - & - & - & $\begin{array}{l}\text { Surfactant, HFOV } \\
\text { and liquid } \\
\text { ventilation }\end{array}$ & $\begin{array}{l}\mathrm{LTB}_{4}: 1.5 \pm 0.3 \text { vs. } 1.1 \pm 0.2 \mathrm{ng} / \mathrm{ml} \\
\text { IL-6: } 1.2 \pm 0.3 \text { vs. } 1.6 \pm 0.9 \mathrm{ng} / \mathrm{ml} \\
\text { TNF- } \alpha: 1.3 \pm 0.4 \text { vs. } 1.0 \pm 0.3 \mathrm{ng} / \mathrm{ml}\end{array}$ \\
\hline $\begin{array}{l}\text { von der Hardt } \\
\text { et al. (2002) }\end{array}$ & $?(4 \mathrm{~kg})$ & ? & 30 & $\begin{aligned} 20 & \rightarrow 32 / 4 \\
& \rightarrow 8\end{aligned}$ & - & 6 & - & - & - & FC-77 & $\begin{array}{l}\text { Tissue IL-1 } 1 \beta: 15 \pm 4 \text { vs. } 1.4 \pm 0.4 \mathrm{rUq} \\
\text { Tissue IL-6: } 1.0 \pm 0.2 \text { vs. } 0.4 \pm 0.2 \mathrm{rU} \\
\text { Tissue IL-8: } 2.4 \pm 0.6 \text { vs. } 0.7 \pm 0.3 \mathrm{rU} \\
\text { Tissue TGF- } \beta: 1.7 \pm 0.2 \text { vs. } 1.2 \pm 0.1 \mathrm{rU}\end{array}$ \\
\hline $\begin{array}{l}\text { van Kaam et al. } \\
\text { (2003b) }\end{array}$ & $0-2$ & $?$ & 50 & $\begin{array}{l}10-12 \rightarrow \\
25 / 2 \rightarrow 5 \rightarrow \\
\quad 10\end{array}$ & - & 5 & - & - & - & OLC?-ventilation & $\begin{array}{l}\text { Cells: } 0.8 \pm 0.5 \text { vs. } 0.4 \pm 0.2 \times 10^{6} / \mathrm{ml} \\
\text { IL-8: not different } \\
\text { TNF- } \alpha \text { : not different } \\
\text { Thrombin activity: not different }\end{array}$ \\
\hline $\begin{array}{l}\text { van Kaam et al. } \\
\text { (2003a) }\end{array}$ & $0-2$ & ? & 50 & $\begin{array}{l}9-12 \rightarrow 25 / 2 \\
\rightarrow 5 \rightarrow 15\end{array}$ & - & 5 & - & - & - & OLC-ventilation & Protein: $0.7 \pm 0.2$ vs. $1.0 \pm 0.1$ \\
\hline $\begin{array}{l}\text { van Kaam et al. } \\
\text { (2004a) }\end{array}$ & $?$ & $?$ & 50 & $25 / 4-5 \rightarrow 10$ & 7 & 5 & - & - & $\begin{array}{c}\text { TLC }: \\
57 \pm 20 \rightarrow\end{array}$ & $\begin{array}{l}\text { OLC-ventilation on } \\
\text { GBS it }\urcorner\end{array}$ & $\begin{array}{l}\text { Bacterial infiltration score: } 11 \pm 1 \text { vs. } 4 \pm 1 \\
\text { Cellular infiltration score: } 11 \pm 1 \text { vs. } 6 \pm 1\end{array}$ \\
\hline $\begin{array}{l}\text { van Kaam et al. } \\
\text { (2004b) }\end{array}$ & $0-2$ & $15 \pm 5$ & 50 & $8-10 / 2 \rightarrow 10$ & - & 5 & - & - & $22 \pm 6$ & $\begin{array}{l}\text { HL10 surfactant } \\
\text { and } \\
\text { OLC-ventilation }\end{array}$ & $\begin{array}{l}\text { Protein: } 0.8 \pm 0.1 \text { vs. } 0.3 \pm 0.1 \mathrm{mg} / \mathrm{ml} \\
\text { SA/LA-ratio : } 1.6 \pm 0.4 \text { vs. } 0.2 \pm 0.1 \\
\text { IL-8: } 15 \pm 7 \text { vs. } 41 \pm 20 \mathrm{pg} / \mathrm{ml} \\
\text { Cells: } 8 \pm 5 \text { vs. } 1 \pm 1 \times 10^{6} / \mathrm{ml}\end{array}$ \\
\hline
\end{tabular}


TABLE 12 | Continued

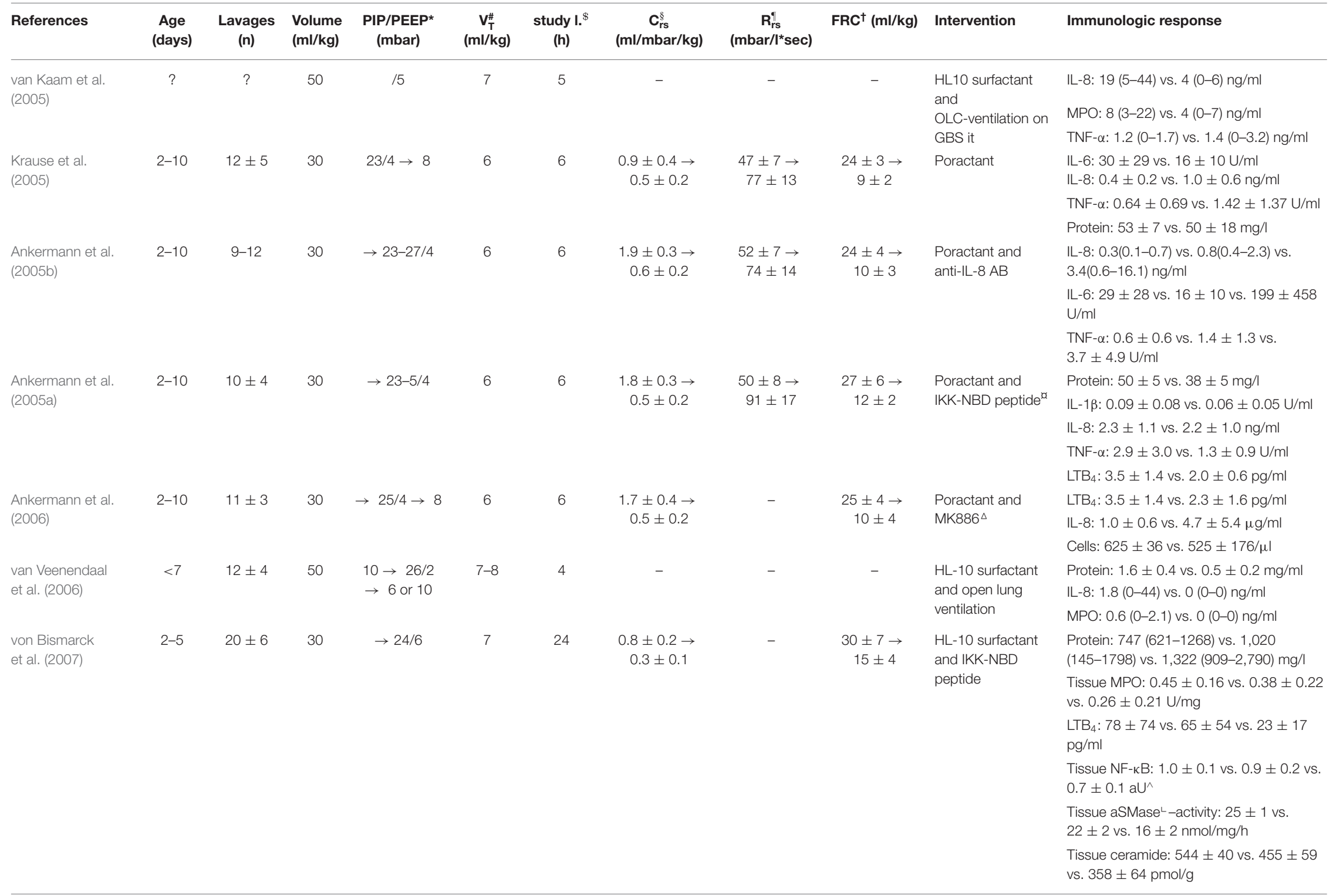


TABLE 12 | Continued

\begin{tabular}{|c|c|c|c|c|c|c|c|c|c|c|c|}
\hline References & $\begin{array}{c}\text { Age } \\
\text { (days) }\end{array}$ & $\begin{array}{l}\text { Lavages } \\
\text { (n) }\end{array}$ & $\begin{array}{l}\text { Volume } \\
(\mathrm{ml} / \mathrm{kg})\end{array}$ & $\begin{array}{l}\text { PIP/PEEP* } \\
\text { (mbar) }\end{array}$ & $\begin{array}{c}V_{T}^{\#} \\
(\mathrm{ml} / \mathrm{kg})\end{array}$ & $\begin{array}{l}\text { study I. } \\
\text { (h) }\end{array}$ & $\begin{array}{c}\mathrm{C}_{\mathrm{rs}}^{\S} \\
(\mathrm{ml} / \mathrm{mbar} / \mathrm{kg})\end{array}$ & $\begin{array}{c}\mathbf{R}_{\mathrm{rs}}^{\mathbb{I I}} \\
\left(\mathrm{mbar} / \mathrm{l}^{*} \mathrm{sec}\right)\end{array}$ & $\mathrm{FRC}^{\dagger}(\mathrm{ml} / \mathrm{kg})$ & Intervention & Immunologic response \\
\hline \multirow[t]{5}{*}{$\begin{array}{l}\text { von Bismarck } \\
\text { et al. (2008) }\end{array}$} & $2-5$ & $21 \pm 8$ & 30 & $\rightarrow 25 / 6$ & 7 & 24 & $\begin{array}{l}1.0 \pm 0.4 \rightarrow \\
0.25 \pm 0.01\end{array}$ & - & $\begin{array}{r}34 \pm 4 \rightarrow \\
23 \pm 12\end{array}$ & $\begin{array}{l}\mathrm{HL}-10 \text { surfactant } \\
\text { and imipramine }\end{array}$ & $\begin{array}{l}\text { Tissue aSMase-activity: } 27 \pm 2 \text { vs. } 20 \pm 2 \\
\text { vs. } 17 \pm 1 \mathrm{nmol} / \mathrm{mg} / \mathrm{h}\end{array}$ \\
\hline & & & & & & & & & & $5 \mathrm{mg}$ it & $\begin{array}{l}\text { Tissue ceramide: } 578 \pm 27 \text { vs. } 464 \pm 43 \\
\text { vs. } 494 \pm 38 \mathrm{pmol} / \mathrm{g}\end{array}$ \\
\hline & & & & & & & & & & & $\begin{array}{l}\text { Tissue NF-kB: } 1.0 \pm 0.4 \text { vs. } 0.5 \pm 0.1 \text { vs. } \\
0.7 \pm 0.2 \mathrm{aU}\end{array}$ \\
\hline & & & & & & & & & & & $\begin{array}{l}\mathrm{LTB}_{4}: 95 \pm 72 \text { vs. } 54 \pm 22 \text { vs. } 32 \pm 13 \\
\mathrm{pg} / \mathrm{ml}\end{array}$ \\
\hline & & & & & & & & & & & $\begin{array}{l}\text { IL-8: } 455 \pm 320 \text { vs. } 125 \pm 134 \text { vs. } \\
56 \pm 40 \mathrm{pg} / \mathrm{ml}\end{array}$ \\
\hline \multirow[t]{3}{*}{ Chada et al. (2008) } & $9-12$ & - & 30 & $\begin{aligned} 20 & \rightarrow 26 / 4 \\
& \rightarrow 6\end{aligned}$ & 7 & 12 & $\begin{array}{r}1.4 \pm 0.1 \rightarrow \\
0.3 \pm 0.05\end{array}$ & - & - & $\begin{array}{l}\text { Anakinra } 100 \mathrm{mg} \\
\text { aerosol vs. iv }\end{array}$ & $\begin{array}{l}\text { Lung injury score: } 14 \pm 3 \text { vs. } 12 \pm 4 \text { vs. } \\
10 \pm 4\end{array}$ \\
\hline & & & & & & & & & & & $\begin{array}{l}\text { Tissue IL- } 1 \beta: 4.9 \pm 2.4 \text { vs. } 0.9 \pm 0.3 \text { vs. } \\
1.9 \pm 0.6 \mathrm{rU}\end{array}$ \\
\hline & & & & & & & & & & & $\begin{array}{l}\text { Tissue IL-8: } 5.0 \pm 1.6 \text { vs. } 1.3 \pm 0.4 \text { vs. } \\
2.2 \pm 0.5 \mathrm{rU}\end{array}$ \\
\hline \multirow[t]{3}{*}{$\begin{array}{l}\text { von Bismarck } \\
\text { et al. (2009) }\end{array}$} & $2-5$ & $21 \pm 2$ & 30 & $\rightarrow 25 / 6$ & 7 & 24 & $\begin{array}{c}0.90 \pm 0.15 \rightarrow \\
0.33 \pm 0.04\end{array}$ & - & $\begin{array}{c}33 \pm 8 \rightarrow \\
16 \pm 2\end{array}$ & $\begin{array}{l}\mathrm{HL}-10 \text { surfactant, } \\
\text { dexamethasone, }\end{array}$ & $\begin{array}{l}\text { IL-8: } 2,093 \pm 583 \text { vs. } 491 \pm 144 \text { vs. } \\
351 \pm 117 \mathrm{pg} / \mathrm{ml}\end{array}$ \\
\hline & & & & & & & & & & IKK-NBD peptide & $\begin{array}{l}\text { LTB }_{4}: 78 \pm 31 \text { vs. } 71 \pm 11 \text { vs. } 23 \pm 7 \\
\mathrm{pg} / \mathrm{ml}\end{array}$ \\
\hline & & & & & & & & & & & $\begin{array}{l}\text { NF-кB activity: } 100 \pm 4 \text { vs. } 55 \pm 3 \text { vs. } \\
32 \pm 5 \%\end{array}$ \\
\hline \multirow[t]{2}{*}{ Yang et al. (2010) } & $<14$ & - & 10 & 15 & 10 & 4 & $\begin{array}{c}1.07 \pm 0.17 \rightarrow \\
0.51 \pm 0.05\end{array}$ & - & - & $\begin{array}{l}\text { Beractant and } \\
\text { budenoside }\end{array}$ & $\begin{array}{l}\text { AEC necrosis score: } 4 \text { (4) vs. } 2.5 \text { (2-3) vs. } \\
2.5(2-3)\end{array}$ \\
\hline & & & & & & & & & & & Lung injury score: 27.5 vs. 15 vs. 14 \\
\hline \multirow{8}{*}{$\begin{array}{l}\text { Preuß et al. } \\
\text { (2012b) (triple-hit: } \\
\text { lavage } \\
\text { overventilation } \\
\text { LPS) }\end{array}$} & $3-6$ & $15 \pm 2$ & 30 & 16 & 7 & 72 & $\begin{array}{c}1.3 \pm 0.2 \rightarrow \\
0.5 \pm 0.2\end{array}$ & $\begin{array}{l}51 \pm 11 \rightarrow \\
99 \pm 40\end{array}$ & - & $\begin{array}{l}\text { Poractant alfa and } \\
\text { IP3 } \diamond\end{array}$ & $\begin{array}{l}\text { Tissue aSMase activity: } 2.6 \pm 0.3 \text { vs. } \\
1.9 \pm 0.2 \text { vs. } 1.6 \pm 0.2 \mathrm{nmol} / \mathrm{g} / \mathrm{h}\end{array}$ \\
\hline & & & & & & & & & & & $\begin{array}{l}\text { Tissue ceramide: } 2.4 \pm 0.4 \text { vs. } 2.1 \pm 0.3 \\
\text { vs. } 1.6 \pm 0.4 \mathrm{nmol} / \mathrm{mg}\end{array}$ \\
\hline & & & & & & & & & & & $\begin{array}{l}\text { Tissue caspase- } 8: 100 \text { vs. } 76 \pm 8 \text { vs. } \\
60 \pm 14 \%\end{array}$ \\
\hline & & & & & & & & & & & $\begin{array}{l}\text { AEC apoptosis: } 15 \pm 2 \text { vs. } 14 \pm 2 \text { vs. } \\
7 \pm 2 \%\end{array}$ \\
\hline & & & & & & & & & & & $\begin{array}{l}\text { Tissue amphiregulin: } 1.0 \pm 1.6 \text { vs. } \\
1.5 \pm 2.1 \text { vs. } 0.1 \pm 0.1 \mathrm{rU}\end{array}$ \\
\hline & & & & & & & & & & & $\begin{array}{l}\text { Tissue TGF }-\beta 1: 1.0 \pm 0.8 \text { vs. } 0.9 \pm 0.6 \text { vs. } \\
0.02 \pm 0.01 \mathrm{rU}\end{array}$ \\
\hline & & & & & & & & & & & $\begin{array}{l}\text { Tissue IL-6: } 1.0 \pm 0.5 \text { vs. } 2.0 \pm 1.3 \text { vs. } \\
0.05 \pm 0.01 \mathrm{rU}\end{array}$ \\
\hline & & & & & & & & & & & $\begin{array}{l}\mathrm{CD} 14^{+} / 18^{+}: 281 \pm 61 \text { vs. } 264 \pm 38 \text { vs. } \\
116 \pm 16 \times 10^{3} / \mu l\end{array}$ \\
\hline
\end{tabular}


TABLE 12 | Continued

\begin{tabular}{|c|c|c|c|c|c|c|c|c|c|c|c|}
\hline References & $\begin{array}{c}\text { Age } \\
\text { (days) }\end{array}$ & $\begin{array}{l}\text { Lavages } \\
\text { (n) }\end{array}$ & $\begin{array}{l}\text { Volume } \\
(\mathrm{ml} / \mathrm{kg})\end{array}$ & $\begin{array}{l}\text { PIP/PEEP* } \\
\text { (mbar) }\end{array}$ & $\begin{array}{c}V_{\top}^{\#} \\
(\mathrm{ml} / \mathrm{kg})\end{array}$ & $\begin{array}{l}\text { study I. }{ }^{\$} \\
\text { (h) }\end{array}$ & $\begin{array}{c}\mathrm{C}_{\mathrm{rs}}^{\S} \\
(\mathrm{ml} / \mathrm{mbar} / \mathrm{kg})\end{array}$ & $\begin{array}{c}\mathbf{R}_{\mathrm{rs}}^{\mathbb{I I}} \\
\left(\mathrm{mbar} / /^{*} \mathrm{sec}\right)\end{array}$ & $\mathrm{FRC}^{\dagger}(\mathrm{ml} / \mathrm{kg})$ & Intervention & Immunologic response \\
\hline \multirow[t]{6}{*}{$\begin{array}{l}\text { Preuß et al. } \\
\text { (2012a) (triple-hit: } \\
\text { lavage } \\
\text { overventilation } \\
\text { LPS) }\end{array}$} & \multirow[t]{6}{*}{$3-6$} & \multirow[t]{6}{*}{$16 \pm 3$} & \multirow[t]{6}{*}{30} & \multirow[t]{6}{*}{$/ 6$} & \multirow[t]{6}{*}{7} & \multirow[t]{6}{*}{72} & \multirow[t]{6}{*}{$\begin{array}{l}1.2 \pm 0.2 \rightarrow \\
0.5 \pm 0.2\end{array}$} & \multirow[t]{6}{*}{$\begin{array}{r}57 \pm 18 \rightarrow \\
109 \pm 49\end{array}$} & \multirow[t]{6}{*}{-} & \multirow[t]{6}{*}{$\begin{array}{l}\text { Poractant alfa and } \\
\text { PIP2 }^{\circ}\end{array}$} & $\begin{array}{l}\text { Cells: } 555 \pm 238 \text { vs. } 379 \pm 179 \text { vs. } \\
149 \pm 130 \times 10^{3} / \mu l \\
C D 14^{+} / 18^{+}: 331 \pm 96 \text { vs. } 244 \pm 46 \text { vs. } \\
99 \pm 30 \times 10^{3} / \mu l\end{array}$ \\
\hline & & & & & & & & & & & $\begin{array}{l}\text { Tissue amphiregulin: } 1.0 \pm 1.3 \mathrm{vs} . \\
1.8 \pm 2.2 \mathrm{vs} .0 .1 \pm 0.1 \mathrm{rU}\end{array}$ \\
\hline & & & & & & & & & & & $\begin{array}{l}\text { Tissue TGF- } 1 \beta: 1.0 \pm 0.6 \text { vs. } 0.9 \pm 0.7 \text { vs. } \\
0.02 \pm 0.01 \mathrm{rU}\end{array}$ \\
\hline & & & & & & & & & & & $\begin{array}{l}\text { Tissue IL-6: } 1.0 \pm 0.5 \text { vs. } 2.3 \pm 1.4 \text { vs. } \\
0.003 \pm 0.001 \mathrm{rU}\end{array}$ \\
\hline & & & & & & & & & & & $\begin{array}{l}\text { Tissue aSMase activity: } 2.6 \pm 0.3 \mathrm{vs.} \\
1.9 \pm 0.2 \mathrm{vs.} 1.8 \pm 0.2 \mathrm{nmol} / \mathrm{g} \text { protein } / \mathrm{h}\end{array}$ \\
\hline & & & & & & & & & & & $\begin{array}{l}\text { Tissue ceramide: } 2.4 \pm 0.4 \text { vs. } 2.1 \pm 0.2 \\
\text { vs. } 2.0 \pm 0.5 \mathrm{nmol} / \mathrm{mg}\end{array}$ \\
\hline Qin et al. (2013) & $?$ & $?$ & 35 & $\begin{aligned} 10 & \rightarrow 20 / 2 \\
& \rightarrow 4\end{aligned}$ & $?$ & 48 & - & - & - & CMV vs. HFOVח & $\begin{array}{l}\text { Lesser AEC migration, lesser giant lamellar } \\
\text { bodies, lesser vacuoles and cell } \\
\text { polymorphisms }\end{array}$ \\
\hline \multirow[t]{2}{*}{ Fu et al. (2013) } & \multirow[t]{2}{*}{$0-3$} & \multirow[t]{2}{*}{-} & \multirow[t]{2}{*}{35} & \multirow[t]{2}{*}{$\begin{aligned} 10 & \rightarrow 20 / 2 \\
& \rightarrow 4\end{aligned}$} & \multirow[t]{2}{*}{$?$} & \multirow[t]{2}{*}{48} & \multirow[t]{2}{*}{-} & \multirow[t]{2}{*}{-} & \multirow[t]{2}{*}{-} & \multirow[t]{2}{*}{ CMV vs. HFOV } & $\begin{array}{l}\text { Alveolar macophages: } 76 \pm 14 \text { vs. } \\
69 \pm 8 \%\end{array}$ \\
\hline & & & & & & & & & & & $\begin{array}{l}\text { Alveolar red blood cells: } 380 \pm 15 \text { vs. } \\
230 \pm 18 / 100 \text { alveoli }\end{array}$ \\
\hline \multirow[t]{3}{*}{ Yang et al. (2013) } & \multirow[t]{3}{*}{$7-14$} & \multirow[t]{3}{*}{$?$} & \multirow[t]{3}{*}{10} & \multirow[t]{3}{*}{15} & \multirow[t]{3}{*}{8} & \multirow[t]{3}{*}{24} & \multirow{3}{*}{$\begin{array}{c}0.74 \pm 0.03 \rightarrow \\
0.46 \pm 0.02\end{array}$} & \multirow[t]{3}{*}{-} & \multirow[t]{3}{*}{-} & \multirow{3}{*}{$\begin{array}{l}\text { Surfactant and } \\
\text { Budenoside }\end{array}$} & 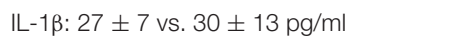 \\
\hline & & & & & & & & & & & TNF- $\alpha: 1.0 \pm 0.2$ vs. $0.9 \pm 0.2 \mathrm{ng} / \mathrm{ml}$ \\
\hline & & & & & & & & & & & Lung injury score: 15 (12-18) vs. 12 (7-13) \\
\hline \multirow{4}{*}{$\begin{array}{l}\text { Preuß et al. (2014) } \\
\text { (triple-hit: lavage } \\
\text { overventilation } \\
\text { LPS) }\end{array}$} & \multirow[t]{4}{*}{$3-6$} & $15 \pm 1$ & 30 & $/ 6$ & 7 & 72 & $\begin{array}{c}1.16 \pm 0.31 \rightarrow \\
0.30 \pm 0.06\end{array}$ & $\begin{array}{r}60 \pm 18 \rightarrow \\
112 \pm 52\end{array}$ & - & $\begin{array}{l}\text { Poractant alfa and } \\
\text { DOPG }^{y}\end{array}$ & $\begin{array}{l}\text { sPLA }_{2}: 2.0 \pm 0.3 \text { vs. } 0.9 \pm 0.2 \text { vs. } \\
0.2 \pm 0.2 \mathrm{pg} / \mathrm{ml}\end{array}$ \\
\hline & & & & & & & & & & & $\begin{array}{l}\text { TNF- } \alpha: 0.24 \pm 0.05 \text { vs. } 0.19 \pm 0.01 \text { vs. } \\
0.10 \pm 0.01 \mathrm{pg} / \mathrm{ml}\end{array}$ \\
\hline & & & & & & & & & & & $\begin{array}{l}\text { Cells: } 448 \pm 222 \text { vs. } 457 \pm 228 \text { vs. } \\
73 \pm 79 \times 10^{3} / \mu l\end{array}$ \\
\hline & & & & & & & & & & & $\begin{array}{l}\mathrm{CD}_{14}+18^{+}: 287 \pm 58 \text { vs. } 340 \pm 65 \text { vs. } \\
52 \pm 6 \times 10^{3} / \mu 1\end{array}$ \\
\hline
\end{tabular}


TABLE 12 | Continued

\begin{tabular}{|c|c|c|c|c|c|c|c|c|c|c|c|}
\hline References & $\begin{array}{c}\text { Age } \\
\text { (days) }\end{array}$ & $\begin{array}{l}\text { Lavages } \\
\text { (n) }\end{array}$ & $\begin{array}{l}\text { Volume } \\
(\mathrm{ml} / \mathrm{kg})\end{array}$ & $\begin{array}{l}\text { PIP/PEEP* } \\
\text { (mbar) }\end{array}$ & $\begin{array}{c}V_{\top}^{\#} \\
(\mathrm{ml} / \mathrm{kg})\end{array}$ & $\begin{array}{l}\text { study l. } \$ \\
\text { (h) }\end{array}$ & $\begin{array}{c}\mathbf{C}_{\mathrm{rs}}^{\S} \\
(\mathrm{ml} / \mathrm{mbar} / \mathrm{kg})\end{array}$ & $\begin{array}{c}\mathbf{R}_{\mathrm{rs}}^{\mathbb{I I}} \\
\left(\mathrm{mbar} / \mathrm{l}^{*} \mathrm{sec}\right)\end{array}$ & $\mathrm{FRC}^{\dagger}(\mathrm{ml} / \mathrm{kg})$ & Intervention & Immunologic response \\
\hline & & & & & & & & & & & $\begin{array}{l}\text { Tissue amphiregulin: } 1.0 \pm 1.7 \mathrm{vs.} \\
0.6 \pm 0.7 \text { vs. } 0.1 \pm 0.2 \mathrm{rU}\end{array}$ \\
\hline & & & & & & & & & & & $\begin{array}{l}\text { Tissue TGF- } \beta 1: 1.0 \pm 0.8 \text { vs. } 1.4 \pm 0.8 \text { vs. } \\
0.02 \pm 0.01 \mathrm{rU}\end{array}$ \\
\hline & & & & & & & & & & & $\begin{array}{l}\text { AEC apoptosis: } 30 \pm 13 \text { vs. } 35 \pm 10 \text { vs. } \\
15 \pm 6 \text { of } 200 \text { AEC }\end{array}$ \\
\hline \multirow{4}{*}{$\begin{array}{l}\text { Spengler et al. } \\
\text { (2018) (triple-hit: } \\
\text { lavage } \\
\text { overventilation } \\
\text { LPS) }\end{array}$} & \multirow[t]{4}{*}{$2-7$} & \multirow[t]{4}{*}{$17 \pm 2$} & \multirow[t]{4}{*}{30} & \multirow[t]{4}{*}{$/ 6$} & \multirow[t]{4}{*}{7} & \multirow[t]{4}{*}{72} & \multirow[t]{4}{*}{$\begin{array}{l}1.2 \pm 0.4 \rightarrow \\
0.4 \pm 0.1\end{array}$} & \multirow[t]{4}{*}{$\begin{array}{r}71 \pm 19 \rightarrow \\
150 \pm 62\end{array}$} & \multirow[t]{4}{*}{-} & \multirow[t]{4}{*}{$\begin{array}{l}\text { Poractant alfa and } \\
\text { IP3, PIP2, } \\
\text { POPG }{ }^{\text {, }} \text { 'DOPG }\end{array}$} & $\begin{array}{l}\text { Tissue aSMase activity: } 49 \pm 4 \text { vs. } 42 \pm 5 \\
\text { vs. } 20 \pm 3 \text { vs. } 32 \pm 2 \text { vs. } 40 \pm 7 \text { vs. } \\
40 \pm 3 \mathrm{nmol} / \mathrm{mg} / \mathrm{h}\end{array}$ \\
\hline & & & & & & & & & & & $\begin{array}{l}\text { Tissue ceramide: } 1.2 \pm 0.2 \text { vs. } 1.1 \pm 0.1 \\
\text { vs. } 0.6 \pm 0.1 \mathrm{vs.} 1.0 \pm 0.1 \text { vs. } 1.1 \pm 0.1 \\
\text { vs. } 1.1 \pm 0.1 \mathrm{pmol} / \mathrm{mg}\end{array}$ \\
\hline & & & & & & & & & & & $\begin{array}{l}\text { Tissue NLRP } 3^{\infty}: 100 \pm 7 \text { vs. } 91 \pm 9 \text { vs. } \\
32 \pm 9 \text { vs. } 87 \pm 6 \text { vs. } 82 \pm 12 \text { vs. } \\
81 \pm 9 \%\end{array}$ \\
\hline & & & & & & & & & & & $\begin{array}{l}\text { Tissue caspase- } 1: 100 \pm 5 \text { vs. } 91 \pm 23 \\
\text { vs. } 35 \pm 13 \text { vs. } 88 \pm 16 \text { vs. } 103 \pm 21 \text { vs. } \\
84 \pm 18 \%\end{array}$ \\
\hline
\end{tabular}

Further data from (Spengler et al., 2018): tissue IL-1B: $100 \pm 11$ vs. $99 \pm 17$ vs. $33 \pm 16$ vs. $86 \pm 24$ vs. $92 \pm 19$ vs. $75 \pm 16 \%$. Tissue IL-18: $100 \pm 12$ vs. $99 \pm 17$ vs. $34 \pm 8$ vs. $97 \pm 17$ vs. $95 \pm 14$ vs. $80 \pm 24 \%$, Tissue IkBa: $8 \pm 4$ vs. $12 \pm 7$ vs. $66 \pm 16$ vs. $50 \pm 15$ vs. $31 \pm 9$ vs. $26 \pm 6 \%$, Tissue /kB-kinase: $99 \pm 4$ vs. $88 \pm 4$ vs. $23 \pm 12$ vs. $33 \pm 11$ vs. $54 \pm 21$ vs. $65 \pm 15 \%$, Tissue TGF- $-\beta 1: 103 \pm 2$ vs. $97 \pm 7$ vs. $36 \pm 12$ vs. $95 \pm 24$ vs. $93 \pm 25$ vs. $85 \pm 34 \%$, Tissue IFN- $\gamma: 100 \pm 13$ vs. $90 \pm 13$ vs. $26 \pm 15$ vs. $89 \pm 21$ vs. $94 \pm 14$ vs. $76 \pm 21 \%$, Tissue elastin: $101 \pm 5$ vs. $97 \pm 6$ vs. $49 \pm 5$ vs. $85 \pm 7$ vs. $83 \pm 14$ vs. $51 \pm 8 \%$, Tissue MMP- $1 \equiv: 101 \pm 6$ vs. $91 \pm 13$ vs. $43 \pm 7$ vs. $65 \pm 17$ vs. $80 \pm 17$ vs. $52 \pm 12 \%$, Albumin: $378 \pm 36$ vs. $368 \pm 16$ vs. $109 \pm 15$ vs. $357 \pm 24$ vs. $327 \pm 16$ vs. $124 \pm 9 \mu \mathrm{g} / \mathrm{ml}$, Blood SP-D: $326 \pm 19$ vs. $326 \pm 13$ vs. $65 \pm 7$ vs. $288 \pm 16$ vs. $260 \pm 17$ vs. $126 \pm 6 \mathrm{ng} / \mathrm{ml}$, AEC apoptosis: $15 \pm 5$ vs. $21 \pm 6$ vs. $12 \pm 2$ vs. $11 \pm 3$ vs. n.d. vs. $9 \pm 3 \%, M M P-8 \equiv: 26 \pm 8$ vs. $24 \pm 4$ vs. $4 \pm 0.5$ vs. $23 \pm 7$ vs. $25 \pm 8$ vs. $5 \pm 1$ ng/ml, sPLA2: $20 \pm 10$ vs. $15 \pm 6$ vs. $13 \pm 11$ vs. $12 \pm 11$ vs. $28 \pm 8$ vs. $27 \pm 9$ pg/ml. PIP/PEEP, peak inspiratory pressure/positive end-exspiratory pressure; " $V_{T}$, tidal volume; ${ }^{\$}$ study l., study length; ${ }^{\circledR} C_{r s}$, compliance of the respiratory system: "Rrs, resistance of the respiratory system; ${ }^{\dagger} F R C$, functional residual capacity;

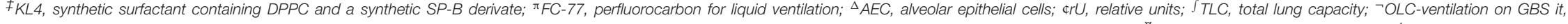
open lung concept ventilation secondary to additional intratracheal instillation of group B streptococci; SA/LA-ratio, small aggregate/large aggregate surfactant ratio; ${ }^{\mathbb{a}} / K K$-NBD peptide, NF-KB antibody; ${ }^{\circ}$ MK886, 5 -lipoxygenase inhibitor; ^ $a$ aU, arbitrary units; ' ${ }^{2}$ SSMase, acid sphingomyelinase; ${ }^{\circledR}$ IP3, myo-inositol-1,2,6-trisphosphate; ${ }^{\circ}$ PIP2, L- $\alpha$-phosphatidyl-L-myo-inositol-3,5-bisphosphate; $\cap$ CMV/HFOV, conventional mechanical ventilation/high-frequency oscillatory ventilation; ${ }^{\forall} D O P G, 18: 1 / 18: 1$-dioeoyl-phosphatidylglycerol; $\square$ POPG, palmitoyl-oleoyl-phosphatidylglycerol; ${ }^{\infty} N L R P 3$, nucleotide-binding domain, leucine-rich repeat-containing protein-3 (inflammasome); $=$ MMP-1/8, matrix metalloproteinase-1; n.d., not determined.

PIP/PEEP, $C_{r s}, R_{r s}, F R C$, immunologic response: arrow $(\rightarrow)$ delineates changes by the lung injury protocol (i.e., repeated airway lavage); vs. delineates differences secondary to a specific intervention (first place control group, second place intervention group data).

Immunologic response parameters are from broncho-alveolar lavage fluid (BALF) unless specified otherwise. 
TABLE 13 | Newborn animal models of acute respiratory distress syndrome (NARDS) involving mechanical ventilation.

\begin{tabular}{|c|c|c|c|c|c|c|c|c|}
\hline Species & Availability & Costs & $\begin{array}{l}\text { Clinical } \\
\text { relevance }\end{array}$ & $\begin{array}{l}\text { Max. period of } \\
\text { mechanical } \\
\text { ventilation (d) }\end{array}$ & $\begin{array}{l}\text { Common types of } \\
\text { lung injury (see } \\
\text { below) }\end{array}$ & TLR4 HVR* (\%) & $\begin{array}{l}\text { Pulmonary } \\
\text { intravascular } \\
\text { macrophages }\end{array}$ & LPS\# sensitivity \\
\hline Baboon & Scarce & Very high & Very high & 28 & $\mathrm{IRDS}^{1}, \mathrm{HO}^{2}$ & 95 & $\mathrm{Few}^{3 \$}$ & Intermediate \\
\hline Pig & Good & Intermediate & High & 4 & $\begin{array}{l}\text { L, OV, ITLPS, MAS, } \\
\mathrm{HO}, \mathrm{IPI}\end{array}$ & $\sim 80^{4}$ & Yes $^{5}$ & Intermediate ${ }^{6}$ \\
\hline Sheep & Seasonal & High & High & $<1$ & $\begin{array}{l}\text { IRDS, IT/ALPS, } \mathrm{HCL}^{9} \\
\mathrm{MAS}^{10}, \mathrm{IPI}^{11}, \mathrm{HO}^{12}\end{array}$ & $83-85^{7}$ & Yes $^{3,5}$ & $\mathrm{High}^{8}$ \\
\hline Rabbit & Good & Low & Low & $<1$ & $\mathrm{~L}, \mathrm{MAS}^{13}$ & 57 & No & Intermediate \\
\hline Guinea pig & Good & Low & Low & $<1$ & IRDS, HO & $?$ & No & Low \\
\hline Rat & Good & Low & Low & $<1$ & $\begin{array}{l}\mathrm{HO}^{14}, \mathrm{OV}^{15}, \mathrm{HCL}^{15} \\
\mathrm{IPLPS}^{17}\end{array}$ & 48 & $\mathrm{No}^{\$}$ & $\operatorname{Low}^{16}$ \\
\hline
\end{tabular}

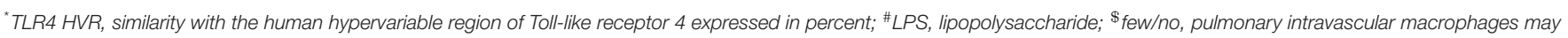
be induced, such as in human kind.

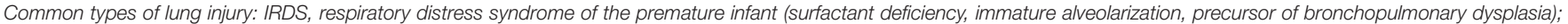

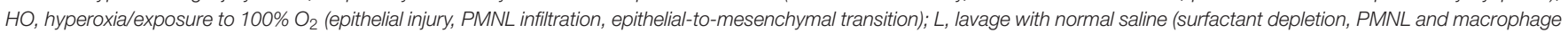

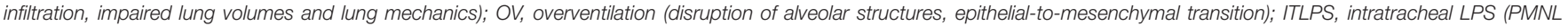

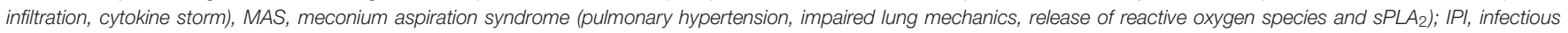

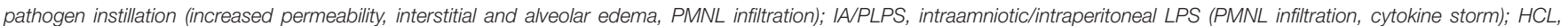
hydrochloric acid lavage (disruption of alveolar and capillary structures, PMNL infiltration).

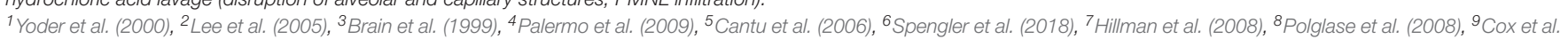

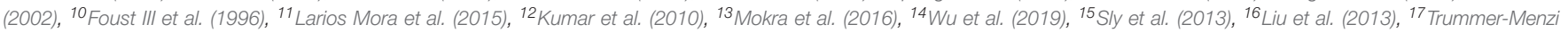
et al. (2012).

the advantage of being able to transfer findings from neonatal to more mature animal models (Schouten et al., 2015).

\section{Future Direction: Customizing Innate Immunity}

In the majority of cases NARDS is elicited by the invasion of PAMPS (pathogen-associated molecular patterns) into the lungs which may be bacteria, meconium, droplets of bile, amniotic fluid, or swallowed blood among others. These pathogens may be bound by macrophages with the help of surface lectins or Toll-like receptors also inducing macrophage activation. The surfactant proteins $\mathrm{A}$ and $\mathrm{D}$ are collectins and provide a first line defense next to molecules of the ficolin and pentraxin families which act as opsonins together with the complement system. Of paramount significance is the early invasion of PMNL to the site of inflammation (alveolar epithelium, capillary endothelium of the lung) mediated by CAMs (cellular adhesion molecules, interaction with PMNL integrins) and selectins (interaction with carbohydrate ligands). In addition, cytokines, such as TNF- $\alpha$, IL- $1 \beta$, and chemokines move PMNL and plasma molecules to the site of inflammation or tissue damage. The clearance of pathogens and cell debris is followed by remodeling and regeneration of pulmonary tissue including epithelialto-mesenchymal transition (EMT) and the proliferation and mobilization of fibroblasts (being responsible for the rapidly declining $\mathrm{C}_{\mathrm{rs}}$ (compliance of the respiratory system) after some days of mechanical ventilation).

Limiting damage and repair of lung tissue by the newborn organism's innate immunity without completely uncoupling the means of defense-especially in case of infectious pathogensseems to be the distinguished task for future research by the use of the piglet lavage/meconium aspiration model. Considering the complexity of the innate immunity as very shortly outlined above, many approaches are possible but should probably tackle major anti-inflammatory pathways instead of single-even importantmolecules to overcome the phenomenon of redundant activation of e.g., many cytokines [such as blocking IL- 8 by specific antibodies may upregulate IL-8 production in experimental NARDS (Ankermann et al., 2005b)].

\section{Conclusions}

The newborn piglet serves as an excellent, robust animal model to study severe neonatal lung diseases with high mortality. The research of three decades has described a myriad of physiological and immunological parameters of the newborn piglet as one of the best studied animal models ever. Most of the clinical, physiological, biological, and pathological changes in NARDS can be also found in the two well-established models presented here: the meconium aspiration model and the lavage model. While most of the research was conducted in the last decade and has slowed down lately, many new insights into the innate immune system should bring up new treatments to specifically tackle important pro-inflammatory upstream pathways. For the benefit of many newborns with life-threatening nARDS future research on the newborn piglet models may greatly help to conquer new specific treatment modalities.

\section{AUTHOR CONTRIBUTIONS}

DS and NR collected the physiologic data from three experiments and screened eligible publications for the systematic review. MK wrote the first draft of the manuscript. All authors contributed to a manuscript revision and approved the final version of the manuscript. 


\section{REFERENCES}

Abubakar, K., Schmidt, B., Monkmann, S., Webber, C., deSa, D., and Roberts, R. (1998). Heparin improves gas exchange during experimental acute lung injury in newborn piglets. Am. J. Respir. Crit. Care Med. 158, 1620-1625. doi: $10.1164 /$ ajrccm.158.5.9803041

Amdi, C., Krogh, U., Flummer, C., Okjsbjerg, N., Hansen, C. F., and Theil, P. K. (2013). Intrauterine growth restricted piglets defined by their head shape ingest insufficient amounts of colostrum. J. Anim. Sci. 91, 5605-5613. doi: $10.2527 /$ jas.2013-6824

Angert, R. M., Pilon, A. L., Chester, D., and Davis, J. M. (2007). CC10 reduces inflammation in meconium aspiration syndrome in newborn piglets. Pediatr. Res. 62, 684-688. doi: 10.1203/PDR.0b013e31815a5632

Ankermann, T., Reisner, A., Wiemann, T., Koehler, H., Krams, M., and Krause, M. F. (2006). Intrapulmonary application of a 5-lipoxygenase inhibitor using surfactant as a carrier reduces lung edema in a piglet model of airway lavage. Pediatr. Pulmonol. 41, 452-462. doi: 10.1002/ppul.20392

Ankermann, T., Reisner, A., Wiemann, T., Krams, M., Köhler, H., and Krause, M. F. (2005a). Topical inhibition of nuclear factor-kappaB enhances reduction in lung edema by surfactant in a piglet model of airway lavage. Crit. Care Med. 33, 1384-1391. doi: 10.1097/01.CCM.0000166371.18066.5E

Ankermann, T., Wiemann, T., Reisner, A., Orlowska-Volk, M., Köhler, H., and Krause, M. F. (2005b). Topical interleukin- 8 antibody attracts leukocytes in a piglet lavage model. Intensive Care Med. 31, 272-280. doi: 10.1007/s00134-004-2464-5

Anzueto, A., Baughman, R. P., Guntupalli, K. K., Weg, J. G., Wiedemann, H. P., Raventós, A. A., et al. (1996). Aerosolized surfactant in adults with sepsisinduced acute respiratory distress syndrome. N. Engl. J. Med. 334, 1417-1421. doi: 10.1056/NEJM199605303342201

Aziz, S. M., Pauly, T. H., and Gillespie, M. N. (1993). Intrinsic microbicidal activity and pulmonary hypertension in isolated newborn piglet lungs. Pediatr. Res. 34, 32-37. doi: 10.1203/00006450-19930700000009

Balaraman, V., Meister, J., Ku, T. L., Sood, S. L., Tam, E., Killeen, J., et al. (1998). Lavage administration of dilute surfactants after acute lung injury in neonatal piglets. Am. J. Respir. Crit. Care Med. 158, 12-17. doi: $10.1164 /$ ajrccm.158.1.9704119

Barnes, P. J. (2004). Ceramide lances the lungs. Nat. Med. 10, 130-131. doi: 10.1038/nm0204-130

Bern, R. A., van der Loos, C. M., van Woensel, J. B. M., and Bos, A. P. (2010). Cleaved caspase-3 in lung epithelium of children who died with acute respiratory distress syndrome. Pediatr. Crit. Care Med. 11, 556-560. doi: 10.1097/PCC.0b013e3181d5063c

Bernard, G. R., Luce, J. M., Sprung, C. L., Rinaldo, J. E., Tate, R. M., Sibbald, W. J., et al. (1987). High-dose corticosteroids in patients with the adult respiratory distress syndrome. N. Engl. J. Med. 317, 1565-1570. doi: 10.1056/NEJM198712173172504

Billman Thorgersen, E., Pharo, A., Haverson, K., Axelsen, A. K., Gaustad, P., Kotwal, G. J., et al. (2009). Inhibition of complement and CD14 attenuates the Escherichia coli-induced inflammatory response in porcine whole blood. Infect. Immun. 77, 725-732. doi: 10.1128/IAI.01305-08

Brain, J. D., Molina, R. M., DeCamp, M. M., and Warner, A. E. (1999). Pulmonary intravascular macrophages: their contribution to the mononuclear phagocyte system in 13 species. Am. J. Physiol. Cell. Mol. Physiol. 276, L146-L154. doi: 10.1152/ajplung.1999.276.1.L146

Calfee, C. S., Janz, D. R., Bernard, G. R., May, A. K., Kangelaris, K. N., Matthay, M. A., et al. (2015). Distinct molecular phenotypes of direct vs indirect ARDS in single-center and multicenter studies. Chest 147, 1539-1548. doi: 10.1378/chest.14-2454

Cantu, E., Gaca, J. G., Palestrant, D., Baig, K., Lukes, D. J., Gibson, S. E., et al. (2006). Depletion of pulmonary intravascular macrophages prevents hyperacute pulmonary xenograft dysfunction. Transplantation $27,1157-1164$. doi: 10.1097/01.tp.0000169758.57679.2a

Castellheim, A., Lindenskov, P. H., Pharo, A., Fung, M., Saugstad, O. D., and Mollnes, T. E. (2004). Meconium is a potent activator of complement in human serum and in piglets. Pediatr. Res. 55, 310-318. doi: 10.1203/01.PDR.0000100902.76021.8E
Castellheim, A., Lindenskov, P. H. H., Pharo, A., Aamodt, G., Saugstad, O. D., and Mollnes, T. E. (2005). Meconium aspiration syndrome induces complementassociated systemic inflammatory response in newborn piglets. Scand. J. Immunol. 61, 217-225. doi: 10.1111/j.1365-3083.2005.01532.x

Chada, M., Nögel, S., Schmidt, A. M., Rückel, A., Bosselmann, S., Walther, J., et al. (2008). Anakinra (IL-1R antagonist) lowers pulmonary artery pressure in a neonatal surfactant depleted piglet model. Pediatr. Pulmonol. 43, 851-857. doi: 10.1002/ppul.20851

Chandra, S., Davis, J. M., Drexler, S., Kowalewska, J., Chester, D., Koo, H. C., et al. (2003). Safety and efficacy of intratracheal recombinant human Clara cell protein in a newborn piglet model of acute lung injury. Pediatr. Res. 54, 509-515. doi: 10.1203/01.PDR.0000081300.49749.87

Corrèa, R. R. M., Rocha, L. P., Petrini, C. G., Teixeira, V. D. A., and Castro, E. C. D. (2014). Influence of cause of death on body and internal organs weight in perinatal autopsies. Rev. Bras. Ginecol. Obstet. 36, 23-28. doi: 10.1590/S0100-72032014000100006

Cox, C. A., Fox, W. W., Weiss, C. M., Wolfson, M. R., and Shaffer, T. H. (2002). Liquid ventilation: gas exchange, perfluorochemical uptake, and biodistribution in an acute lung injury. Pediatr. Crit. Care Med. 3, 288-296. doi: 10.1097/00130478-200207000-00017

Dahmer, M. K., Quasney, M. W., Sapru, A., Gildengorin, G., Curley, M. A. Q., Matthay, M. A., et al. (2018). Interleukin-1 receptor antagonist is associated with pediatric acute respiratory distress syndrome and worse outcomes in children with acute respiratory failure. Pediatr. Crit. Care Med. 19, 930-938. doi: $10.1097 /$ PCC. 0000000000001680

Dargaville, P. A., Mills, J. F., Headley, B. M., Chan, Y., Coleman, L., Loughnan, P. M., et al. (2003). Therapeutic lung lavage in the piglet model of meconium aspiration syndrome. Am. J. Respir. Crit. Care Med. 168, 456-463. doi: $10.1164 / \mathrm{rccm} .200301-1210 \mathrm{C}$

Davey, A. M., Becker, J. D., and Davis, J. M. (1993). Meconium aspiration syndrome: Physiological and inflammatory changes in a newborn piglet model. Pediatr. Pulmonol. 16, 101-108. doi: 10.1002/ppul.1950160205

Davis, J. M., Dickerson, B., Metlay, L., and Penney, D. P. (1991). Differential effects of oxygen and barotrauma on lung injury in the neonatal piglet. Pediatr. Pulmonol. 10, 157-163. doi: 10.1002/ppul.1950100305

Davis, J. M., Penney, D. P., Notter, R. H., Metlay, L., Dickerson, B., and Shapiro, D. L. (1989). Lung injury in the neonatal piglet caused by hyperoxia and mechanical ventilation. J. Appl. Physiol. 67, 1007-1012. doi: 10.1152/jappl.1989.67.3.1007

Davis, J. M., Robbins, C. G., Anderson, T., Sahqal, N., Genen, L., Tierney, J., et al. (1995). The effects of hyperoxia, mechanical ventilation, and dexamethasone on pulmonary antioxidant enzyme activity in the newborn piglet. Pediatr. Pulmonol. 20, 107-111. doi: 10.1002/ppul.1950200210

de Benedictis, F. M., and Bush, A. (2012). Corticosteroids in respiratory diseases in children. Am. J. Respir. Crit. Care Med. 185, 12-23. doi: 10.1164/rccm.201107-1174CI

de Blic, J., Midulla, F., Barbato, A., Clement, A., Dab, I., Eber, E., et al. (2000). Bronchoalveolar lavage in children. Eur. Respir. J. 15, 217-231. doi: $10.1183 / 09031936.00 .15121700$

De Luca, D. (2019). Personalising care of acute respiratory distress syndrome according to patient's age. Lancet Respir. Med. 7, 100-101. doi: 10.1016/S2213-2600(18)30429-6

De Luca, D., Baroni, S., Vento, G., Piastra, M., Pietrini, D., Romitelli, F., et al. (2008). Secretory phospholipase A2 and neonatal respiratory distress: pilot study on broncho-alveolar lavage. Intensive Care Med. 34, 1858-1864. doi: 10.1007/s00134-008-1224-3

De Luca, D., Lopez-Rodriguez, E., Minucci, A., Vendittelli, F., Gentile, L., Stival, E., et al. (2013). Clinical and biological role of secretory phospholipase A2 in acute respiratory distress syndrome infants. Crit. Care 17:R163. doi: 10.1186/cc12842

De Luca, D., Minucci, A., Cogo, P., Capoluongo, E. D., Conti, G., Pietrini, D., et al. (2011). Secretory phospholipase A2 pathway during pediatric acute respiratory distress syndrome: a preliminary study. Pediatr. Crit. Care Med. 12, e20-e24. doi: 10.1097/PCC.0b013e3181dbe95e

De Luca, D., Minucci, A., Zecca, E., Piastra, M., Pietrini, D., Carnielli, V. P., et al. (2009). Bile acids cause secretory phospholipase A2 activity enhancement, revertible by exogenous surfactant administration. Intensive Care Med. 35, 321-326. doi: 10.1007/s00134-008-1321-3 
De Luca, D., van Kaam, A. H., Tingay, D. G., Courtney, S. E., Danhaive, O., Carnielli, V. P., et al. (2017). The Montreux definition of neonatal ARDS: biological and clinical background behind the description of a new entity. Lancet Respir. Med. 5, 657-666. doi: 10.1016/S2213-2600(17)30214-X

De Paepe, M. E., Friedman, R. M., Gündogan, F., and Pinar, H. (2005). Postmortem lung weight/body weight standards for term and preterm infants. Pediatr. Pulmonol. 40, 445-448. doi: 10.1002/ppul.20218

De Paepe, M. E., Shapiro, S., Hansen, K., and Gündogan, F. (2014). Postmortem lung volume/body weight standards for term and preterm infants. Pediatr. Pulmonol. 49, 60-66. doi: 10.1002/ppul.22818

del Riccio, V., van Tuyl, M., and Post, M. (2004). Apoptosis in lung development and neonatal lung injury. Pediatr. Res. 55, 183-189. doi: 10.1203/01.PDR.0000103930.93849.B2

Dentener, M. A., Bazil, V., von Asmuth, E. J., Ceska, M., and Buurman, W. A. (1993). Involvement in lipopolysaccharide-induced tumor necrosis factoralpha, IL- 6 and IL- 8 release by human monocytes and alveolar macrophages. J. Immunol. 150, 2885-2891.

Dos Santos, G., Kutuzov, M. A., and Ridge, K. M. (2012). The inflammasome in lung disease. Am. J. Physiol. Lung Cell. Mol. Physiol. 303, L627-L633. doi: 10.1152/ajplung.00225.2012

Drago, B. B., Kaimura, D., Rovnaghi, C. R., Schwingshackl, A., Rayburn, M., Meduri, U., et al. (2015). Double-blind, placebo-controlled pilot randomized trial of methylprednisolone infusion in pediatric acute respiratory distress syndrome. Pediatr. Crit. Care Med. 16, e74-e81. doi: 10.1097/PCC.0000000000000349

Ehlert, C. A., Truog, W. E., Thibeault, D. W., Garg, U., Norberg, M., Rezaiekhaligh, M., et al. (2006). Hyperoxia and tidal volume: independent and combined effects on neonatal pulmonary inflammation. Biol. Neonate 90, 89-97. doi: 10.1159/000092005

Eisenhauer, C. L., Matsuda, L. S., and Uyehara, C. F. T. (1994). Normal physiologic values of neonatal pigs and the effects of isoflurane and pentobarbital anesthesia. Lab. Anim. Sci. 44, 245-252.

Endo, S., Sato, N., Nakae, H., Yamada, Y., Makabe, H., Abe, H., et al. (2002). Surfactant protein A and D (SP-A, SP-D) levels in pathients with septic ARDS. Res. Commun. Mol. Pathol. Pharmacol. 111, 245-251.

Fahy, R. J., Lichtenberger, F., McKeegan, C. B., Nuovo, G. J., Marsh, C. B., and Wewers, M. D. (2003). The acute respiratory distress syndrome. A role for transforming growth factor-beta1. Am. J. Respir. Cell. Mol. Biol. 28, 499-503. doi: 10.1165/rcmb.2002-0092OC

Farmer, C., Robertson, P., Xiao, C. W., Rehfeldt, C., and Kalbe, C. (2016). Exogenous genistein in late gestation: effects on fetal development and sow and piglet performance. Animal 10, 1423-1430. doi: 10.1017/S1751731116000355

Farrell, P. M., and Avery, M. E. (1975). Hyaline membrane disease. Am. Rev. Respir. Dis. 111, 657-688.

Fligiel, S. E., Standiford, T., Fligiel, H. M., Tashkin, D., Strieter, R. M., Warner, R. L., et al. (2006). Matrix metalloproteinases and matrix metalloproteinase inhibitors in acute lung injury. Hum. Pathol. 37, 422-430. doi: 10.1016/j.humpath.2005.11.023

Foust III, R., Tran, N. N., Cox, C., Miller Jr., T. F., Greenspan, J. S., Wolfson, M. R., et al. (1996). Liquid assisted ventilation: an alternative ventilatory strategy for acute meconium aspiration injury. Pediatr. Pulmonol. 21, 316-322. doi: 10. 1002/(SICI)1099-0496(199605)21:5<316::AID-PPUL7>3.0.CO;2-K

Fu, W., Qin, X., You, C., Meng, Q., Zhao, Y., and Zhang, Y. (2013). High frequency oscillatory ventilation versus conventional ventilation in a newborn piglet model with acute lung injury. Respir. Care 58, 824-830. doi: $10.4187 /$ respcare.01972

Fukumoto, J., Fukumoto, I., Parthasarathy, P. T., Cox, R., Huynh, B., Ramanathan, G. K., et al. (2013). NLRP3 deletion protects from hyperoxia-induced acute lung injury. Am. J. Physiol. Cell. Mol. Physiol. 305, C182-C189. doi: 10.1152/ajpcell.00086.2013

Gibson, R. L., Berger, J. I., Redding, G. J., Standaert, T. A., Mayock, D. E., and Truog, W. E. (1994). Effect of nitric oxide synthase inhibition during group B streptococcal sepsis in neonatal piglets. Pediatr. Res. 36, 776-783. doi: 10.1203/00006450-199412000-00016

Giuffrè, M., Geraci, D. M., Bonura, C., Saporito, L., Graziano, G., Insinga, V., et al. (2016). The increasing challenge of multidrug-resistant Gram-negative bacilli. Medicine (Baltimore) 95:e3016. doi: 10.1097/MD.0000000000003016
Glasset, B., Herbin, S., Granier, S. A., Cavalié, L., Lafeuille, E., Guérin, C., et al. (2018). Bacillus cereus, a serious cause of nosocomial infections: epidemiologic and genetic survey. PLoS ONE 13:e0194346. doi: 10.1371/journal.pone.0194346

Göggel, R., Winoto-Morbach, S., Vielhaber, G., Imai, Y., Lindner, K., Brade, L., et al. (2004). PAF-mediated pulmonary edema: a new role for acid sphingomyelinase and ceramide. Nat. Med. 10, 155-160. doi: 10.1038/nm977

Goto, T., Hussein, M. H., Kato, S., Daoud, G. A.-H., Kato, T., Sugiura, T., et al. (2012). Endothelin receptor antagonist attenuates oxidative stress in a neonatal sepsis piglet model. Pediatr. Res. 72, 600-605. doi: 10.1038/pr.2012.134

Grigg, J., and Riedler, J. (2000). Developmental airway cell biology. Am. J. Respir. Crit. Care Med. 162, S52-S55. doi: 10.1164/ajrccm.162.supplement_1.maic-14

He, S. R., Zhang, C., Liu, Y. M., Sun, Y. X., Zhuang, J., Chen, J. M., et al. (2011). Accuracy of the ultrasonic cardiac output monitor in healthy term neonates during postnatal circulatory adaptation. Chin. Med. J. 124, 2284-2289. doi: 10.3760/cma.j.issn.0366-6999.2011.15.008

Herting, E., Möller, O., Schiffmann, J. H., and Robertson, B. (2002). Surfactant improves oxygenation in infants and children with pneumonia and acute respiratory distress syndrome. Acta Paediatr. 91, 1174-1178. doi: 10.1111/j.1651-2227.2002.tb00124.x

Hilgendorff, A., Doerner, M., Rawer, D., Leick, J., Trotter, A., Ebsen, M., et al. (2006). Effects of a recombinant surfactant protein-C-based surfactant on lung function and the pulmonary surfactant system in a model of meconium aspiration syndrome. Crit. Care Med. 34, 203-210. doi: 10.1097/01.CCM.0000190624.77908.E2

Hilgendorff, A., Rawer, D., Doerner, M., Tutdibi, E., Ebsen, M., Schmidt, R., et al. (2003). Synthetic and natural surfactant differentially modulate inflammation after meconium aspiration. Intensive Care Med. 29, 2247-2254. doi: 10.1007/s00134-003-1984-8

Hillman, N. H., Moss, T. J., Nitsos, I., Kramer, B. W., Bachurski, C. J., Ikegami, M., et al. (2008). Toll-like receptors and agonist responses in the developing fetal sheep lung. Pediatr. Res. 63, 388-393. doi: 10.1203/PDR.0b013e3181647b3a

Hoeck, W. G., Ramesha, C. S., Chang, D. J., Fan, N., and Heller, R. A. (1993). Cytoplasmic phospholipase A2 activity and gene expression are stimulated by tumor necrosis factor: dexamethasone blocks the induced synthesis. Proc. Natl. Acad. Sci. U.S.A. 90, 4475-4479. doi: 10.1073/pnas.90.10.4475

Holopainen, R., Aho, H., Laine, J., Halkola, L., and Kääpä, P. (1999b). Nitric oxide inhalation inhibits pulmonary apoptosis but not inflammatory injury in porcine meconium aspiration. Acta Paediatr. 88, 1147-1155. doi: 10.1080/08035259950168243

Holopainen, R., Aho, H., Laine, J., Peuravuori, H., Soukka, H., and Kääpä, P. (1999a). Human meconium has high phospholipase A2 activity and induces cellular injury and apoptosis in piglet lungs. Pediatr. Res. 46, 626-632. doi: 10.1203/00006450-199911000-00022

Holopainen, R., Laine, J., Halkola, L., Aho, H., and Kääpä, P. (2001). Dexamethasone treatment attenuates pulmonary injury in piglet meconium aspiration. Pediatr. Res. 49, 162-168. doi: 10.1203/00006450-200102000-00006

Holopainen, R., Soukka, H., Halkola, L., and Kääpä, P. (2005). Intravenous immunoglobulin $\mathrm{G}$ attenuates pulmonary hypertension but induces local neutrophil influx in meconium aspiration in piglets. Biol. Neonate 87, 221-228. doi: $10.1159 / 000083371$

Husari, A. W., Dbaibo, G. S., Bitar, H., Khayat, A., Panjarian, S., Nasser, M., et al. (2006). Apoptosis and the activity of ceramide, Bax and Bcl-2 in the lungs of neonatal rats exposed to limited and prolonged hyperoxia. Respir. Res. 7:100. doi: 10.1186/1465-9921-7-100

Jeng, M. J., Kou, Y. R., Sheu, C. C., and Hwang, B. (2002). Effects of partial liquid ventilation with FC-77 on acute lung injury in newborn piglets. Pediatr. Pulmonol. 33, 12-21. doi: 10.1002/ppul.10021

Jeng, M. J., Kou, Y. R., Sheu, C. C., and Hwang, B. (2003). Effects of exogenous surfactant supplementation and partial liquid ventilation on acute lung injury induced by wood smoke inhalation in newborn piglets. Crit. Care Med. 31, 1166-1174. doi: 10.1097/01.CCM.0000059312.90697.32

Jeng, M. J., Soong, W. J., Lee, Y. S., Chang, H. L., Shen, C. M., Wang, C. H., et al. (2006). Effects of therapeutic bronchoalveolar lavage and partial liquid ventilation on meconium-aspirated newborn piglets. Crit. Care Med. 34, 1099-1105. doi: 10.1097/01.CCM.0000205662.60832.35

Jones, H. D., Crother, T. R., Gonzalez-Villalobos, R. A., Jupelli, M., Chen, S., Dagvadorj, J., et al. (2014). The NLRP3 inflammasome is required for the 
development of hypoxemia in LPS/mechanical ventilation acute lung injury. Am. J. Respir. Cell. Mol. Biol. 50, 270-280. doi: 10.1165/rcmb.2013-0087OC

Juul, S. E., Kinsella, M. G., Truog, W. E., Gibson, R. L., and Redding, G. J. (1996). Lung hyaluronan decreases during group B streptococcal pneumonia in neonatal piglets. Am. J. Respir. Crit. Care Med. 153, 1567-1570. doi: 10.1164 /ajrccm.153.5.8630603

Kesecioglu, J., Beale, R., Stewart, T. E., Findlay, G. P., Rouby, J.-J., Holzapfel, L., et al. (2009). Exogenous natural surfactant for treatment of acute lung injury and the acute respiratory distress syndrome. Am. J. Respir. Crit. Care Med. 180, 989-994. doi: 10.1164/rccm.200812-1955OC

Khan, A. M., Shabarek, F. M., Faten, M., Kutchback, J. W., and Lally, K. P. (1999). Effects of dexamethasone on meconium aspiration syndrome in newborn piglets. Pediatr. Res. 46, 179-183. doi: 10.1203/00006450-199908000-00009

Khemani, R. G., Smith, L., Lopez-Fernandez, Y. M., Kwok, J., Morzov, R., Klein, M. J., et al. (2019). Paediatric acute respiratory distress syndrome incidence and epidemiology (PARDIE): an international, observational study. Lancet Respir. Med. 7, 115-128. doi: 10.1016/S2213-2600(18)30344-8

Kimura, D., Saravia, J., Rovnaghi, C. R., Meduri, G. U., Schwingshackl, A., Cormier, S. A., et al. (2016). Plasma biomarker analysis in pediatric ARDS: generating future framework from a pilot randomized control trial of methylprednisolone: a framework for identifying plasma biomarkers related to clinical outcomes in pediatric ARDS. Front. Pediatr. 4:31. doi: 10.3389/fped.2016.00031

Kolliputi, N., Galam, L., Parthasarathy, P. T., Tipparaju, S. M., and Lockey, R. F. (2012). NALP-3 inflammasome silencing attenuates ceramideinduced transepithelial permeability. J. Cell Physiol. 227, 3310-3316. doi: $10.1002 /$ jcp. 24026

Korhonen, K., Kiuru, A., Svedström, E., and Kääpä, P. (2004). Pentoxifylline reduces regional inflammatory and ventilatory disturbances in meconium-exposed piglet lungs. Pediatr. Res. 56, 901-906. doi: 10.1203/01.PDR.0000145256.19073.E4

Korhonen, K., Soukka, H., Halkola, L., Peuravuori, H., Aho, H., Pulkki, K., et al. (2003). Meconium induces only localized inflammatory lung injury in piglets. Pediatr. Res. 54, 192-197. doi: 10.1203/01.PDR.0000072784.55140.1E

Krause, M. F., Jäkel, C., Haberstroh, J., Schulte-Mönting, J., Leititis, J. U., and Orlowska-Volk, M. (2001). Alveolar recruitment promotes homogenous surfactant distribution in a piglet model of acute lung injury. Pediatr. Res. 50, 34-43. doi: 10.1203/00006450-200107000-00009

Krause, M. F., Wiemann, T., Reisner, A., Orlowska-Volk, M., Köhler, H., and Ankermann, T. (2005). Surfactant reduces extravascular lung water and invasion of polymorphonuclear leukocytes into the lung in a piglet model of airway lavage. Pulm. Pharmacol. Ther. 18, 129-139. doi: $10.1016 /$ j.pupt.2004.11.003

Kuipers, M. T., Aslami, H., Janczy, J. R., van der Sluijs, K. F., Vlaar, A. P. J., Wolthuis, E. K., et al. (2012). Ventilator-induced lung injury is mediated by the NLRP3 inflammasome. Anesthesiology 116, 1104-1115. doi: 10.1097/ALN.0b013e3182518bc0

Kumar, V. H., Patel, A., Swartz, D. D., Wang, H., Wynn, K. A., Nielsen, L. C., et al. (2010). Exposure to supplemental oxygen and its effects on oxidative stress and antioxidant enzyme activity in term newborn lambs. Pediatr. Res. 67, 66-71. doi: 10.1203/PDR.0b013e3181bf587f

Kunzmann, S., Collins, J. J., Kuypers, E., and Kramer, B. W. (2013). Thrown off balance: the effect of antenatal inflammation on the developing lung and immune system. Am. J. Obstet. Gynecol. 208, 429-437. doi: 10.1016/j.ajog.2013.01.008

Kuo, C.-Y. (2001). Endothelin-A receptor antagonist prevents neonatal pulmonary hypertension in meconium aspiration in piglets. J. Formos. Med. Assoc. $100,420-423$.

Kuo, C.-Y., and Chen, J.-Y. (1999). Effect of meconium aspiration on plasma endothelin-1 level and pulmonary hemodynamics in a piglet model. Biol. Neonate 76, 228-234. doi: 10.1159/000014163

Kuo, C. Y., and Liao, S. L. (2001). Hypoxemia inducing endothelin-1 secretion in meconium aspiration piglets. Acta Paediatr. Taiwan 42, 340-344.

Kyogashima, M., Ginsburg, V., and Krivan, H. C. (1989). Escherichia coli K99 binds to N-glycolylsialoparagloboside and N-glycolyl-GM3 found in piglet small intestine. Arch. Biochem. Biophys. 270, 391-397. doi: 10.1016/0003-9861(89)90042-8

Larios Mora, A., Detalle, L., van Geelen, A., Davis, M. S., Stohr, T., Gallup, J. M., et al. (2015). Kinetics of respiratory syncytial virus (RSV) Memphis strain 37 (M37) infection in the respiratory tract of newborn lambs as an RSV infection model for human infants. PLOS ONE 10:e0143580. doi: 10.1371/journal.pone. 0143580

Lee, M. K., Pryhuber, G. S., Schwarz, M. A., Smith, S. M., Pavlova, Z., and Sunday, M. E. (2005). Developmental regulation of $\mathrm{p} 66^{\text {Shc }}$ is altered by bronchopulmonary dysplasia in baboons and humans. Am. J. Respir. Crit. Care Med. 171, 1384-1394. doi: 10.1164/rccm.200406-776OC

Li, D., Ren, W., Jiang, Z., and Zhu, L. (2018). Regulation of the NLRP3 inflammasome and macrophage pyroptosis by the p38 MAPK signaling pathway in a mouse model of acute lung injury. Mol. Med. Rep. 18, 4399-4409. doi: $10.3892 / \mathrm{mmr} .2018 .9427$

Liao, J., Kapadia, V. S., Brown, L. S., Cheong, N., Longoria, C., Mija, D., et al. (2018). The NLRP3 inflammasome is critically involved in the development of bronchopulmonary dysplasia. Nat. Commun. 6:8977. doi: $10.1038 /$ ncomms 9977

Lin, C. H., Jeng, M. J., Kuo, B. I., and Kuo, Y. R. (2016). Effects of surfactant lavage combined with intratracheal budenoside instillation on meconium-injured piglet lungs. Pediatr. Crit. Care Med. 17, 287-295. doi: 10.1097/PCC.0000000000000729

Lin, C. H., Jeng, M. J., Yang, Y. C., Hsiao, Y. H., and Kou, Y. R. (2017). Comparison of different dosing strategies of intratracheally instilled budesonide on meconium injured piglet lungs. Pediatr. Pulmonol. 52, 891-899. doi: $10.1002 /$ ppul.23697

Lindenskov, P. H., Castellheim, A., Aamodt, G., and Saugstad, O. D. (2005). Meconium induced IL-8 production and intratracheal albumin alleviated lung injury in newborn pigs. Pediatr. Res. 57, 1-7. doi: 10.1203/01.PDR.0000153870.66197.D1

Lindenskov, P. H., Castellheim, A., Aamodt, G., Saugstad, O. D., and Mollnes, T. E. (2004). Complement activation reflects severity of meconium aspiration syndrome in newborn pigs. Pediatr. Res. 56, 810-817. doi: 10.1203/01.PDR.0000141983.32466.2A

Lindenskov, P. H., Castellheim, A., Saugstad, O. D., and Mollnes, T. E. (2015). Meconium aspiration syndrome: Possible pathophysiological mechanisms and future potential therapies. Neonatology 107, 225-230. doi: 10.1159/000369373

Liu, F., Li, W., Pauluhn, J., Trübel, H., and Wang, C. (2013). Rat models of acute lung injury: Exhaled nitric oxide as a sensitive, noninvasive real-time biomarker of prognosis and efficacy of intervention. Toxicology 310, 104-114. doi: 10.1016/j.tox.2013.05.016

Longo, C. A., Tyler, D., and Mallampalli, R. K. (1997). Sphingomyelin metabolism is developmentally regulated in rat lung. Am. J. Respir. Cell. Mol. Biol. 16, 605-612. doi: 10.1165/ajrcmb.16.5.9160843

Lotze, A., Mitchell, B. R., Bulas, D. I., Zola, E. M., Shalwitz, R. A., Gunkel, J. H., et al. (1998). Multicenter study of surfactant (beractant) use in the treatment of term infants with severe respiratory failure J. Pediatr. 132, 40-47. doi: 10.1016/S0022-3476(98)70482-2

Male, D. (2006). "Mechanisms of innate immunity," in Immunology, eds D. Male, J. Brostoff, D. B. Roth, and I. Roitt (Philadelphia, PA: Elsevier), 127-144. doi: 10.1016/B0-323-03399-7/50008-8

Matute-Bello, G., Frevert, C. W., and Martin, T. R. (2008). Animal models of acute lung injury. Am. J. Physiol. Lung Cell. Mol. Physiol. 295, L379-L399. doi: 10.1152/ajplung.00010.2008

Matute-Bello, G., Liles, W. C., Radella, I. I., F., Steinberg, K. P., Ruzinski, J. T., Jonas, M., et al. (1997). Neutrophil apoptosis in the acute respiratory distress syndrome. Am. J. Respir. Crit. Care Med. 156, 1969-1977. doi: $10.1164 /$ ajrccm.156.6.96-12081

Matute-Bello, G., and Martin, T. R. (2003). Science review: apoptosis in acute lung injury. Crit. Care 7, 355-358. doi: 10.1186/cc1861

Maus, U., Herold, S., Muth, H., Maus, R., Ermert, L., Ermert, M., et al. (2001). Monocytes recruited into the alveolar air space of mice show a monocytic phenotype but upregulate CD14. Am. J. Physiol. Lung Cell. Mol. Physiol. 280, L58-L68. doi: 10.1152/ajplung.2001.280.1.L58

Meduri, G. U., Golden, E., Freire, A. X., Taylor, E., Zaman, M., Carson, S. J., et al. (2007). Methylprednisolone infusion in early severe ARDS: results of a randomized controlled trial. Chest 131, 954-963. doi: 10.1378/chest. 06-2100

Meister, J., Balaraman, V., Ramirez, M., Uyehara, C. F. T., Killeen, J., Ku, T., et al. (2004). Lavage administration of dilute surfactant in a piglet model of meconium aspiration. Lung 182, 227-240. doi: 10.1007/s00408-004-2505-4 
Mercer, J. S., Erickson-Owens, D. A., Collins, J., Barcelos, M. O., Parker, A. B., and Padbury, J. F. (2017). Effects of delayed cord clamping on residual placental blood volume, hemoglobin and bilirubin levels in term infants: a randomized controlled trial. J. Perinatol. 37, 260-264. doi: 10.1038/jp.2016.222

Merz, U., Klosterhalfen, B., Häusler, M., Kellinghaus, M., Peschgens, T., and Hörnchen, H. (2002). Partial liquid ventilation reduces release of leukotriene B4 and interleukin-6 in bronchoalveolar lavage in surfactant-depleted newborn pigs. Pediatr. Res. 51, 183-189. doi: 10.1203/00006450-200202000-00010

Miles, J. R., Vallet, J. L., Ford, J. J., Freking, B. A., and Cushman, R. A. (2012). Contributions of the maternal uterine environment and piglet genotype on weaning survivability potential: I. Development of neonatal piglets after reciprocal embryo transfer between Meishan and White crossbred gilts. J. Anim. Sci. 90, 2181-2192. doi: 10.2527/jas.2011-4724

Mokra, D., Mikusiakova, L. T., Mikolka, P., Kosutova, P., Jurcek, M., Kolomaznik, M., et al. (2016). High-frequency jet ventilation against small-volume conventional mechanical ventilation in the rabbit models of neonatal acute lung injury. Adv. Exp. Med. Biol. 912, 83-93. doi: 10.1007/5584_2016_230

Möller, J. C., Schaible, T., Roll, C., Schiffmann, J.-H., Bindl, L., Schrod, L., et al. (2003). Treatment with bovine surfactant in severe acute respiratory distress syndrome in children: A randomized multicenter study. Intensive Care Med. 29, 437-446. doi: 10.1007/s00134-003-1650-1

Needham, D. M., Wozniak, A. W., Hough, C. L., Morris, P. E., Dinglas, V. D., Jackson, J. C., et al. (2014). Risk factors for physical impairment after acute lung injury in a national, multicenter study. Am. J. Respir. Crit. Care Med. 189, 1214-1224. doi: 10.1164/rccm.201401-0158OC

Numata, M., Chu, H. W., Dakhama, A., and Voelker, D. R. (2010). Pulmonary surfactant phosphatidylglycerol inhibits respiratory sncytial virus-induced inflammations and infection. Proc. Natl. Acad. Sci. U.S.A. 107, 320-325. doi: 10.1073/pnas.0909361107

Núnez, A., Sánchez-Cordón, P. J., Pedrera, M., Gómez-Villamandos, J. C., and Carrasco, L. (2018). Pulmonary intravascular macrophages regulate the pathogenetic mechanisms of pulmonary lesions during acute courses of classical swine fever. Trasnbound Emerg. Dis 65, 1885-1897. doi: $10.1111 /$ tbed.12970

Owen, L. S., Manley, B. J., Davis, P. G., and Doyle, L. W. (2017). The evolution of modern respiratory care for premature infants. Lancet 389, 1649-1659. doi: 10.1016/S0140-6736(17)30312-4

Palermo, S., Capra, E., Torremorell, M., Dolzan, M., Davoli, R., Haley, C. S., et al. (2009). Toll-like receptor 4 genetic diversity among pig populations. Anim. Genet. 40, 289-299. doi: 10.1111/j.1365-2052.2008.01833.x

Park, H. S., Liu, G., Liu, Q., and Zhou, Y. (2018). Swine influenza virus induces RIPK1/DRP1-mediated interleukin-1 beta production. Viruses 10:E419. doi: 10.3390/v10080419

Park, W. S., and Chang, Y. S. (2000). Effects of decreased cerebral perfusion pressure on cerebral hemodynamics, brain cell membrane function and energy metabolism during the early phase of experimental Escherichia coli meningitis in the newborn piglet. J. Korean Med. Sci. 15, 203-210. doi: $10.3346 / \mathrm{jkms}$.2000.15.2.203

Parker, R. O., and Aherne, F. X. (1980). Serum and urine concentrations of protein, urea, sodium, and potassium during the immediate postnatal period of the suckling pig. Biol. Neonate 38, 11-15. doi: 10.1159/000241320

Petersen, Y. M., Hartmann, B., Holst, J. J., Le Huerou-Luron, I., Bjornvad, C. R., and Sangild, P. T. (2003). Introduction of enteral food increases plasma GLP-2 and decreases GLP-2 receptor mRNA abundance during pig development. J. Nutr. 133, 1781-1786. doi: 10.1093/jn/133. 6.1781

Pires-Neto, R. C., Morales, M. M., Lancas, T., Inforsato, N., Duarte, M. I., Amato, M. B., et al. (2013). Expression of acute-phase cytokines, surfactant proteins, and epithelial apoptosis in small airways of human acute respiratory distress syndrome. J. Crit. Care 28, 111.e9-111.e15. doi: 10.1016/j.jcrc.2012.05.013

Polglase, G. R., Hillman, N. H., Ball, M. K., Kramer, B. W., Kallapur, S. G., Jobe, A. H., et al. (2008). Lung and systematic inflammation in preterm lambs on continuous positive airway pressure or conventional ventilation. Pediatr. Res. 65, 67-71. doi: 10.1203/PDR.0b013e318189487e

Preuß, S., Omam, F. D., Scheiermann, J., Stadelmann, S., Winoto-Morbach, S., von Bismarck, P., et al. (2012a). Topical application of phosphatidyl-inositol3,5-bisphosphate for acute lung injury in neonatal swine. J. Cell. Mol. Med. 16, 2813-2826. doi: 10.1111/j.1582-4934.2012.01618.x
Preuß, S., Scheiermann, J., Stadelmann, S., Omam, F. D., Winoto-Morbach, S., Lex, D., et al. (2014). 18:1/18:1-dioleoyl-phosphatidylglycerol prevents alveolar epithelial apoptosis and profibrotic stimulus in a neonatal piglet model of acute respiratory distress syndrome. Pulm. Pharmacol. Ther. 28, 25-34. doi: 10.1016/j.pupt.2013.10.002

Preuß, S., Stadelmann, S., Omam, F. D., Scheiermann, J., Winoto-Morbach, S., von Bismarck, P., et al. (2012b). Inositol-trisphosphate reduces alveolar apoptosis and pulmonary edema in neonatal lung injury. Am. J. Respir. Cell. Mol. Biol. 47, 158-169. doi: 10.1165/rcmb.2011-0262OC

Qin, X., Fu, W., Zhao, Y., Meng, Q., You, C., and Yu, Q. (2013). Ultrastructural study of alveolar epithelial type II cells by high frequency oscillatory ventilation. Biomed. Res. Int. 2013, 1-5. doi: 10.1155/2013/240659

Rauvala, H., and Hallman, M. (1984). Glycolipid accumulation in bronchoalveolar space in adult respiratory distress syndrome. J. Lipid Res. 25, 1257-1262.

Renesme, L., Elleau, C., Nolent, P., Fayon, M., Marthan, R., and Dumas de la Roque, E. (2013). Effect of high-frequency oscillation and percussion versus conventional ventilation in a piglet model of meconium aspiration. Pediatr. Pulmonol. 48, 257-264. doi: 10.1002/ppul.22590

Riedler, J., Grigg, J., Stone, C., Tauro, G., and Robertson, C. F. (1995). Bronchoalveolar lavage cellularity in halthy children. Am. J. Respir. Crit. Care Med. 152, 163-168. doi: 10.1164/ajrccm.152.1.7599817

Ryhammer, P., Pedersen, M., Ringgaard, S., and Ravn, H. (2007). Regional pulmonary perfusion using model-free analysis of contrast-enhanced MRI in meconium-aspirated piglets. J. Magn. Reson. Imaging 26, 296-303. doi: 10.1002/jmri.20975

Salvesen, B., Curstedt, T., Mollnes, T. E., and Saugstad, O. D. (2014). Effects of natural versus synthetic surfactant with SP-B and SP-C analogs in a porcine model of meconium aspiration syndrome. Neonatology 105, 128-135. doi: $10.1159 / 000356065$

Salvesen, B., Mollnes, T. E., and Saugstad, O. D. (2008). Albumin lavage does not improve the outcome of meconium aspiration syndrome. J. Matern. Fetal Neonatal Med. 21, 719-725. doi: 10.1080/14767050802255561

Salvesen, B., Stenvik, J., Rossetti, C., Saugstad, O. D., Espevik, T., and Mollnes, T. E. (2010). Meconium-induced release of cytokines is mediated by the TLR4/MD2 complex in a CD14-dependent manner. Mol. Immunol. 47, 1226-1234. doi: 10.1016/j.molimm.2009.12.015

Saugstad, O. D., Tollofsrud, P. A., Lindenskov, P., and Drevon, C. A. (2008). Toxic effects of different meconium fractions on lung function: new therapeutic strategies for meconium aspiration syndrome? J. Perinatol. 28, S113-S115. doi: $10.1038 /$ jp.2008.151

Schneberger, D., Aharonson-Raz, K., and Singh, B. (2012). Pulmonary intravascular macrophages and lung health: what are we missing? Am. J. Physiol. Lung Cell Mol. Physiol. 302, L498-L503. doi: 10.1152/ajplung.00322.2011

Schouten, L. R., Schultz, M. J., van Kaam, A. H., Juffermans, N. P., Bos, A. P., and Wösten-van Asperen, R. M. (2015). Association between maturation and aging and pulmonary responses in animal models of lung injury. A systemetic review. Anesthesiology 123, 389-408. doi: 10.1097/ALN.0000000000000687

Schouten, L. R., van Kaam, A. H., Kohse, F., Veltkamp, F., Bos, L. D., de Beer, F. M., et al. (2019). Age-dependent differences in pulmonary host responses in ARDS: A prospective observational cohort study. Ann. Intensive Care 14:55 doi: 10.1186/s13613-019-0529-4

Schwingshackl, A., Kimura, D., Rovnaghi, C. R., Saravia, J. S., Cormier, S. A., Teng, B., et al. (2016). Regulation of inflammatory biomarkers by intravenous methylprednisolone in pediatric ARDS patients: results from a double-blind, placebo-controlled randomized pilot trial. Cytokine 77, 63-71. doi: 10.1016/j.cyto.2015.10.007

Seeger, W., Grube, C., Günther, A., and Schmidt, R. (1993). Surfactant inhibition by plasma proteins: differential sensitivity of various surfactant preparations. Eur. Respir. J. 6, 971-977.

Shekerdemian, L. S., Penny, D. J., Ryhammer, P. K., Reader, J. A., and Ravn, H. B. (2004). Endothelin-A receptor blockade and inhaled nitric oxide in a porcine model of meconium aspiration syndrome. Pediatr. Res. 56, 353-358. doi: 10.1203/01.PDR.0000134257.20214.57

Silvera, F. E., Blasina, M. F., Vaamonde, L., Tellechea, S., Godoy, C., Zabala, S. et al. (2011). Sildenafil prevents the increase of extravascular lung water and pulmonary hypertension after meconium aspiration in newborn piglets. Braz. J. Med. Biol. Res. 44, 778-785. doi: 10.1590/S0100-879X2011007500085 
Sly, P. D., Nicholls, P. K., Berry, L. J., Hantos, Z., and Cannizzaro, V. (2013). High tidal volume ventilation does not exacerbate acid-induced lung injury in infant rats. Respir. Physiol. Neurobiol. 189, 129-135. doi: 10.1016/j.resp.2013.07.013

Sood, S. L., Balaraman, V., Finn, K. C., Britton, B., Uyehara, C. F. T., and Easa, D. (1996a). Exogenous surfactants in a piglet model of acute respiratory distress syndrome. Am. J. Respir. Crit. Care Med. 153, 820-828. doi: 10.1164/ajrccm.153.2.8564138

Sood, S. L., Balaraman, V., Finn, K. C., Wilkerson, S. Y., Mundie, T. G., and Easa, D. (1996b). Exogenous surfactant decreases oxygenation in Escherichia coli endotoxin-treated neonatal piglets. Pediatr. Pulmonol. 22, 376-386. doi: 10. 1002/(SICI)1099-0496(199612)22:6<376::AID-PPUL6>3.0.CO;2-H

Spengler, D., Winoto-Morbach, S., Kupsch, S., Vock, C., Blöchle, K., Frank, S., et al. (2018). Novel therapeutic roles for surfactant-inositols and -phosphatidylglycerols in a neonatal piglet ARDS model: a translational study. Am. J. Physiol. Lung Cell. Mol. Physiol. 314, L32-L53. doi: 10.1152/ajplung.00128.2017

Spragg, R. G., Lewis, J. F., Walmrath, H.-D., Johannigman, J., Bellingan, G., Laterre, P.-F., et al. (2004). Effect of recombinant surfactant protein-C based surfactant on the acute respiratory distress syndrome. N. Engl. J. Med. 351, 884-892. doi: 10.1056/NEJMoa033181

Standaert, T. A., Wilham, B. E., Mayock, D. E., Watchko, J. F., Gibson, R. L., and Woodrum, D. E. (1991). Respiratory mechanics of the piglet during the first month of life. Pediatr. Pulmonol. 11, 294-301. doi: 10.1002/ppul.1950110405

Steinberg, K. P., Hudson, L. D., Goodman, R. B., Hough, C. L., Lanken, P. N., Hyzy, R., et al. (2006). Efficacy and safety of corticosteroids for persistent acute respiratory distress syndrome. N. Engl. J. Med. 354, 1671-1684. doi: 10.1056/NEJMoa051693

Sundell, H. W., Harris, T. R., Cannon, J. R., Lindstrom, D. P., Green, R., Rojas, J., et al. (1987). Lung water and vascular permeability-surface area in premature newborn lambs with hyaline membrane disease. Circ. Res. 60, 923-932. doi: 10.1161/01.RES.60.6.923

Székely, A., Breuer, T., Sápi, E., Székely, E., Szatmári, A., Tóth, M., et al. (2011). Transpulmonary thermodilution in neonates undergoing arterial swith surgery. Pediatr. Cardiol. 32, 125-130. doi: 10.1007/s00246-010-9828-0

Taut, F. J., Rippin, G., Schenk, P., Findlay, G., Wurst, W., Häfner, D., et al. (2008). A search for subgroups of patients with ARDS who may benefit from surfactant replacement therapy: a pooled analysis of five studies with recombinant surfactant protein-C surfactant (Venticute). Chest 134, 724-732. doi: 10.1378/chest.08-0362

Teichgräber, V., Ulrich, M., Endlich, N., Riethmüller, J., Wilker, B., de OliveiraMunding, C. C., et al. (2008). Ceramide accumulation mediates inflammation, cell death and infection susceptibility in cystic fibrosis. Nat. Med. 14, 382-391. doi: $10.1038 / \mathrm{nm} 1748$

Thomas, A. M., Schjalm, C., Nilsson, P. H., Lindenskov, P. H. H., Rortveit, R., Solberg, R., et al. (2018). Combined inhibition of C5 and CD14 attenuates systemic inflammation in a piglet model of meconium aspiration syndrome. Neonatology 113, 322-330. doi: 10.1159/000486542

Tibboel, J., Joza, S., Reiss, I., de Jongste, J. C., and Post, M. (2013). Amelioration of hyperoxia-induced lung injury using a sphingolipidbased intervention. Eur. Respir. J. 42, 776-784. doi: 10.1183/09031936. 00092212

Todd, D. A., Marsh, M. J., George, A., Henderson, N. G., Barr, H., Sebastian, S., et al. (2010). Surfactant phospholipids, surfactant proteins, and inflammatory markers of acute lung injury in children. Pediatr. Crit. Care Med. 11, 82-91. doi: 10.1097/PCC.0b013e3181ae5a4c

Tølløfsrud, P. A., Medbo, S., Solas, A. B., Robertson, B., Speer, C. P., Seidenspinner, S., et al. (2004). Intratracheal albumin reduces interleukin-8 in tracheobronchial aspirates in piglets after meconium aspiration. J. Perinat. Med. 32, 78-83. doi: 10.1515/JPM.2004. 015

Tølløfsrud, P. A., Medbro, S., Solas, A. B., Drevon, C. A., and Saugstad, O. D. (2002). Albumin mixed with meconium attenuates pulmonary dysfunction in a newborn piglet model with meconium aspiration. Pediatr. Res. 52, 545-553. doi: 10.1203/00006450-200210000-00014

Tollofsrud, P. A., Solas, A. B., and Saugstad, O. D. (2001). Newborn piglets with meconium aspiration resuscitated with room air or $100 \%$ oxygen. Pediatr. Res. 50, 423-429. doi: 10.1203/00006450-200109000-00020
Trindade, O., Goldberg, R. N., Bancalari, E., Dickstein, P., Ellison, J., and Gerhardt, T. (1985). Conventional vs high-frequency jet ventilation in a piglet model of meconium aspiration: Comparison of pulmonary and hemodynamic effects. $J$. Pediatr. 107, 115-120. doi: 10.1016/S0022-3476(85)80631-4

Trummer-Menzi, E., Gremlich, S., Schittny, J. C., Dénervaud, V., Stampanoni, M., Post, M., et al. (2012). Evolution of gene expression changes in newborn rats after mechanical ventilation with reversible intubation. Pediatr. Pulmonol. 47, 1204-1214.

van Ierland, Y., and de Beaufort, A. J. (2009). Why does meconium cause meconium aspiration syndrome? Current concepts of MAS pathophysiology. Early Hum. Dev. 85, 617-620. doi: 10.1016/j.earlhumdev.2009.09.009

van Kaam, A., Haitsma, J. J., de Jaegere, A., van Aalderen, W. M., Kok, J. H., and Lachmann, B. (2004a). Open lung ventilation improves gas exchange and attenuates secondary lung injury in a piglet model of meconium aspiration. Crit. Care Med. 32, 443-449. doi: 10.1097/01.CCM.0000104952.61111.49

van Kaam, A., Lachmann, R. A., Herting, E., de Jaegere, A., van Iwaarden, F., Noorduyn, L. A., et al. (2004b). Reducing atelectasis attenuates bacterial growth and translocation in experimental pneumonia. Am. J. Respir. Crit. Care Med. 169, 1046-1053. doi: 10.1164/rccm.200312-1779OC

van Kaam, A. H., de Jaegere, A., Haitsma, J. J., van Aalderen, W. M., Kok, J. H., and Lachmann, B. (2003a). Positive pressure ventilation with the open lung concept optimizes gas exchange and reduces ventilator-induced lung injury in newborn piglets. Pediatr. Res. 53, 245-253. doi: 10.1203/01.PDR.0000047520.44168.22

van Kaam, A. H., Dik, W. A., Haitsma, J. J., de Jaegere, A., Naber, B. A., van Aalderen, W. M., et al. (2003b). Application of the open-lung concept during positive-pressure ventilation reduces pulmonary inflammation in newborn piglets. Biol. Neonate 83, 273-280. doi: 10.1159/000069482

van Kaam, A. H., Lutter, R., Lachmann, R. A., Haitsma, J. J., Herting, E., Snoek, M., et al. (2005). Effect of ventilation strategy and surfactant on inflammation in experimental pneumonia. Eur. Respir. J. 26, 112-117. doi: 10.1183/09031936.05.00144504

van Veenendaal, M. B., van Kaam, A. H., Haitsma, J. J., Lutter, R., and Lachmann, B. (2006). Open lung ventilation preserves the response to delayed surfactant treatment in surfactant-deficient newborn piglets. Crit. Care Med. 34, 2827-2834. doi: 10.1097/01.CCM.0000243794.09377.96

von Bismarck, P., García Wistädt, C.-F., Klemm, K., Winoto-Morbach, S., Uhlig, U., Schütze, S., et al. (2008). Improved pulmonary function by acid sphingomyelinase inhibition in a newborn piglet lavage model. Am. J. Respir. Crit. Care Med. 177, 1233-1241. doi: 10.1164/rccm.200705-752OC

von Bismarck, P., Klemm, K., García Wistädt, C.-F., Winoto-Morbach, S., Schütze, S., and Krause, M. F. (2009). Selective NF-inhibition, but not dexamethasone, decreases acute lung injury in a newborn piglet airway inflammation model. Pulm. Pharmacol. Ther. 22, 297-304. doi: 10.1016/j.pupt.2009. 02.002

von Bismarck, P., Klemm, K., García Wistädt, C.-F., Winoto-Morbach, S., Uhlig, U., Schütze, S., et al. (2007). Surfactant "fortification" by topical inhibition of nuclear factor-kappaB activity in a newborn piglet lavage model. Crit. Care Med. 35, 2309-2318. doi: 10.1097/01.CCM.0000281472.47067.45

von der Hardt, K., Schoof, E., Kandler, M. A., Dötsch, J., and Rascher, W. (2002). Aerosolized perfluorocarbon suppresses early pulmonary inflammatory response in a surfactant-depleted piglet model. Pediatr. Res. 51, 177-182. doi: 10.1203/00006450-200202000-00009

Voss, L. J., Bolton, D. P. G., Galland, B. C., and Taylor, B. J. (2004). Endotoxin effects on markers of autonomic nervous system function in the piglet: implications for SIDS. Biol. Neonate 86, 39-47. doi: 10.1159/000077452

Wang, H., Xu, L., Zhao, J., Wang, D., Guo, R., Wang, J., et al. (2014). Regulatory mechanisms of pyrrolidine dithiocarbamate is mediated by nuclear factorkappaB and inhibits neutrophil accumulation in ARDS mice. Exp. Ther. Med. 8, 614-622. doi: 10.3892/etm.2014.1738

Wang, P. W., Jeng, M. J., Wang, L. S., Fang, L. J., and Soong, W. J. (2010). Surfactant lavage decreases systemic interleukin-1 beta production in meconium aspiration syndrome. Pediatr. Int. 52, 432-437. doi: 10.1111/j.1442-200X.2009.03007.x

Wang, X., Zhang, L., and Sun, B. (2016). Neonatal type II alveolar epithelial cell transplant facilitates lung reparation in piglets with acute lung injury and extracorporal life support. Pediatr. Crit. Care Med. 17, e182-e192. doi: 10.1097/PCC.0000000000000667 
Willson, D. F., Thomas, N. J., Markovitz, B. P., Bauman, L. A., DiCarlo, J. V., Pon, S., et al. (2005). Effect of exogenous surfactant (calfactant) in pediatric acute lung injury. JAMA 293, 470-476. doi: 10.1001/jama.293.4.470

Willson, D. F., Truwit, J. D., Conaway, M. R., Traul, C. S., and Egan, E. E. (2015). The adult calfactant in acute respiratory distress syndrome trial. Chest 148, 356-364. doi: 10.1378/chest.14-1139

Wiswell, T. E., Peabody, S. S., Davis, J. M., Slayter, M. V., Bent, R. C., and Merritt, T. A. (1994). Surfactant therapy and high-frequency jet ventilation in the management of a piglet model of the meconium aspiration syndrome. Pediatr. Res. 36, 494-500. doi: 10.1203/00006450-199410000-00015

Wolkoff, L. I., Levine, C. R., Koo, H. C., LaGamma, E. F., Pollack, S., Chester, D., et al. (2002). Effects of granulocyte colony-stimulating factor on hyperoxia-induced lung injury in newborn piglets. Lung 180, 229-239. doi: $10.1007 / \mathrm{s} 004080000097$

Wright, J. R. (2003). Pulmonary surfactant: a front line of lung host defense. J. Clin. Invest. 111, 1453-1455. doi: 10.1172/JCI200318650

Wu, Q., Chong, L., Shao, Y., Chen, S., and Li, C. (2019). Lipoxin A4 reduces hyperoxia-induced lung injury in neonatal rats through PINK1 signaling pathway. Int. Immunopharmacol. 73, 414-423. doi: 10.1016/j.intimp.2019.05.046

Yang, C.-F., Jeng, M.-J., Soong, W.-J., Lee, Y.-S., Tsao, P.-C., and Tang, R.-B. (2010). Acute pathophysiological effects of intratracheal instillation of budenoside and exogenous surfactant in a neonatal surfactant-depleted piglet model. Pediatr. Neonatol. 51, 219-226. doi: 10.1016/S1875-9572(10)60042-3

Yang, C.-F., Lin, C.-H., Chiou, S.-Y., Yang, Y.-C., Tsao, P.-C., Lee, Y.-S., et al. (2013). Intratracheal budenoside supplementation in addition to surfactant improves pulmonary outcome in surfactant-depleted newborn piglets. Pediatr. Pulmonol. 48, 151-159.

Yang, Q., Li, Z. Q., Lan, H. B., Xiong, S. S., Wang, S. S., and Yan, C. S. (2017). Research of the biomarkers in pulmonary and extrapulmonary acute respiratory distress syndrome. Zhonghua Yi Xue Za Zhi. 97, 2023-2027. doi: 10.3760/cma.j.issn.0376-2491.2017.26.002

Yeganeh, B., Lee, J., Bilodeau, C., Lok, I., Ermini, L., Ackerley, C., et al. (2018). Acid sphingomyelinase inhibition attenuates cell death in mechanically- ventilated newborn rat lung. Am. J. Respir. Crit. Care Med. 199, 760-772. doi: 10.1164/rccm.201803-0583OC

Yehya, N., Servaes, S., Thomas, N. J., Nadkarni, V. M., and Srinivasan, V. (2015). Corticosteroid exposure in pediatric acute respiratory distress syndrome. Intensive Care Med. 41, 1658-1666. doi: 10.1007/s00134-015-3953-4

Yoder, B. A., Siler-Khodr, T., Winter, V. T., and Coalson, J. J. (2000). High frequency oscillatory ventilation: effects on lung function, mechanics, and airway cytokines in the immature baboon model for neonatal chronic lung disease. Am. J. Respir. Crit. Care Med. 162, 1867-1876. doi: 10.1164/ajrccm.162.5.9912145

Youssef, J. A., Thibeault, D. W., Rezaiekhaligh, M. H., Mabry, S. M., Norberg, M. I., and Truog, W. E. (1999). Influence of inhaled nitric oxide and hyperoxia on $\mathrm{Na}, \mathrm{K}-\mathrm{ATPase}$ expression and lung edema in newborn piglets. Biol. Neonate 75 , 199-209. doi: 10.1159/000014096

Zhu, Y., Guo, C., Cao, L., Gong, X., Wang, C., and Sun, B. (2005). Different effects of surfactant and inhaled nitric oxide in modulation of inflammatory injury in ventilated piglet lungs. Pulm. Pharmacol. Ther. 18, 303-313. doi: 10.1016/j.pupt.2005.01.005

Zinter, M. S., Spicer, A., Orwoll, B. O., Alkhouli, M., Dvorak, C. C., Calfee, C. S., et al. (2016). Plasma angiopoietin-2 outperforms other markers of endothelial injury in prognosticating pediatric ARDS mortality. Am. J. Physiol. Lung Cell. Mol. Physiol. 310, L224-L231. doi: 10.1152/ajplung.00336.2015

Conflict of Interest: The authors declare that the research was conducted in the absence of any commercial or financial relationships that could be construed as a potential conflict of interest.

Copyright (c) 2019 Spengler, Rintz and Krause. This is an open-access article distributed under the terms of the Creative Commons Attribution License (CC BY).

The use, distribution or reproduction in other forums is permitted, provided the original author(s) and the copyright owner(s) are credited and that the original publication in this journal is cited, in accordance with accepted academic practice. No use, distribution or reproduction is permitted which does not comply with these terms. 